Assessment of the Effects and impacts Caused by Hurricane Irma The Bahamas 

Assessment of the Effects and impacts Caused by Hurricane Irma

\section{The Bahamas}

2017 

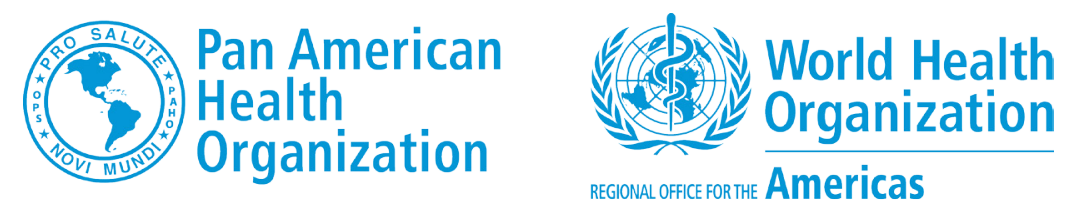

\author{
Economic Commission for Latin America and the Caribbean \\ Omar Bello \\ Mission Coordinator \\ Michael Hendrickson \\ Macroeconomics \\ Blaine Marcano \\ Education \\ Machel Pantin \\ Research Assistant
}

\title{
Pan American Health Organization
}

Gustavo Mery

Health

\section{Sector Specialists}

Carlos Espiga

Housing \& Water and Sanitation

Franklin Espiga

Roads, Ports and Air

Mauricio González

Description of the Event, Affected Population

Adrían Flores

Disaster Risk Reduction

Francisco Ibarra

Tourism, Fisheries

Salvador Marconi

National Accounts

Robert Williams

Power \& Telecommunications

\section{Inter-American Development Bank}

Florencia Attademo-Hirt

Country Representative

Michael Nelson

Chief of Operations

\section{Editorial Production}


List of Table

List of Figures 11

List of Images 11

List of Acronyms $\quad 13$

Executive Summary $\quad 15$

$\begin{array}{lr}\text { Introduction } & 17\end{array}$

Description of the Event $\quad 25$

Hurricane Irma in The Bahamas $\quad 27$

Weather-related Events in The Bahamas $\quad 34$

1. Hurricane Joaquin $\quad 35$

2. Hurricane Mathew 36

$\begin{array}{ll}\text { Affected Population } & 39\end{array}$

Introduction 40

1. The Evacuation to Nassau 44

2. Affected Islands 41

Demographics 42

3. Affected Population 44

PART I: ASSESSMENT OF IMPACTS AND EFFECTS 48

$\begin{array}{lr}\text { SOCIAL SECTORS } & 49\end{array}$

Housing and Public Buildings 51

Introduction $\quad 51$

1. Baseline information 51

2. Damage 52

3. Losses 55

4. Additional Costs $\quad 55$

$\begin{array}{ll}\text { Education } & 56\end{array}$

Introduction $\quad 56$

1. Baseline Information 57

2. Damage 58

3. Losses 60

4. Additional Costs 62

Health 63

Introduction 63

1. Baseline Information 63

2. Damage 65 
3. Losses 67

4. Additional Costs 68

INFRASTRUCTURE SECTORS

Roads, Airports, Ports and Other Infrastructure 71

Introduction $\quad 71$

1. Baseline Information $\quad 71$

2. Damage 74

3. Losses 82

4. Additional Costs 82

Telecommunications $\quad 84$

Introduction $\quad 84$

1. Baseline Information 85

2. Damage 86

3. Losses 87

3. Additional Costs 87

$\begin{array}{lr}\text { Power } & 88\end{array}$

Introduction 88

1. Baseline information 89

2. Damage 89

3. Losses 91

4. Additional costs $\quad 91$

Water and Sanitation $\quad 92$

Introduction $\quad 92$

1. Baseline information 93

2. Damage 97

3. Losses 94

4. Additional Costs 94

PRODUCTIVE SECTORS 96

$\begin{array}{lr}\text { Tourism } & 97\end{array}$

Introduction $\quad 97$ 
1. Baseline Information 97

2. Damage 98

3. Losses 99

4. Additional Costs 103

$\begin{array}{ll}\text { Fisheries } & 104\end{array}$

Introduction 104

1. Baseline Information $\quad 104$

2. Damage 105

3. Losses 106

$\begin{array}{lr}\text { MACROECONOMIC SECTOR } & 108\end{array}$

Assessment of the Impact of Hurricane Irma on the

Family Islands in The Bahamas 109

$\begin{array}{ll}\text { Introduction } & 109\end{array}$

- Performance of the economy during the first

half of 2017 before Hurricane Irma 109

- The Fiscal Situation 109

- Monetary Developments 110

- The Balance of Payments 110

Impact of Hurricane Irma on The Bahamas 111

- Impact on GDP 111

- Impact on inflation 112

Fiscal Impact $\quad 112$

- Monetary Developments 115

- The Impact on the Balance of Payments 115

Macroeconomic Challenges in the Context of the Hurricane 117

$\begin{array}{ll}\text { PART II: RECOMMENDATIONS } & 121\end{array}$

$\begin{array}{ll}\text { Recommendations for a resilient reconstruction } & 123\end{array}$

Introduction 123

Pillar 1: Risk identification 124

Pillar 2: Risk reduction $\quad 126$

Pillar 3: Preparedness 131

Pillar 4: Financial protection 137

Pillar 5: Resilient Recovery 140

$\begin{array}{lr}\text { References } & 149\end{array}$ 



\section{List of Table}

Table 1- Sectors and Subsectors of ECLAC-IDB's Assessment 18

Table 2- Summary of Effects of Hurricane Irma (\$) 19

Table 3- Sectorial Effects of Hurricane Irma $\quad 20$

Table 4- Tropical Storms and Hurricanes in The Bahamas (1990-2017) 34

Table 5- Evacuated Flights by Island, Company and Number of Persons Evacuated 40

Table 6- Demographics of Affected Islands 43

Table 7- Disabled Population on Affected Islands 43

Table 8- Evacuated Population to Nassau and Population in Shelters 44

Table 9- Population in Shelters for all The Bahamas 45

Table 10- Dwellings by Household Income and by Island 52

Table 11- Summary of Damage in the Housing and Public Buildings Sector 52

Table 12- Summary of Damage in the Housing and Public Buildings Sector by island 53

Table 13- Levels of Damage to Housing by Island 54

Table 14- Summary of Losses in the Housing and Public Buildings Sector 55

Table 15- Summary of Additional Costs in the Housing and Public Buildings Sector 55

Table 16- Total Damage, Losses and Additional Costs 56

Table 17- Categories of Schools in The Bahamas $\quad 57$

Table 18- Facilities and Students 58

Table 19- Estimated Damage to Education Facilities by Island 59

Table 20-School Closures Beyond 12 September $2017 \quad 60$

Table 21- Summary of Losses in the Education Sector $\quad 61$

Table 22- Summary of Additional Costs in the Education Sector 62

Table 23- Distribution of public clinics in The Bahamas by island $\quad 64$

Table 24- Public hospitals in The Bahamas. 64

Table 25- Summary of damage to public health clinics by Hurricane Irma 65

Table 26- Damage Score Scale* 66

Table 27- Summary of damage in public health facilities - Hospitals and others 66

Table 28- Damage in public health facilities attributed to Hurricane Irma 67

Table 29- Losses to disruption in health services due to Hurricane Irma 67

Table 30- Additional costs associated with emergency response 68

Table 31- Airport Runways on Affected Islands 73

Table 32- Estimated Total Damage, Losses, and Additional Costs $\quad 74$

Table 33- Damage to Roads $\quad 77$

Table 34- Damage to Seawalls $\quad 78$

$\begin{array}{ll}\text { Table 35- Damage to Airports } & 79\end{array}$

Table 36- Damage to Docks 80

Table 37- Summary of Losses in the Roads, Airports 82

Table 38- Additional Costs in the Roads, Airports, Ports and Other infraestructure Sector 83

Table 39- Summary of Damage, Losses, and Additional Costs in the Telecomunications Sector 84

Table 40- Damage in the Telecommunications Sector 87

Table 41- Losses in the Telecommunications Sector $\quad 87$

Table 42- Additional Costs in the Telecommunications Sector 87

Table 43- Damage, Losses, and Additional Cost in the Power Sector, by Island 88

Table 44- Damage in the Power Sector 90

Table 45- Losses in the Power Sector $\quad 91$

Table 46- Additional Costs in the Power Sector $\quad 91$

Table 47- Water Supply in Private Dwellings, in The Bahamas 92

Table 48- Type of Sewerage System by Island 93

Table 49- Summary of Damage in the Water Sector 93

Table 50- Summary of Losses in the Water and Sanitation Sector 94

Table 51- Additional Costs in the Water and Sanitation Sector 95

Table 52- Summary of Damage in the Tourism Sector 99

Table 53- Total Losses in the Tourism Sector by Type of Visitor 100

Table 54- Total Losses in Tourism by Type of Expenditure 101

Table 55- New Providence Losses by Type of Visitor 102

Table 56- Grand Bahama Losses by Type of Visitor 102

Table 57- Out Islands losses by Type of Visitor $\quad 103$

Table 58- Summary of Additional Costs in the Tourism Sector $\quad 103$

Table 59- Summary of Damage in the Fisheries Sector $\quad 105$

Table 60- Damage by Island 106

Table 61- Total Losses by Catch 106

Table 62- Impact of Hurricane Government Fiscal Operations 114

Table 63- Impact of Hurricane Irma on the Balance of Payments 117

Table 64- Pillars of Action for Disaster Risk Reduction 123

Table 65- Materials and techniques to protect shingles $\quad 129$ 



\section{List of Figures}

Figure 1- Path of Hurricane Irma across the Atlantic 26

Figure 2- Path of Hurricane Irma in the Northern Caribbean and Western Atlantic 26

Figure 3- Force wind swaths of Irma - Salina Point - Acklins 29

Figure 4- Force wind swaths of Irma -Salina Point - Bimini 30

Figure 5- Force wind swaths of Irma - Grand Bahama - Free Port 31

Figure 6- Force wind swaths of Irma - Great Inagua (Inagua) 32

Figure 7- Force wind swaths of Irma - Ragged Island 33

Figure 8- Trajectory of Hurricane Joaquin, from 28 September to 7 October $2015 \quad 36$

Figure 9- Trajectory of Hurricane Mathew, from 28 September to 9 October 2016

Figure 10- Distribution of people evacuated to Nassau according to each island 41

Figure 11- Income and Losses $\quad 100$

Figure 12- Fiscal balances before and after Hurricane Irma $\quad 115$

Figure 13- Balance of payments current account balance before and after Hurricane Irma 116

\section{List of Images}

Image 1- Pavement structure and draining problems, in Acklins and Great Inagua Islands 72 Image 2- Ragged Island Airport Terminal / Resilient Prefabricated Solution 73 Image 3- Resort World Marina (Bimini) Image 4- Damage on private dock facility at Bimini $\quad 75$ Image 5- Damage at Resort World Private Marina (Bimini) 76 Image 6- Dock in Great Inagua $\quad 76$ Image 7- Damage in roads at Salina Point, Acklins Island 77 Image 8- Seawall Damage Inspected in Great Inagua $\quad 78$ Image 9- Damage in the Ragged Island Airport Runway $\quad 79$ Image 10- Minor damage at Great Inagua and Acklins Islands Airports 80 Image 11- Collapse of Ragged Island airport terminal 80 Image 12- Ragged Island Fishing Dock Damage 81 Image 13- Styrofoam floating in the ocean in Bimini in September. 81 Image 14- Brush fire caused by contact between vegetation and power lines 91 Image 15- Damage in RO water plant- Ragged Island 94 Image 16- Antennas connected to a tower at one point vs. antennas 132 Image 17- Damage to floating docks 134 Image 18- Road elevation 144 Image 19- Airport infrastructure: inadequate vs. resilient design $\quad 144$ Image 20- Mathew Town Dock Construction $\quad 145$ 



\section{List of Acronyms}

$\begin{array}{ll}\text { AXP } & \text { Acklins Airport } \\ \text { BDSNi } & \text { Bahamas Domestic Submarine Network } \\ \text { BEC } & \text { The Bahamas Electric Company } \\ \text { BIM } & \text { Bimini Airport } \\ \text { BPL } & \text { Bahamas Power and Light } \\ \text { BTC } & \text { The Bahamas Telecommunications Company } \\ \text { CCRIF } & \text { Caribbean Catastrophic Risk Insurance Facility } \\ \text { DALA } & \text { Damage and Loss Assessment } \\ \text { DCT } & \text { Ragged Island Airport } \\ \text { DOE } & \text { Department of Energy } \\ \text { ECLAC } & \text { Economic Commission of Latin America and the Caribbean } \\ \text { FDI } & \text { Foreign Direct Investment } \\ \text { FEMA } & \text { Federal Emergency Management Agency } \\ \text { FISIM } & \text { Financial Intermediation Services Indirectly Measured } \\ \text { FTTH } & \text { Fiber-to-the-home } \\ \text { GBPC } & \text { Grand Bahama Power Company } \\ \text { GDP } & \text { Gross Domestic Product } \\ \text { GFDRR } & \text { Global Framework on Disaster Risk Reduction } \\ \text { ICZMP } & \text { Integrated Coastal Zone Management Plan } \\ \text { IDB } & \text { Inter-American Development Bank } \\ \text { IGA } & \text { Inagua Airport } \\ \text { IMF } & \text { International Monetary Fund } \\ \text { IPP } & \text { Independent Power Producer } \\ \text { IPTV } & \text { Internet Protocol Television } \\ \text { ISIC } & \text { International Standard Industrial Classification } \\ \text { NEMA } & \text { National Emergency Management Agency } \\ \text { NEOC } & \text { National Emergency Operation Center } \\ \text { NHC } & \text { National Hurricane Center } \\ \text { NOAA } & \text { National Oceanic and Atmospheric Administration } \\ \text { NPCC } & \text { New Providence Community Centre } \\ \text { PAHO } & \text { Pan American Health Organization } \\ \text { SIDS } & \text { Small Island Developing States } \\ \text { SLOSH } & \text { Sea Lake and Overland Surges from Hurricanes } \\ \text { SNA } & \text { System of National Accounts } \\ \text { SPC } & \text { Segregated Portfolio Company } \\ \text { WHO } & \text { World Health Organization } \\ \text { WSC } & \text { Water and Sewerage Company } \\ \text { WTTC } & \text { World Travel and Tourism Council } \\ & \end{array}$





\section{Executive Summary}

Hurricane Irma was the largest hurricane observed in the Atlantic open ocean, maintaining a Category 5 for three days, and made landfall over Turks and Caicos, and later Barbuda, before reaching the southern islands of The Bahamas. Warning systems were activated in a timely manner and allowed people to evacuate or seek shelter in advance. It is estimated that 3515 people were successfully evacuated, and while most evacuees had family or friends to take them in, it is estimated that 133 public shelters were used from 6 September, and most people were able to return by 10 September. However, a few shelters remained open for extended periods of time.

Hurricane Irma caused moderate damage throughout the country, particularly affecting the productive private subsectors of tourism and fisheries, as well as causing important environmental damage. Most of the damage sustained resulted from excess rainfall, storm surge and flooding. It is estimated that the total damage is $\$ 32.3$ million, of which 40.5 per cent is public and 59.5 per cent private. The most affected subsectors were housing, roads and airports, and telecommunications which accounted for 45.2 per cent, 32 per cent and 6.6 per cent of the total damage, respectively. In regard to the sectoral classification of damage, the social sector accounts for 52.2 per cent, followed by infrastructure (42.6 per cent), and productive (5.2 per cent).

Losses were estimated to be $\$ 86.9$ million and were sustained primarily in the private sector, which accounted for 96.6 per cent of the total. The productive sector accounts for most of the losses, with 93 per cent. The infrastructure sector accounts for 4.2 per cent of the losses, followed by social (2.5 per cent).

In regard to additional costs, the attention of the emergency has been undertaken mainly by the public sector. Expenditures in demolition, removal of rubble and debris, and rehabilitation of water, telecommunications and power systems add up to \$ 9 million. Total additional costs are estimated to be \$11.6 million. Approximately 62.6 per cent of the efforts have been assumed by the public sector. Based on the information received and on observations from sector specialists, the last part of the report proposes a series of recommendations, which are intended to provide a framework for a resilient reconstruction process that considers the most relevant findings in each sector. A comprehensive and resilient reconstruction process requires a combination of structural and non-structural measures to reduce social, economic and environmental vulnerabilities, rather than isolated measures.

The assessment team visited The Bahamas and its most affected areas the week of 25 September, and obtained interviews and meetings with sector specialists. The information presented in this report was obtained from various institutions of the Government of The Bahamas, private sector, non-governmental organizations, academia, local inhabitants and observations during the field visits. Information and data gaps were also identified and presented the main limitation to the findings presented in this report. All estimates in the report are represented in US dollars. This is the third report the Assessment Team prepares in the same number of years. This reports benefits from the learning experience in the previous, and the intense collaboration the authorities of The Bahamas had with the IDB and ECLAC. This assessment is a crucial input for the preparation of the recovery plan. 



\section{Introduction}

Hurricane Irma was the ninth named hurricane of the 2017 Atlantic Hurricane Season. A Cape Verde-type hurricane, Irma originated as a wave of dust and heat coming off the Sahara Desert met the warm waters off the coast of West Africa, and spent the next few days gaining size and momentum. On September 5, with its center about 270 miles east of Antigua, Irma became a Category 5 hurricane with maximum sustained winds of $175 \mathrm{mph}(280 \mathrm{~km} / \mathrm{h}$ ) and even higher gusts.

On 8 September around 01:00 UTC-5, the center of Hurricane Irma had crossed the Bahamian island Little Inagua. Around that point, the storm began to go through an eyewall replacement cycle, which caused it to weaken to a Category 4, but it regained Category 5 status 18 hours later prior to making landfall in Cuba.

Being an Archipelago in the Caribbean, a great portion of The Bahamas infrastructure is in proximity to the coast, making it particularly vulnerable to tropical storms. Irma directly and primarily affected the southern islands of Inagua, Acklins, Ragged Island and Southern Andros, and affected Bimini and Grand Bahama to the north, while it also caused moderate effects across the country. Whenever possible, the assessment team included information collected from other affected islands.

The effects of hurricane Irma on the population of The Bahamas were moderate. According to the reports prepared by the government entities responsible for the emergency, no fatalities or serious injuries were reported. The greatest damage which directly affected the population of the islands under analysis occurred in the housing sector.

The Government of The Bahamas requested from the Economic Commission for Latin America and the Caribbean (ECLAC) and the Inter-American Development Bank (IDB) an assessment of the damage, losses, and additional costs caused by hurricane Irma. ECLAC also invited PAHO to be part of the assessment team.

The assessment of the effects and impacts caused by Hurricane Irma follows the Disaster Assessment Methodology developed by the Economic Commission for Latin America and the Caribbean (ECLAC). As detailed in ECLAC's 2014 Handbook for Disaster Assessment, the methodology allows data collection and analysis on a sectoral basis; therefore, the same criteria are applied to every sector under study. In this regard, the following concepts are used in the assessment:

i. Effects: damage, loss and additional cost.

ii. Impacts: consequences of the effects on macroeconomic variables, such as GDP, public finance or balance of payments.

iii. Damage: the effect the disaster has on the assets of each sector, expressed in monetary terms. These occur during the event giving rise to the disaster. Depending on the sector, assets may include buildings, machinery, equipment, means of transportation, furnishings, roads, ports, and stocks of final and semi-finished goods, among others.

iv. Loss: goods that go unproduced and services that go unprovided from the time the disaster occurs until full recovery and reconstruction are achieved. 
v. Additional costs: outlays required to produce goods and provide services as a result of the disaster. These represent a response by both the public and the private sectors, and may take the form of additional spending or a reallocation of spending.

To quantify economic damages, losses, and additional costs associated with Hurricane Irma the members of the ECLAC-IDB-PAHO team visited The Bahamas from September 24 to September 30, 2017, and held discussions with the national authorities and key private-sector stakeholders. There they visited several of the Out Islands (Inagua, Acklins, Ragged Island, and Bimini), in addition to New Providence and Grand Bahama. After gathering all relevant data, the team was able to estimate the damage, losses and additional costs of the three main sectors: Social, infrastructure, and productive. All estimates are given in US dollars. However, as detailed in each pertinent sector, the main limitation of the assessment was access to information that either was unavailable during the assessment or is not yet collected or produced in the country. This limitation was overcome by creating reasonable assumptions where data was unavailable. Both official information and assumptions were used to estimate the effects of the hurricane and are presented in each section.

Table 1- Sectors and Subsectors of ECLAC-IDB's Assessment

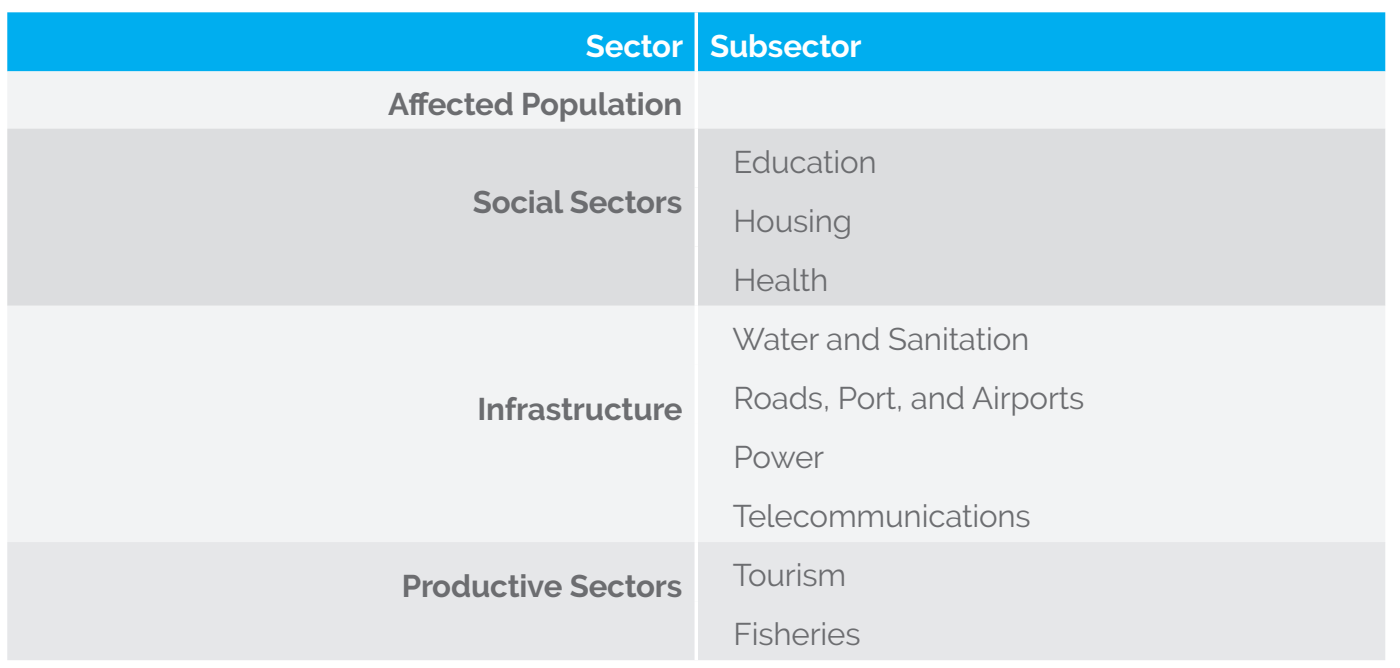

The social sector is divided into education, housing, and health subsectors. Infrastructure consists of transportation (roads, ports, and airports), power, telecommunications, and water and sanitation. The productive sector is split between the tourism and fisheries industries. The assessment also contains a chapter on the affected population of The Bahamas. In addition to the estimation of the damage, losses and additional costs, included is a macroeconomic analysis. The assessment concludes with the recommendations to help guide a resilient reconstruction process using the five pillars of disaster risk reduction. It is expected that the assessment's recommendations would contribute to the reduction of vulnerabilities and risks in every sector of the population associated with living in a small island developing state.

The estimated Damage is \$32.3 million, the Losses \$86.9 million and Additional costs $\$ 11.6$ million $^{1}$. The estimate of the effects for each sector and subsector is presented in Table $2^{2}$.

1. These additional costs do not include the evacuation cost 
Damage in the social sector was $\$ 16.8$ million. Eighty-seven per cent of the damage was to housing, 9 per cent was to education while \$0.7 million was to health. Infrastructure experienced damage amounting to \$13.7 million, of those the transportation subsector represents 75.1 per cent, \$10.3 million; and the majority of the damage was to public infrastructure. Telecommunications experienced damage of \$2.1 million, where power accounted for \$ 0.8 million and water and sanitation for $\$ 0.5$ million. Productive sectors suffered relatively small damage of \$1.7 million, most of them in fisheries (\$1.1 million) and the rest to tourism. Approximately 39.3 per cent of the damage was to public property and the remaining 60. 7 per cent was to private property.

Losses for the Social sector were estimated to be \$2.4 million, of those \$1.5 million were in education, \$ 0.5 million in health and \$ 0.4 million in housing. The losses in the infrastructure sector were estimated at \$3.7 million. Most of the losses were in the transportation sector (\$2.2 million), followed by water and sanitation \$ 0.9 million. The losses in power were \$ 0.4 million and \$ 0.1 million in telecommunication. Much of the total, and also the greatest effects were the losses in tourism. This sector suffered a loss of $\$ 68$ million, and account for 93.5 per cent of total losses. The losses in fisheries were \$13 million. The public losses were small 2.9 per cent compared to the 97.1 per cent of private ones.

Additional Costs were incurred mainly in the infrastructure sectors, mainly transportation ( $\$ 4.5$ million) and water and sanitation (\$3.3 million). The costs of the social sector were $\$ 2.4$ million, almost exclusively taken on by housing. Power and telecommunication sectors together suffered costs of \$1.1 million. Additional costs in the productive sector is estimated to be $\$ 0.1$ million. The costs for the public sector were \$7 million and for the private sector \$4.3 million.

Table 2- Summary of Effects of Hurricane Irma (Public and Private)

\begin{tabular}{|c|c|c|c|c|c|c|}
\hline Sector & Dan & age & & ses & Addition & Costs \\
\hline & Public & Private & Public & Private & Public & Private \\
\hline $\begin{array}{l}\text { Social } \\
\text { Sectors }\end{array}$ & $4,965,117$ & $11,882,843$ & $2,049,941$ & 341,760 & 641,559 & $1,799,740$ \\
\hline Education & $1,543,866$ & & $1,514,686$ & & 20,900 & \\
\hline Housing & $2,711,251$ & $11,882,843$ & 85,440 & 341,760 & 449,935 & $1,799,740$ \\
\hline Health & 710,000 & & 449,815 & & 170,724 & \\
\hline Infrastructure & $8,130,664$ & $5,643,474$ & 926,926 & $2,760,247$ & $6,620,460$ & $2,394,360$ \\
\hline $\begin{array}{l}\text { Water and } \\
\text { Sanitation }\end{array}$ & 475,200 & & 926,926 & & $3,342,230$ & \\
\hline $\begin{array}{l}\text { Roads, Port, } \\
\text { and Airports }\end{array}$ & $7,655,464$ & $2,687,775$ & & $2,213,269$ & $3,278,230$ & $1,254,444$ \\
\hline Power & & 821,966 & & 428,895 & & 689,696 \\
\hline $\begin{array}{l}\text { Telecommuni- } \\
\text { cations }\end{array}$ & & $2,133,733$ & & 118,083 & & 450,220 \\
\hline $\begin{array}{l}\text { Productive } \\
\text { Sectors }\end{array}$ & 0 & $1,675.711$ & 0 & $80,864,736$ & 0 & 137,223 \\
\hline Tourism & & 594,131 & & 67.927 .912 & & 137,223 \\
\hline Fisheries & & $1,081,580$ & & $12,936,824$ & & \\
\hline Total & $\$ 13,095,781$ & $\$ 19,202,028$ & $\$ 2,976,867$ & $\$ 83,966,743$ & $\$ 7,262,019$ & $\$ 4,331,323$ \\
\hline
\end{tabular}

Source: Assessment Team, 2017 
Table 3- Sectorial Effects of Hurricane Irma

\begin{tabular}{|l|r|r|r|}
\hline Sector & Damage & Losses & \multicolumn{1}{|c|}{ Additional Costs } \\
\hline Social & $16,847,960$ & $2,391,701$ & $2,441,299$ \\
\hline Infrastructure & $13,774,138$ & $3,687,172$ & $9,014,820$ \\
\hline Productive & $1,675,711$ & $80,864,736$ & 137,223 \\
\hline Total & $\$ 32,297,809$ & $\$ 86,943,610$ & $\$ 11,593,342$ \\
\hline
\end{tabular}

Source: Assessment Team, 2017

Before Hurricane Irma, growth of 1.4 per cent was forecast for 2017. After the disaster, The Bahamas economy would experience a growth of 1.0 per cent which implies that losses and additional costs affected the growth of economic activity by 0.4 per cent of the country for the year. This lower economic activity resulted in the loss of earnings of \$25.4 million and wages and salaries of \$18.7 million.

\section{Affected population}

The effects of Hurricane Irma in The Bahamas were mainly felt on five islands: Acklins, Bimini, Grand Bahamas, Inagua and Ragged Island. Approximately 892 people were evacuated from three of the five islands included in this analysis: 365 from Bimini; 487 from Inagua and 40 from Ragged Island; there were no evacuees from Acklins and Grand Bahama. Additionally, a total of 535 people went to activated shelters in the affected islands. That is, a total of 1,427 people had to leave their homes temporarily because of the hurricane in the islands under study.

At a national level, 3,515 persons were housed in approximately 133 shelters activated during the emergency. Most of these were closed on September 9 before the all clear was given for the entire Bahamas on September 10. However, the New Providence Community Centre and Kendal Isaacs Gymnasium, where most evacuees stayed, remained open until September 16 and 25 respectively.

\section{Housing and Public Building Sector}

According to the received data and field assessment, damage to housing and public buildings subsector is estimated to be \$14.5 million. Losses were calculated at \$0.4 million considering the 135 rental homes affected. Additional costs refer to cleaning of the debris, rental equipment, hand labor, staff services, appliances, and furniture. These tasks accounted for \$2.2 million.

The main problem the housing and public buildings sector encountered in this report was the wind speed recorded during Hurricane Irma (over $185 \mathrm{MPH}$ ) was greater than the wind speed protection requirement for the design of homes, having a high effect on the components such as roofs, windows, doors and shutters. 


\section{Education}

For the islands hit hardest by the hurricane, including Acklins, Bimini, Grand Bahama, Inagua and Ragged Island, a total of 30 schools and 4,636 students were affected. Hurricane Irma also had, to a lesser extent, damaging effects on the islands of Andros, Crooked Island, Exuma, Long Island and Mayaguana, and on these islands six schools received damage and 1,152 students were affected. The worst affected was the Ragged Island's all-age school, which was destroyed by wind. Ragged Island's teachers and students were relocated to schools on other islands.

All schools in The Bahamas were closed on 6 September 2017, and the majority were reopened on 12 September 2017. In a few instances schools remained closed to allow for repairs and the removal of debris.

Damage to school property was estimated at \$1.5 million. The estimated value of instruction time that was lost was also \$1.5 million. Additional costs were estimated at $\$ 20,900$. The largest portion of total estimated cost came from Grand Bahama, which represented 23 per cent of the total across all affected islands. The estimated costs from Andros were also high at 18 per cent of total costs to the sector, in large part due to the loss of teaching time.

\section{Health}

The health sector suffered minor effects from Hurricane Irma. Ragged Island, the most severely affected territory, sustained moderate damage to its local clinic.. Minor structural damage was observed in health facilities in Inagua, Acklins, Bimini and Grand Bahama. The latter is the country's second most populated island and is host to the Rand Memorial Hospital in the city of Freeport. Minor damage was also reported at the Princess Margaret Hospital; the Bahamas' largest health care facility located in Nassau, New Providence.

The total cost of Hurricane Irma for the country's health sector was estimated at \$1.3 million; largely attributed to losses due to service disruption and additional expenses. The cost of the damage sustained by the impact of Irma was estimated at \$0.7 million. Most damage was caused by wind and, to a lesser extent, water intrusion ${ }^{3}$.

\section{Roads, Ports, and Airports}

Damage to this sector was caused primarily by surge flooding rather than wind, except for the airport terminal building on Ragged Island that was destroyed by the hurricane-force winds. During the inspection visit it was confirmed that effects of Hurricane Irma wind and surge affected roads, airports, seawalls, bridges, docks and fences in Inagua, Ragged Island, Bimini and Acklins. Grand Bahama presented minor effects on infrastructure caused by tornados which occurred days after Irma impacted The Bahamas Islands.

The estimated damage to this subsector is $\$ 10.3$ million. Additional costs related to infrastructure improvement and reconstruction, debris removal, fencing

3. The Health cost does not include future health cost associated with long-term effects on health 
and other minor jobs is $\$ 4.5$ million and the losses due to storm surge effects in Bimini is estimated to be $\$ 2.2$ million, and it is also associated with damage to private docking facilities causing a service interruption at the Resort World Marina in North Bimini.

\section{Telecommunications}

In the telecommunications sector, Hurricane Irma caused downed communications lines and utility poles, loss of commercial power to mobile installations and cable nodes, rain and salt water-related damage to electrical equipment and buildings, and the breakage of undersea cables by drifting boats. Ragged Island suffered by far the most damage, followed by Grand Bahama, Inagua, Bimini and Andros.

Damage was estimated at \$2.1 million. Losses, standing for telecommunications sales forgone as a result of service outages, were estimated at \$0.1 million. The largest losses were in Grand Bahama, where over 2600 customers experienced service loss due to damage to overhead telecommunications cables, in part due to tornadic activity. Additional costs were estimated at \$0.5 million, reflecting the labor-related costs required to perform repairs, as well as generator fuel burned in the absence of commercial power.

\section{Power}

Damage from Hurricane Irma was primarily to transmission and distribution systems, and consisted of fallen power lines and utility poles, blown transformers, compromised insulators, and salt-spray accumulated on lines and equipment. Generation systems were not significantly affected.

While there were some cases where poles and lines were taken down by tornados- notably on Grand Bahama, Bimini, and Ragged Island- in most instances faults were caused by fallen trees or other debris. Electrical arching lead to damaged power lines, transformers, and insulators, and, in at least one case. caused a brush fire.

Damage was estimated at \$0.8 million. Losses, representing the amount of electricity that was not sold as a result of power outages, was estimated at \$0.4. Additional costs, consisting of overtime for staff and transport for repair crews and equipment, was estimated at \$0.7 million.

\section{Water, sanitation, and solid waste}

The interruption of power from Hurricane Irma prevented the generation and distribution of water. Diesel emergency generators were used to replace regular power in Acklins, Bimini, Inagua and Ragged Island. Distribution lines and residential connections were affected in Ragged Island and Salina Point. With the exception of the Ragged Island and Bimini underwater line, there was no substantial damage to the Water and Sewerage Corporation (WSC) facilities on any other Family Island. 
Damage was approximately $\$ 0.5$ million due to the interruption of water distribution service into dwellings, it is estimated that losses were around \$0.9 million. Additional costs, estimated as \$3.3 million, refer to the expense of managing the debris that arrived at landfills, costs for disaster assessment and recovery teams deployed and payment to fulfill restoration work.

\section{Tourism}

Irma caused extensive damage in some of the southern islands of the Lucayan Archipelago. The effects were particularly significant in Duncan Town, Matthew Town, and Salina Point. There was also important damage on Bimini due to water surge, and on Grand Bahama due to tornados.

The total damage in the tourism sector was \$0.6 million, mainly in the Out Islands. The losses are much greater, escalating to \$68 million. The additional costs were a little more than \$0.1 million. Most of the effects were concentrated in the bigger islands, although relatively the impact is greater for the smaller communities affected.

\section{Fisheries}

Irma caused extensive damage in the southern islands of the Lucayan Archipelago. The effects were particularly significant in Duncan Town, Matthew Town, and Salina Point. For some of these communities the main activity is fishing. Even if Irma did not cause great damage, it affected the most important fishing area of The Bahamas, the Great Bahama Bank.

The fisheries sector suffered \$1 million in damage and \$12.9 million in losses. The majority of the damage and losses were concentrated in New Providence and Spanish Wells, but in relative terms, the impact of Irma was stronger in small communities like Duncan Town and Salina Point.

\section{Economic growth and livelihoods}

Before Hurricane Irma, growth of 1.4 per cent was forecasted for 2017, after the disaster, The Bahamas economy would experience a growth of one per cent, which implies that losses and additional costs affected the growth of economic activity by 0.4 per cent of the country in that year. This lower economic activity resulted in the losses of earnings, and wages and salaries, of \$25.4 million and $\$ 18.7$ million, respectively. 



\section{Description of the Event}

The United States National Hurricane Center (NHC) began monitoring the disturbance on August 28. Over the next few days, showers and thunderstorms associated with the wave became better organized and gradually merged into a low-pressure area, gaining strength as it headed west. On August 30, NHC classified the disturbance as Tropical Storm Irma.

On August 31, Irma began to rapidly intensify, with winds increasing from 70 $\mathrm{mph}(110 \mathrm{~km} / \mathrm{h}$ ) to $115 \mathrm{mph}$ (185 km/h) over a 12-hour period. A strengthening subtropical ridge over the central North Atlantic pushed the storm's heading from western to southwestern direction on September 2 and 3. The first aircraft reconnaissance mission departed from Barbados on the afternoon of September 3, encountering an eye 29 miles $(47 \mathrm{~km})$ in diameter and surface winds of $115 \mathrm{mph}(185 \mathrm{~km} / \mathrm{h})$.

On September 4, after moving into more favorable conditions for its development, Irma strengthened into a Category 4 hurricane. By September 6 near 00:00 UTC, maximum sustained winds reached $185 \mathrm{mph}(295 \mathrm{~km} / \mathrm{h})$, and they continued at that rate for the next 37 hours. This made Irma the strongest hurricane ever observed in the open Atlantic Ocean, and one of only 5 hurricanes with measured winds of $185 \mathrm{mph}(295 \mathrm{~km} / \mathrm{h})$ or higher in the entire Atlantic Basin. Irma was a Category 5 hurricane for 3 days, it is rare that a storm maintains this status for such a long period of time.

A storm system this size reaches areas far away from landfall occurrence. Hurricane-force winds of Irma extended outward up to 60 miles $(95 \mathrm{~km})$ from the center and tropical storm-force winds extended outward up to 160 miles (260 km) away.

According to the NHC by 6 September storm surge and large breaking waves 15 to 20 feet ( 4.6 to $6 \mathrm{~m}$ ) were expected in Turks and Caicos Islands. Southeastern and central Bahamas expected 15 to 20 feet ( 4.6 to $6 \mathrm{~m}$ ) and Northern coast of Cuba in the warning area 5 to 10 feet (1.5 to $3 \mathrm{~m}$ ).

Irma made landfall along the northern coast of Barbuda early in the morning on September 6. While maintaining its intensity, Irma made successive landfalls at 7:00 UTC-5 in Saint Martin, and at 12:00 UTC-5 on Ginger Island and Tortola, in the British Virgin Islands. The hurricane skirted north of Puerto Rico and Hispaniola, and passed south of the Turks and Caicos Islands.

On September 8 around 01:00 UTC-5, the center of Hurricane Irma crossed the Bahamian island Little Inagua. Around that point, the storm began to go through an eyewall replacement cycle, which caused it to weaken to a Category 4 hurricane, but it regained Category 5 status 18 hours later, prior to making landfall in Cuba. The storm weakened to Category 3 due to its interaction with the Cuban landmass, but gained strength again to grow into a Category 4 hurricane while crossing over the Straits of Florida. At 8:10 UTC-5 on September 10, Irma made landfall in Cudjoe Key, Florida with maximum sustained winds of $130 \mathrm{mph}$ (215 $\mathrm{km} / \mathrm{h}$ ). As Irma hit Florida, tropical storm-force winds extended outward up to 400 miles $(644 \mathrm{~km})$ from the center, and hurricane-force winds extended 80 
miles (129 km). Therefore, long periods of heavy rain and strong winds, storm surge, and flooding occurred well away from storm center. Irma weakened into a Category 2 storm once inland, and dropped below hurricane intensity at 07:00 UTC-5 on September 11. On September 12, Irma weakened to a tropical depression over the Georgia-Alabama border and degenerated into a post-tropical low about 24 hours later in northern Mississippi. On September 16, Irma's remnant circulation collapsed, and the majority of its moisture was subsequently absorbed into Hurricane Jose.

Irma caused catastrophic damage in Barbuda, Saint Bartholome, Saint Martin, Anguila and the Virgin Islands as a Category 5 Hurricane. The hurricane has caused at least 132 deaths.

Figure 1- Path of Hurricane Irma across the Atlantic

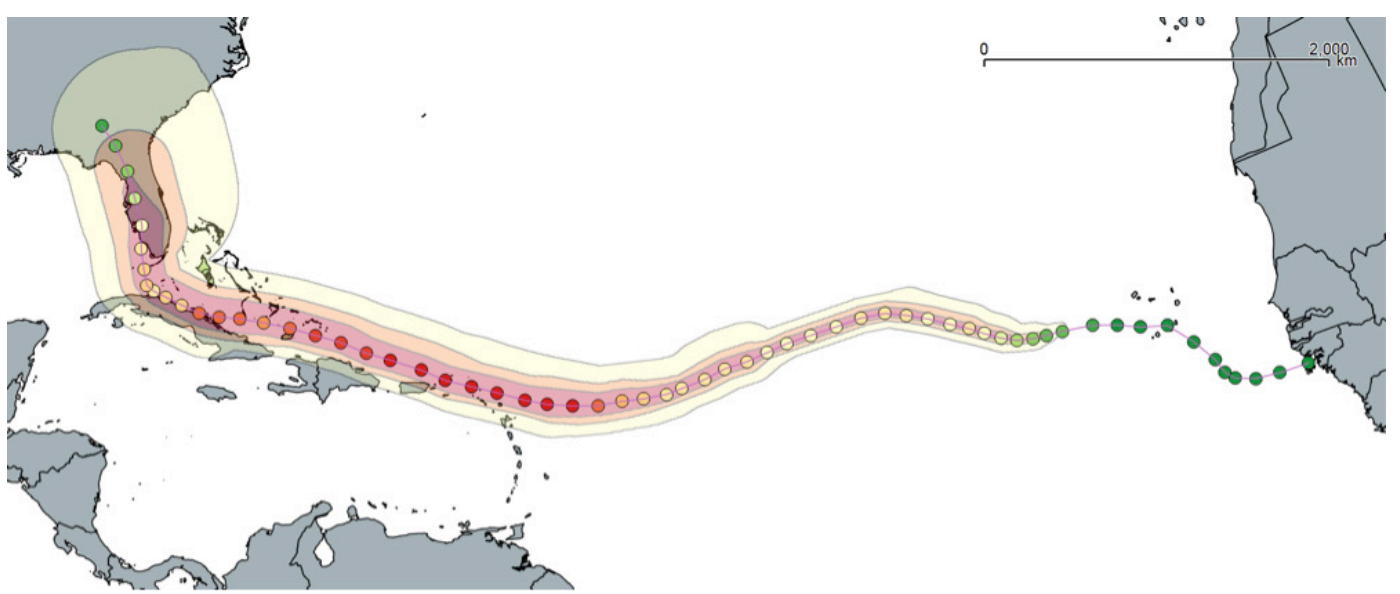

Source: ECLAC, using data provided by the United States National Oceanic and Atmospheric Administration (NOAA), 2017

Figure 2- Path of Hurricane Irma in the Northern Caribbean and Western Atlantic

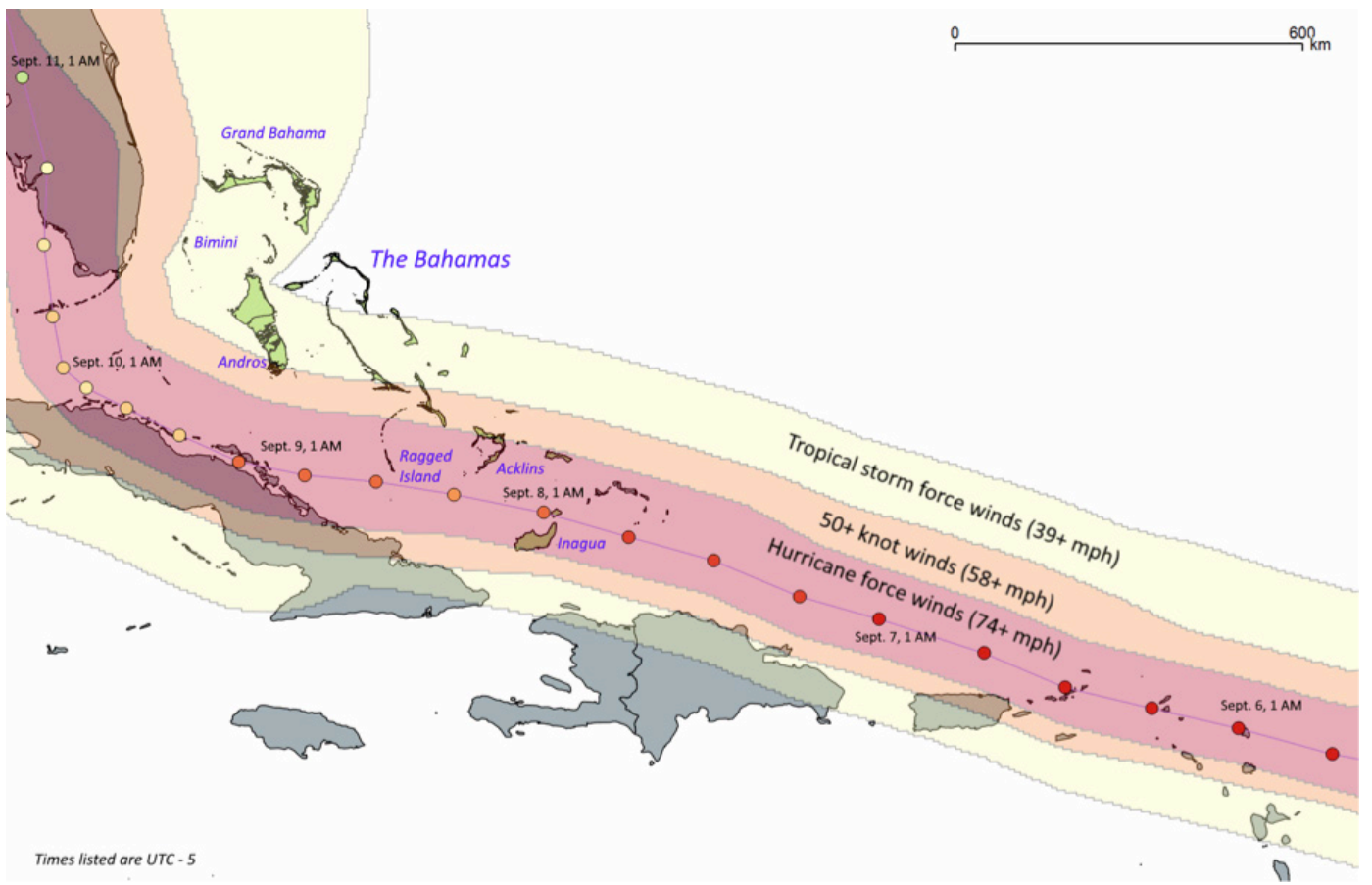

Source: ECLAC, using data provided by the United States National Oceanic and Atmospheric Administration (NOAA), 2017 


\section{Hurricane Irma in The Bahamas}

On September 6 The Bahamas Department of Meteorology published Alert \#9, detailing the track of the storm and the potential threat to The Bahamas and it said:

- $\quad$ The eye of potentially catastrophic category 5 Hurricane Irma is moving away from Barbuda and toward St. Martin.

- $\quad$ A hurricane warning is now in effect for the islands of the Southeast Bahamas and the Turks and Caicos Islands. This includes the islands of Mayaguana, Inagua, Crooked Island, Acklins, Ragged Island, Long Cay, Samana Cay the Turks and Caicos Islands.

- A hurricane warning means that hurricane conditions could affect the mentioned islands within 36 hours.

- A Hurricane Watch is now in effect for the islands of the Central Bahamas. This includes the islands of Long Island, Cat Island, Rum Cay, San Salvador and the Exumas...

- $\quad$ Residents in Inagua, Mayaguana, Crooked Island, Acklins, Ragged Island, Long Cay, Samana Cay and the Turks and Caicos Islands should rush to complete all preparation as Hurricane Irma could begin to affect these islands on Thursday afternoon. Residents in Long Island, Cat Island, Rum Cay, San Salvador and The Exumas should seriously begin preparation for the dangerous hurricane, which could possibly begin to affect them on Friday morning. Residents in Eleuthera, New Providence, Andros, The Berry Islands, Bimini, Grand Bahama and Abaco should also begin to make preparation for possible affects from Hurricane Irma and continue to listen and pay close attention to all alerts issued by The Bahamas Department of Meteorology.

- $\quad$ Extensive to severe flooding can be expected as Irma is forecast to produce rainfall amounts of 8 to 12 inches over Inagua, Mayaguana, Crooked Island, Acklins, Ragged Island, Long Cay and the Turks and Caicos Islands.

- $\quad$ The combination of a dangerous storm surge and large and destructive waves could raise water levels by as much as 15 to 20 feet above normal tide in Inagua, Mayaguana, Crooked Island, Acklins, Ragged Island, Long Cay, Samana Cay and the Turks and Caicos Islands. Residents residing on the coast in these islands are asked to immediately seek shelter further inland.

Prior to Irma reaching The Bahamas, the decision was made to execute an emergency evacuation plan from the most threatened islands to Nassau in New Providence. The emergency evacuation process included residents from Mayaguana, Inagua, Crooked Island, Acklins, Long Cay and Ragged Island. According to data provided by the Ministry of Social Services, in total 1,393 people were evacuated. On Wednesday September 6, 1,023 people were evacuated from Mayaguana, Inagua, Crooked Island, Long Cay and Ragged Island. The remaining 370 people were evacuated on Thursday 7 September from Bimini and Cat Cay. 
A government press release described the passage of Hurricane Irma over The Bahamas as follows:

- Hurricane Irma entered The Bahamas as a Category 5 storm on Thursday, September 7, with sustained winds of 175 miles per hour. The center of Irma passed over Little Inagua at about 1 a.m. Friday (September 8) and continued moving west, northwest, passing about 30 miles south of Salina Point, Acklins, at about 6 a.m. Friday as a Category 5 Hurricane.

- $\quad$ Hurricane Irma weakened slightly to a Category 4 storm with sustained winds of 150 miles per hour before its center passed over Ragged Island at about mid-day Friday (September 8).

- $\quad$ Irma continued moving westward towards and along the northern coast of Cuba before turning northward and crossing the lower Florida Cays on Sunday morning (September 10) before making landfall on the southwest coast of Florida later that day.

- Hurricane-force winds were experienced in the islands of Inagua, Mayaguana, Acklins and Crooked Island on Thursday night (September 7) and early Friday morning (September 8); in south Long Island on Friday morning (September 8) and in Ragged Island Friday morning and afternoon.

- $\quad$ Tropical storm-force winds were experienced in north Long Island, Long Cay, Exuma and its Cays, Rum Cay, San Salvador, Cat Island, Andros, New Providence, Bimini and Grand Bahama.

- $\quad$ There were reports of tornado activity embedded in thunderstorms associated with some outer bands of Irma in Bimini and Grand Bahama on Sunday (September 10, 2017).

Based on this description, assessment reports from different government institutions responsible for civil protection, emergency management entities, and the field assessment conducted by the ECLAC team between 25 to 29 September, it has been concluded that the most affected islands were Acklins, Inagua (Great Inagua) and Ragged Island in the southeastern part of The Bahamas, as well as Bimini and Grand Bahama in the north. The main effects provoked by Hurricane Irma to these five islands that are included in this study are described below.

\section{Acklins}

Hurricane Irma passed south of Acklins in the early hours of Friday, September 8. The days before Irma reach the island, 39 residents went to the shelter that was activated during the emergency. As seen in Figure 3, hurricane-force winds affected the southern part of the island. On the other hand, the northern section of the island experienced winds characterized as a tropical storm. This reversed the pattern seen in Hurricane Joaquin, where it was the north of the island that experienced higher wind speed.

Salina Point, near the southern tip of the island, was the most affected town. Significant damage was caused by storm surge which overwhelmed the sea- 
wall and washed out portions of the road leading into town. The storm surge also affected the cemetery, causing bodies to be disinterred. Many houses, the school, and small businesses were impacted by wind damage, particularly in roof structures. A NEMA trailer that had been parked in the town since Hurricane Joaquin, had been blown into a house. While there were downed power lines, there was no major damage to poles. During the field visit on 28 September, the school was closed due to damage.

Figure 3- Force wind swaths of Irma - Salina Point - Acklins

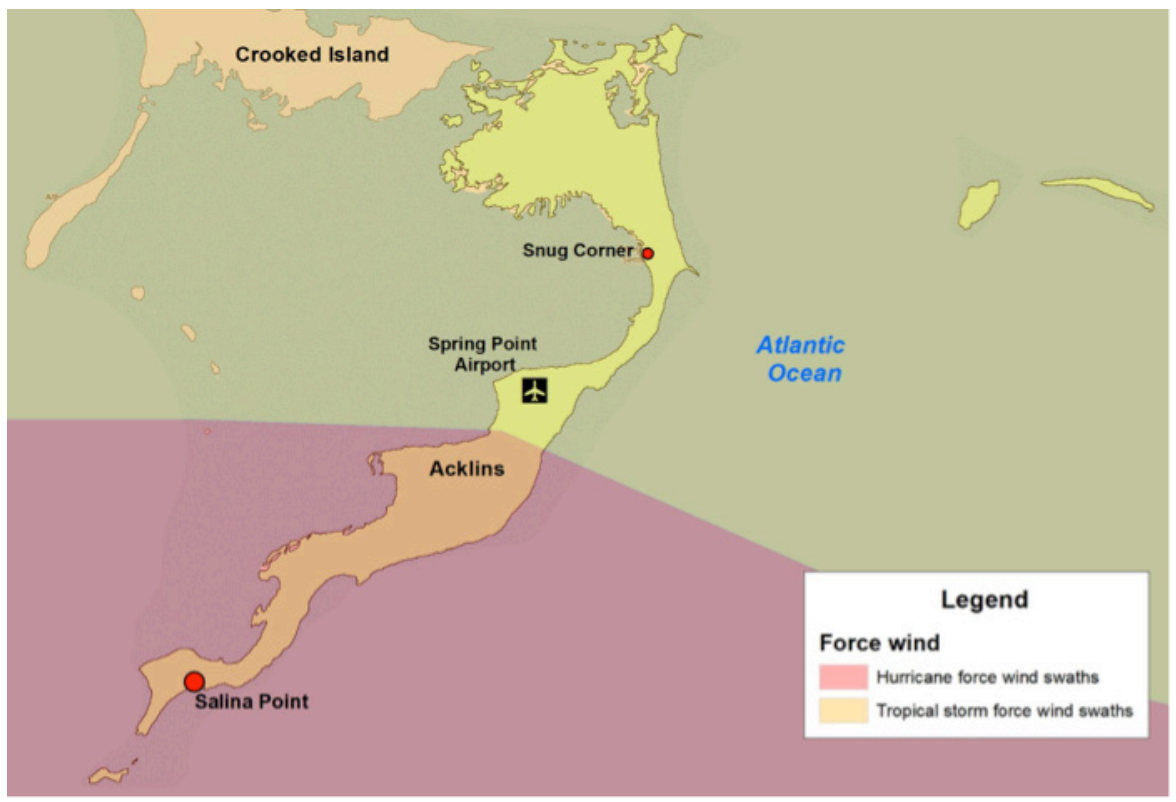

Source: ECLAC, using data provided by the United States National Oceanic and Atmospheric Administration (NOAA), 2017

\section{Bimini}

Irma affected Bimini during the daylight hours of Sunday September 8. The impact on this island was moderate, most damage was due to tornadic activity associated with tropical storm-force winds, as well as storm surge and wave action. According to the inhabitants interviewed during the field mission, strong winds lasted about twelve hours. As in the other islands, before the storm 365 people were evacuated to Nassau and 97 went to the available shelters.

During the field visit, minor damage to the roof of houses was observed, though, in a few instances, entire roofs were lost. Seawalls and docks on the east coast of the island were damaged and destroyed by a storm surge of about six feet. At the Bimini Bay Harbor and Marina, a recreational boat sank, and a number of floating docks were destroyed, causing the release of a large quantity of polystyrene pellets into the marine environment. There was also a significant impact to the tourism industry on the island, both as a result of damage and because many hotel reservations were canceled in the weeks surrounding the hurricane. 
Figure 4- Force Wind Swaths of Irma -Salina Point - Bimini

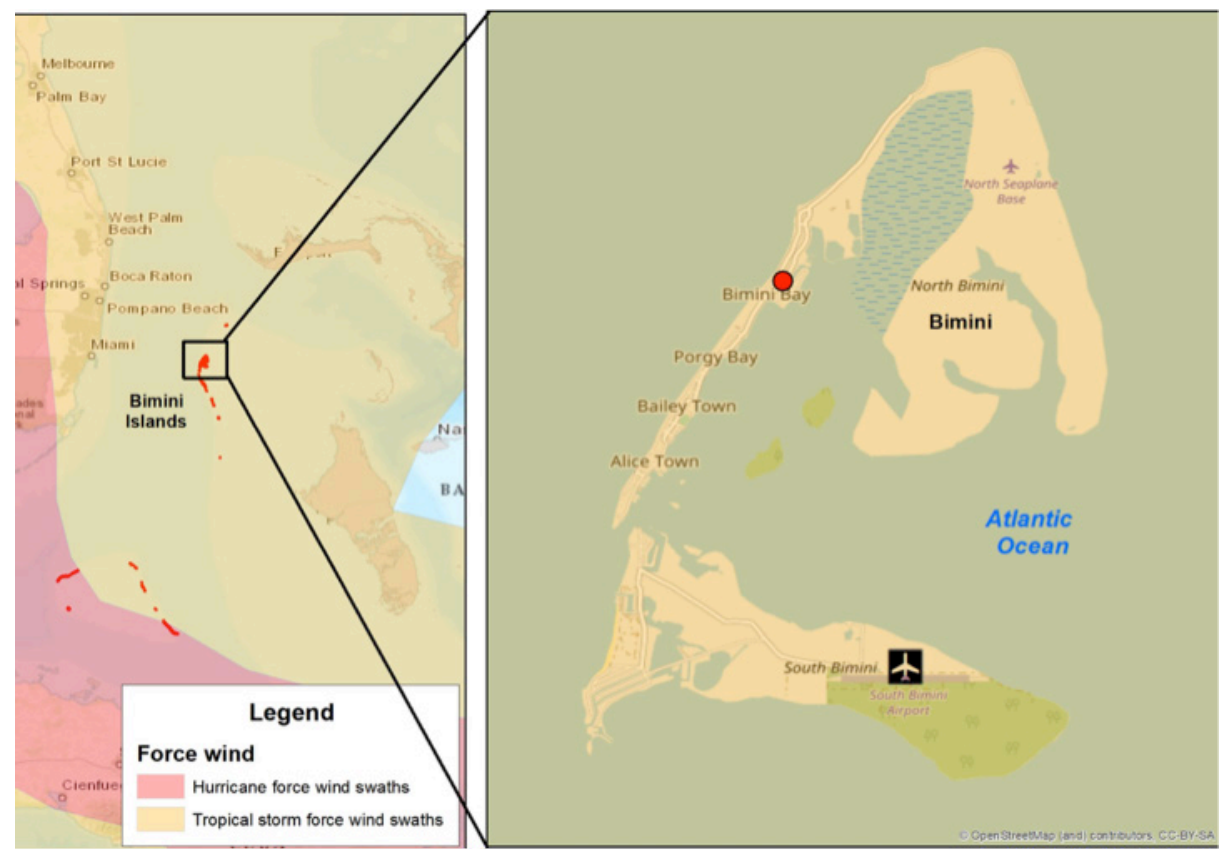

Source: ECLAC, using data provided by the United States National Oceanic and Atmospheric Administration (NOAA), 2017

\section{Grand Bahama}

Grand Bahama was affected by tropical storm-force winds on 10 September. Based on information provided by representatives of the Ministry of Social Services, 11 shelters were activated to house 398 people who evacuated from vulnerable places.

Damage to the island was mainly caused by tornados that touched down in Freeport City. According to interviews with Ministry of Works personnel, seven tornados occurred and affected the island. Based on government information published in the press releases web page, approximately 100 residents were affected by tornados

These events mainly affected the roofs of some houses, as well as power and telecommunications distribution lines. Overall, the level of damage was low to moderate, though in one case an entire roof was lifted from its house. Assessment teams from NEMA informed the assessment team that 12 homes and one business were struck. In addition, the Lodge Hall and East Sunrise Highway were also impacted with significant roof destruction. Other affected areas included Alexis Drive in Imperial Park where 13 homes were damaged. An eight-unit building on East Beach Drive also had roof damage. 
Figure 5- Force wind swaths of Irma - Grand Bahama - Free Port

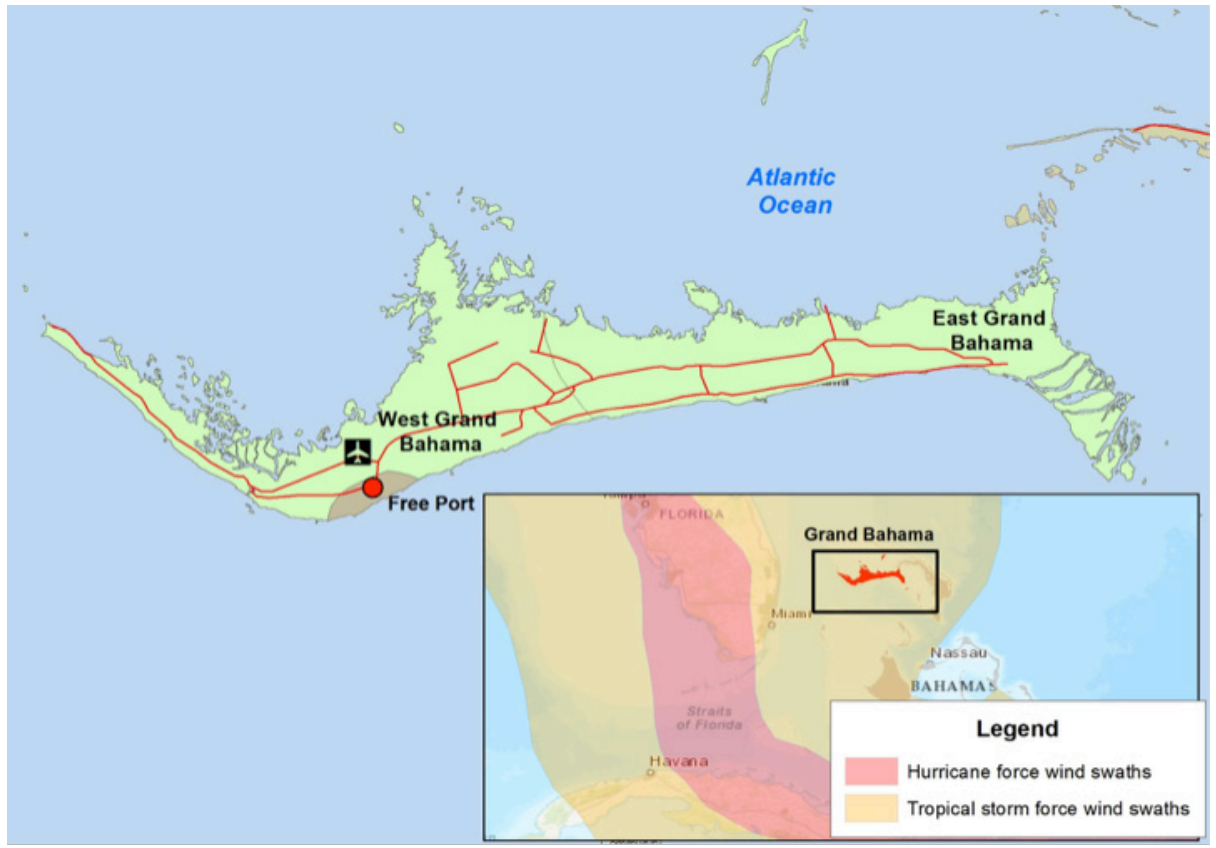

Source: ECLAC, using data provided by the United States National Oceanic and Atmospheric Administration (NOAA), 2017

\section{Inagua}

Inagua was the first island in The Bahamas that was affected by Hurricane Irma, which arrived as a Category 5 storm in the early hours of Friday, 8 September. Irma's center passed across Little Inagua Island and continued to move west near Great Inagua Island with sustained winds of 175 miles per hour (Figure 6). Winds of 155-165 mph were experienced in the island's main settlement of Matthew Town, and storm surges were measured at 10 feet.

Prior to Irma's arrival, on 6 and 7 September, over 500 of the island's approximately 913 residents were evacuated to Nassau. The evacuees returned between 12 and 14 September.

Most damage to homes occurred in the main settlement of Mathew Town, generally observed as moderate roof damage, including the loss of shingles. The storm left significant amounts of debris on roads and in the port area, which had to be cleared. The Morton Salt facility, which is the island's primary employer, lost the roof of a large maintenance building, although this did not have a significant impact on salt production. 
Figure 6 - Force wind swaths of Irma - Great Inagua (Inagua)

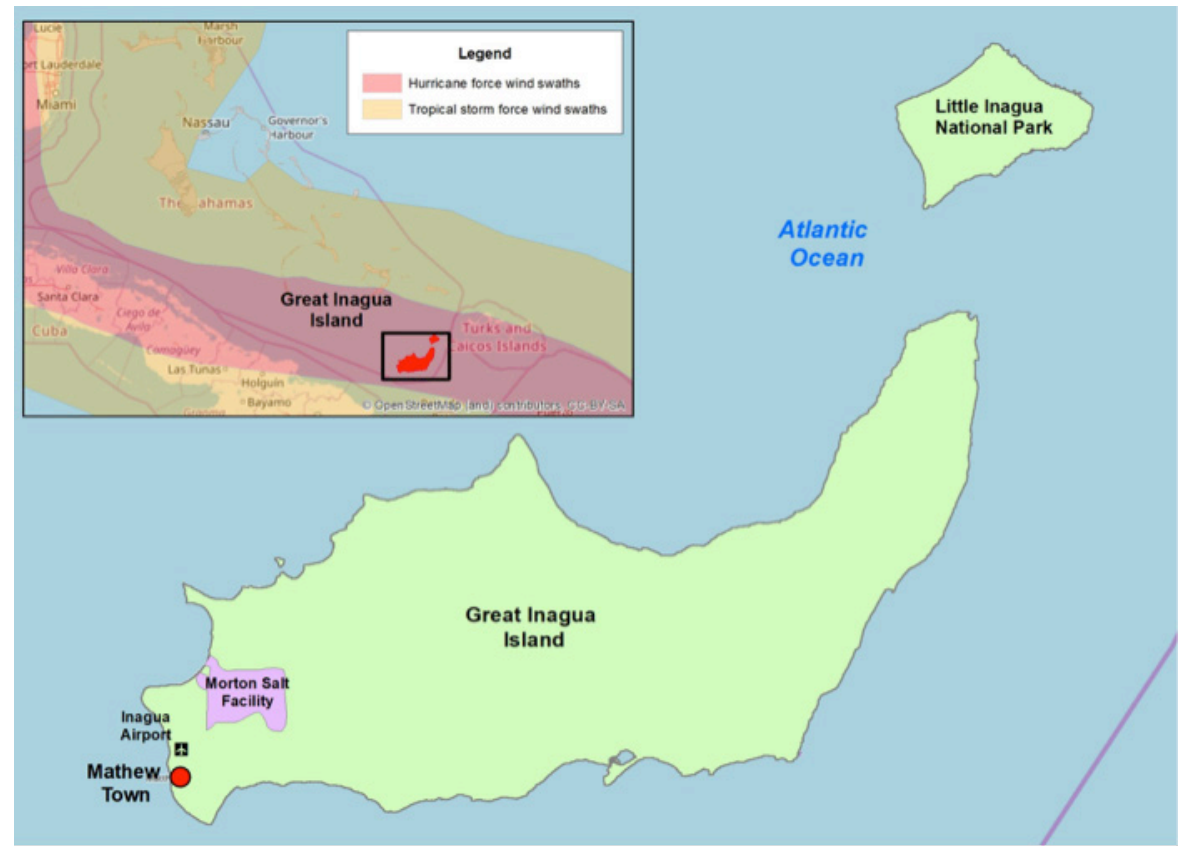

Source: ECLAC, using data provided by the United States National Oceanic and Atmospheric Administration (NOAA), 2017

\section{Ragged Island}

Ragged Island was the community in The Bahamas most heavily affected by the storm. Irma was a Category 4 when it impacted the island, with winds of 150 miles per hour. The center of the hurricane passed about 15 miles to the south of Ragged Island on the afternoon of 8 September (Figure 7). All but 18 of the islands 72 residents had evacuated the island.

The damage was severe in Duncan Town, with homes, official buildings, the school, water system, telecommunications infrastructure, and the power grid being destroyed. The island's water system telecommunications infrastructure and power grid suffered heavy damage, though the island's diesel generator remained functional. The airport terminal was destroyed, and the runway was cracked, though the roads and the port facilities were not severely damaged. According to Bahamas Government estimates, nearly 90 per cent of buildings were destroyed or severely damaged. The primary cause of damage to the island was high wind, as most of the settled area is elevated above areas that were affected by storm surge. However, the storm surge cut a channel that allowed ocean water to flood into the salt pans that provide an economic resource to the community. 
Figure 7- Force wind swaths of Irma - Ragged Island

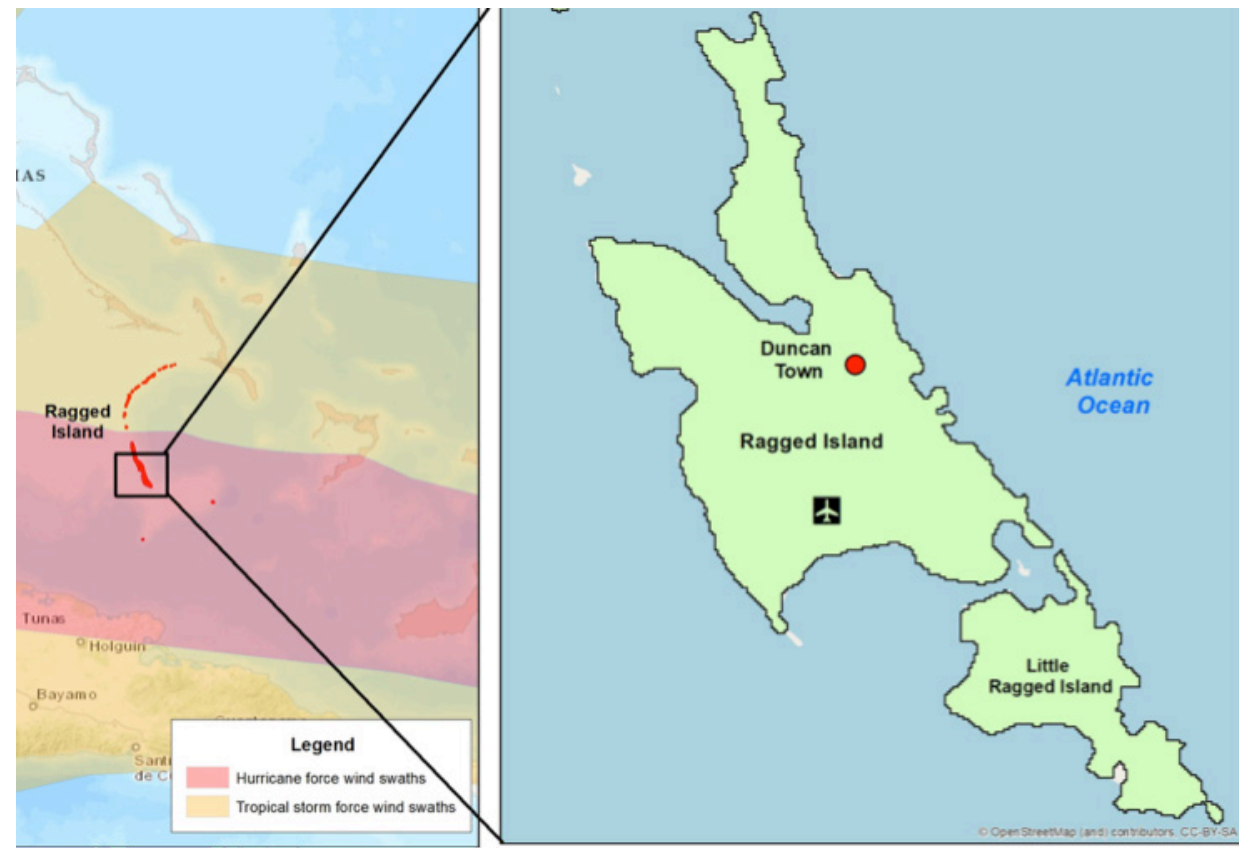

Source: ECLAC, using data provided by the United States National Oceanic and Atmospheric Administration (NOAA), 2017

\section{Hurricane Maria}

Following Hurricane Irma's passage through The Bahamas, on 21 September NEMA partially activated the National Emergency Operation Center (NEOC) to follow up on Hurricane Maria which threatened the country.

On 21 September, the islands in the southeast Bahamas, Mayaguana, Inagua, Crooked Island, Acklins, Long Cay, Samana Cay and the Turks and Caicos were under a hurricane warning and expected to feel hurricane conditions within 36 hours. Also, a tropical storm watch was issued for the Central Bahamas, including Cat Island, Exuma, Long Island, Rum Cay and San Salvador that last 48 hours. 22 September shelters were activated to accommodate residents living near the coasts.

Prior to reaching The Bahamas on 22 September, the hurricane turned north-northwest and weakened to Category 3 and then to Category 2, on 24 September. Therefore, Maria did not directly hit The Bahamas.

However, due to the published warnings and threats of the effects of Maria, some recovery works related to Irma were delayed. In addition, some assessment teams from different entities had to delay their visits to the affected islands. The tourist sector was affected from the increased cancelations of hotel reservations. 


\section{Weather-related Events in The Bahamas}

The registry of hurricane activity in The Bahamas dates to 1804 . Since that time, a hurricane has passed near The Bahamas, on average, every two years, making landfall on average every four to five years. In the period 1990-2017 $7^{4}$ the country was affected by six tropical storms and 27 hurricanes (Table 4). During this time, the rate of occurrence for hurricanes and tropical storms has been significantly higher than the long-term average.

Table 4- Tropical Storms and Hurricanes in The Bahamas (1990-2017)

\begin{tabular}{|c|c|}
\hline Year & Event \\
\hline 1990 & Hurricane Klaus \\
\hline 1991 & Tropical storm Fabian \\
\hline 1992 & Hurricane Andrew \\
\hline 1995 & Hurricane Erin \\
\hline 1996 & $\begin{array}{l}\text { Hurricane Bertha } \\
\text { Hurricane Lili }\end{array}$ \\
\hline 1998 & $\begin{array}{l}\text { Hurricane Georges } \\
\text { Hurricane Inez }\end{array}$ \\
\hline \multirow{4}{*}{1999} & Hurricane Dennis \\
\hline & Hurricane Floyd \\
\hline & Tropical storm Harvey \\
\hline & Tropical storm Irene \\
\hline 2001 & Hurricane Michelle \\
\hline \multirow{2}{*}{2004} & Hurricane Frances \\
\hline & Hurricane Jeanne \\
\hline
\end{tabular}

\begin{tabular}{|c|c|}
\hline Year & Event \\
\hline \multirow{3}{*}{2005} & Hurricane Katrina \\
\hline & Hurricane Rita \\
\hline & Hurricane Wilma \\
\hline 2007 & Hurricane Noel \\
\hline \multirow{3}{*}{2008} & Hurricane Hanna \\
\hline & Hurricane Ike \\
\hline & Tropical storm Fay \\
\hline 2011 & Hurricane Irene \\
\hline 2012 & Hurricane Sandy \\
\hline 2014 & Hurricane Arthur \\
\hline \multirow{2}{*}{2015} & Hurricane Joaquin \\
\hline & Hurricane Kate \\
\hline \multirow{3}{*}{2016} & Tropical storm Bonnie \\
\hline & Hurricane Hermine \\
\hline & Hurricane Matthew \\
\hline \multirow{3}{*}{2017} & Hurricane Irma \\
\hline & Hurricane Maria \\
\hline & Hurricane Jose \\
\hline
\end{tabular}

Source: Assessment team based on information from the National Hurricane Center

The three-year period of 2015-2017 has been particularly eventful, with The Bahamas having experienced landfall of a Category 4 hurricane in each of those years. These were Hurricane Joaquin in 2015. Hurricane Matthew in 2016, and Hurricane Irma in 2017. Although 2017 also saw hurricanes José and Maria crossing the waters of the multi-island nation at some point, and their effects were relatively minor in comparison to Hurricane Irma, which in turn was far less destructive to the country's population centers than was Hurricane Matthew the previous year. In fact, the damage from Hurricane Matthew - and Hurricane Joaquin before it - was so extensive that rebuilding was not yet complete at the time of the passage of Hurricane Irma, and this increased the vulnerability of individuals and assets in the archipelago during that storm. 
The increased frequency of these high-magnitude tropical cyclones highlights the need for policymakers and international partners to have a clear understanding of the impacts and related costs of such events. In addition, the Bahamian islands' high level of exposure to phenomena related to climate change ${ }^{5}$ exacerbates the effects of these weather events, thus affecting overall economic development, the well-being of the country's population, and the cost and complexity of disaster preparedness and resilient reconstruction efforts. The unpredictability of such weather events hinders the country's ability to make the capital investments and recurring expenditures necessary to meet its goals for sustainable social and economic development, including those enumerated as part of Vision 2040, which is the National Development Plan of The Bahamas. Furthermore, the costs of these recurring storms constrain the capacity of the government to invest in the development of disaster risk management strategies and plans that will enable the country better to withstand future events. This latter point is particularly relevant when considering the dispersion of human settlements across the archipelago makes it difficult for policy makers to establish homogeneous strategies to enhance resilience and response to tropical storms and hurricanes ${ }^{6}$.

The Damage and Loss Assessment (DaLA) process was created for assessing and planning efforts in this direction, and to meet the need for diligent collection and analysis of comprehensive sectoral information on the socioeconomic impact of the storms. This information can in turn be used to coordinate efforts to develop and execute a comprehensive strategy for resilient and sustainable post-disaster reconstruction. In the following section $f$ the descriptions of Hurricanes Joaquin and Matthew are summarized. For a detail accounting of damage, losses and additional costs caused by those disasters and their impacts see ECLAC-IDB-PAHO (2015) and ECLAC-IDB-PAHO (2016).

\section{Hurricane Joaquin}

Hurricane Joaquin affected The Bahamas from 30 September to 2 October 2015. It reached category 4 for an extended period in the area of Crooked Island and southern Long Island, causing severe damage, as well as to Acklins, Rum Cay, and San Salvador ${ }^{7}$. According to the United States National Oceanic and Atmospheric Administration (NOAA), Joaquin was the strongest October hurricane known to have affected The Bahamas since 1866 and the strongest Atlantic hurricane of non-tropical origin in the satellite era. It was a large hurricane in terms of the area covered, with outward hurricane-force winds extending 50 miles $(80 \mathrm{~km})$ from the center, and tropical-storm-force winds reaching as far as 185 miles (295 km).

Joaquin's behavior, compared to other hurricanes, could be described as rather erratic and abrupt. The storm developed quickly, and initial forecasts predicted that it would take a more northerly course than it did. As a result, there was little warning to the affected islands; many people were caught by surprise and did not have time to prepare their homes and businesses for the onslaught of the storm. Approximately 5,028 inhabitants of the central and southern Bahamas were affected, mainly in Long Island, the most populated of the islands along Joaquin's path.

5. Mainly manifested in: Rise of sea level, increased water temperatures, erosion of coasts, the tendency for tropical cyclones to become stronger in magnitude, and ongoing ecological damage related to these factors. 


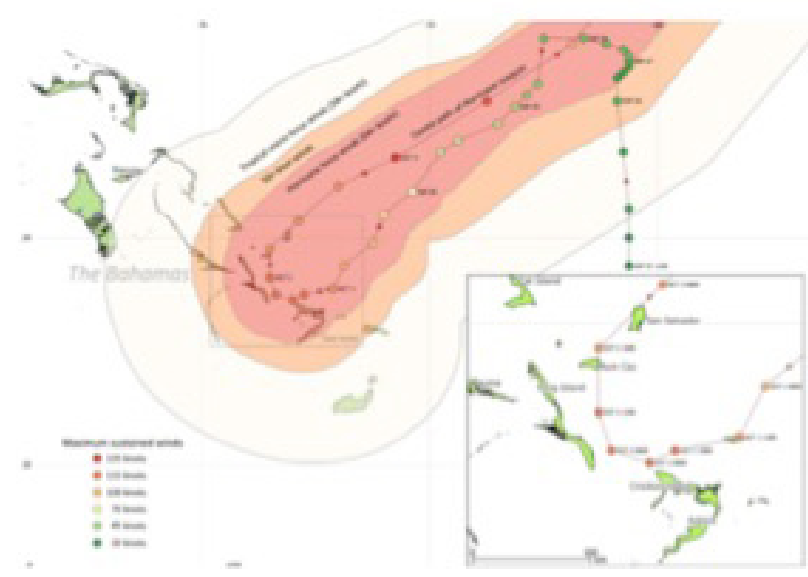

Source: National Hurricane Center, 2015

\section{Hurricane Mathew}

Hurricane Matthew moved across The Bahamas from 5 October to 7 October 2017 as a Category 3 and Category 4 hurricane ${ }^{8}$. Hurricane-force winds extended outward up to $45(72 \mathrm{~km}$ ) miles from the center and tropical storm-force winds extend outward up to $175(282 \mathrm{~km})$ miles from the center. According to NOAA, hurricane Matthew was the deadliest Atlantic hurricane since Hurricane Stan in 2005. It accounted for more than 600 direct and indirect deaths in Haiti and Cuba before arriving in The Bahamas, where only one death was attributed to the storm. Unlike Hurricane Joaquin, Hurricane Matthew's arrival in The Bahamas had been forecast with extensive lead-time, allowing for the population to prepare. Post-disaster assessments showed that approximately 8,931 people in The Bahamas were affected directly by the hurricane. This hurricane was particularly damaging to the country as it affected the major population centers of New Providence and Grand Bahamas. North Andros and the Berry Islands also strongly affected by the storm. The settlements of Lowe Sound on Andros and West End on Grand Bahama were among the hardest hit, having experienced very high storm surge. 
Figure 9- Trajectory of Hurricane Matthew, from 28 September to 9 October 2016

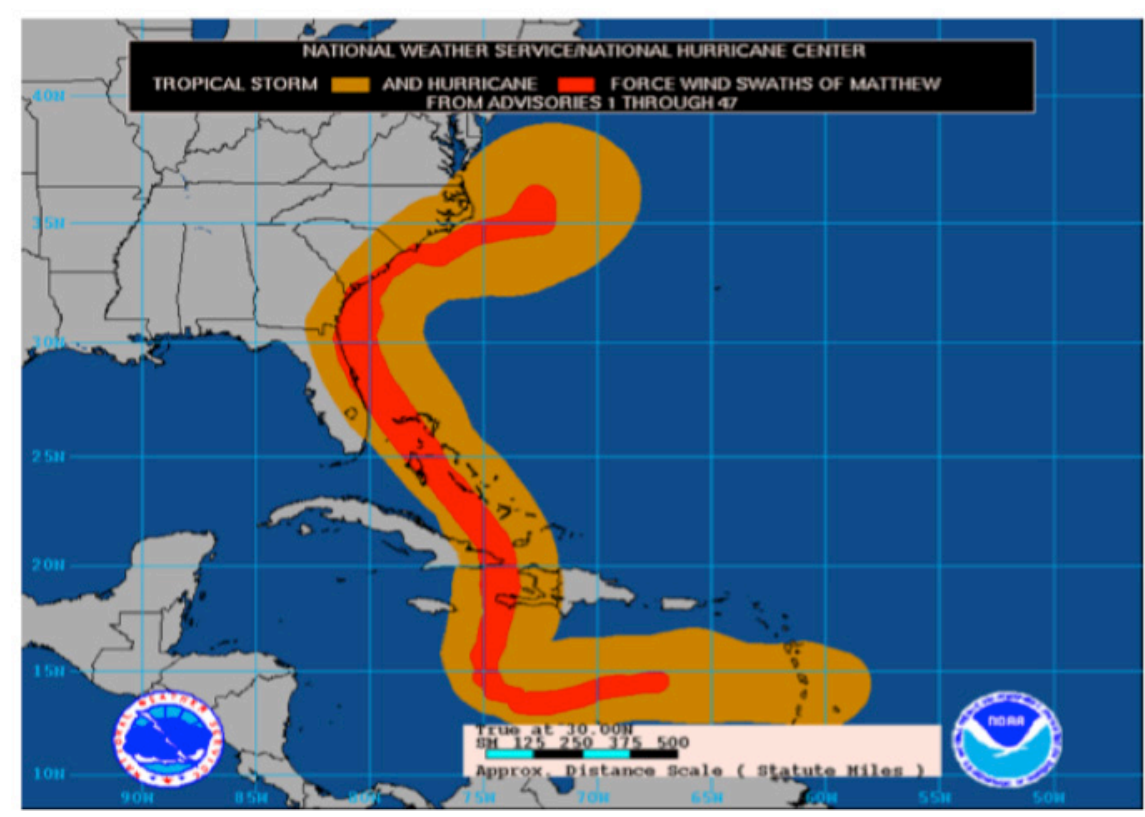

Source: National Hurricane Center, 2016 



\section{Affected Population}

\section{Introduction}

The effects of Hurricane Irma on the population of The Bahamas were moderate. According to the reports prepared by the government entities responsible for the emergency, no fatalities or serious injuries were reported. The greatest damage occurred in the housing sector, which directly affected the population of the islands under analysis.

Prior to Hurricane Irma entering The Bahamas, on 6 September the government ordered mandatory evacuation of islands that were predicted to have direct impact with Irma. About 1,479 people were evacuated to Nassau from Acklins, Crooked Island, Mayaguana, Ragged Island, Inagua and Bimini.

The effects of Hurricane Irma in The Bahamas were mainly felt on five islands: Acklins, Bimini, Grand Bahamas, Inagua and Ragged Island. Approximately 892 people were evacuated from three of the five islands included in this analysis: 365 from Bimini; 487 from Inagua and 40 from Ragged Island; there were no evacuees from Acklins and Grand Bahama. Additionally, a total of 535 people went to activated shelters in the affected islands. That is, a total of 1,427 people had to leave their homes temporarily because of the hurricane in the islands under study.

At a national level, 3,515 persons were housed in approximately 133 shelters activated during the emergency. Most of these were closed on September 9 before the all clear was given for the entire Bahamas on September 10. However, the New Providence Community Centre and Kendal Isaacs Gymnasium, where most evacuees stayed, remained open until September 16 and 25 respectively.

On the islands under study, 30 schools and 4,636 students were affected. On Andros, Crooked Island, Exuma, Long Island and Mayaguana, where the effects of Hurricane Irma were minor, six schools received damage and 1,152 students were affected.

According to the report of the housing sector a total of 387 dwellings had some type of damage affecting directly to 1,120 people. It is important to mention that 60 homes were destroyed so 171 people are displaced.

Ragged Island was the most affected, where 90 per cent of homes were reported to have damage. It is estimated that the effects of the hurricane affected the total population of the island.

Regarding telecommunications it is estimated that 5.319 customers were affected by telecommunication problems, of which 3.726 belong to the five islands included in the analysis.

The information involved in this section was obtained from the 2010 Census reports, the information collected in the field visits through interviews and the assessment reports prepared by the Ministry of Social Service and the National Emergency Management Agency (NEMA). 


\section{The Evacuation to Nassau}

Considering the forecasts and alerts issued by the different emergency entities both nationally and internationally, the impact of Hurricane Irma in The Bahamas threatened to be catastrophic, especially in the southeastern islands of the country.

Consequently, the Government of The Bahamas made the decision to execute an emergency evacuation plan from the most threatened islands to Nassau in New Providence. The emergency evacuation process included residents from Acklins, Crooked Island, Mayaguana, Ragged Island, Inagua and Bimini.

The evacuation was conducted by the National Emergency Management Agency (NEMA). The process was carried out between Wednesday 6 and Thursday 7 September. The plan was developed through 29 flights operated between The Bahamas Air Ltd., Sky Bahamas Ltd., Pineapple Air Ltd., Flamingo Air Ltd. and Western Air Ltd. Additionally, some people from Crooked Island were evacuated through the Tom Hanna mailboat. According to data provided by NEMA, in total 1,479 people were evacuated. Table 5 and Figure 8 present detailed information on the flights and number of people evacuated by each island.

Table 5- Evacuated Flights by Island, Company and Number of Persons Evacuated

\begin{tabular}{|c|c|c|c|}
\hline Island & Company & No. of flights & No. Persons \\
\hline Acklins & Bahamas Air Ltd. & 3 & 173 \\
\hline Acklins & Flamingo Air Ltd. & 1 & 40 \\
\hline Acklins & Sky Bahamas Ltd. & 3 & 80 \\
\hline Acklins & Pineapple Air Ltd. & 1 & 25 \\
\hline Crooked Island & Pineapple Air Ltd. & 2 & 35 \\
\hline Crooked Island & Sky Bahamas Ltd. & 1 & 33 \\
\hline Crooked Island & Tom Hanna Mail Boat & & 38 \\
\hline Mayaguana & Bahamas Air Ltd. & 2 & 142 \\
\hline Mayaguana & Sky Bahamas Ltd. & 1 & 21 \\
\hline Ragged Island & Sky Bahamas Ltd. & 1 & 31 \\
\hline Ragged Island & Flamingo Air Ltd. & 1 & 9 \\
\hline Inagua & Bahamas Air Ltd. & 4 & 463 \\
\hline Inagua & Flamingo Air Ltd. & 1 & 9 \\
\hline Inagua & Pineapple Air Ltd. & 1 & 15 \\
\hline Bimini & Bahamas Air Ltd. & 2 & 168 \\
\hline Bimini & Flamingo Air Ltd. & 3 & 141 \\
\hline Bimini & Pineapple Air Ltd. & 2 & 36 \\
\hline Bimini & Infants on various flights & & 20 \\
\hline TOTAL & & 29 & 1,479 \\
\hline
\end{tabular}

Source: National Emergency Management Agency, 2017 
Figure 10- Distribution of people evacuated to Nassau according to each island

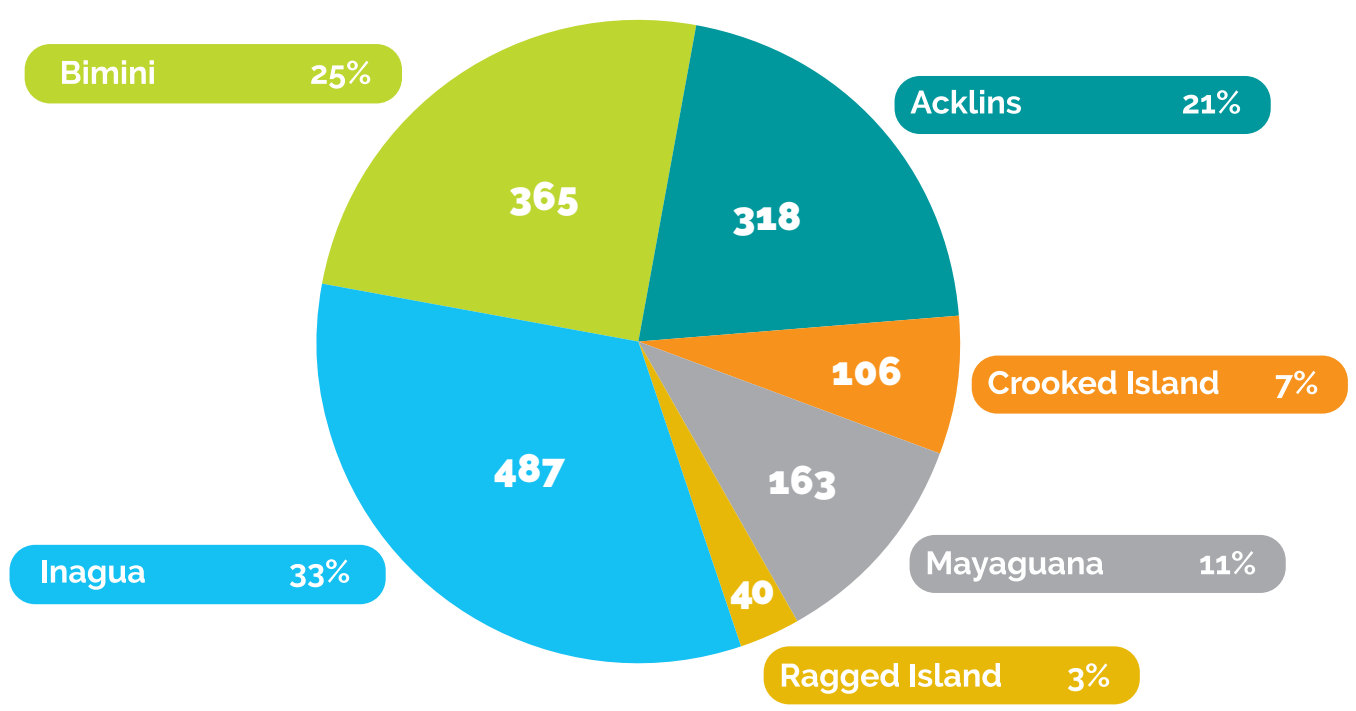

Source: National Emergency Management Agency, 2017

Most of the evacuated people to Nassau stayed with family and friends. The remaining 161 were housed in suitable shelters; 155 at the New Providence Community Centre (NPCC) and 6 persons were accommodated at the Kendall Isaac Gymnasium.

Once Hurricane Irma had passed through The Bahamas, the return of people to their home islands began on 12 September, and continued the following days. During the field visit the last 86 people returned home on 25 and 26 September.

The emergency evacuation was the largest in the history of The Bahamas. An important sign of the success of the evacuation is that no deaths or injuries were reported as a result of the hurricane. In addition, according to the interviews conducted during the field mission, on the days Irma impacted The Bahamas, controlled cuts of the basic services (electricity and water) were executed. This measure minimized the damage to the infrastructure, as reported by the personnel from Bahamas Power and Light Company.

\section{Affected Islands}

The effects of Hurricane Irma in The Bahamas were concentrated on five islands: Acklins, Bimini, Grand Bahamas, Inagua and Ragged Island. This group of islands has an approximate population of 54,906 inhabitants, representing 16 per cent of the country's total. The largest proportion of population in the affected islands was Grand Bahama, 51,568 in total (94 per cent).

It is important to note that the major damage occurred in the three islands located in the southeast of the country- Inagua, Acklins, and Ragged Island, with Ragged Island being the one that received the most damage. 
Based on the reports published by the entities responsible for emergency management and the visits made during the field mission, the populations that were most affected on each island are the following:

\begin{tabular}{ll}
- & Acklins: Salina Point \\
- & Bimini: Alice Town, Bailey Town \\
- & Grand Bahama: few areas of Freeport \\
- & Inagua: Mathew Town - Great Inagua \\
\hline & Ragged Island: Duncan Town
\end{tabular}

\section{Demographics}

Acklins, Bimini, Grand Bahama, Inagua and Ragged Island have approximately 54,906 inhabitants, who represent 16 per cent of the country's population. The population distribution among these islands, in relation to the national total, is as follows: Acklins 0.2 per cent, Bimini 0.6 per cent, Grand Bahama 14.6 per cent, Inagua 0.3 per cent and Ragged Island 0.02 per cent.

Inagua is the third largest island in area in The Bahamas with 599 square miles $(1,551 \mathrm{~km} 2)$, but has a population density of barely 2 inhabitants per square mile. On the other hand, Bimini is the smallest inhabited island in the country with an area of 11 square miles (29 km2) and with a population density of 181 people per square mile, surpassed only by New Providence with 3,079 people per square mile. Grand Bahama has the third highest population density at 97 people per square mile in an area of 530 square miles (1,373 km2). Acklins has an area of 192 square miles ( $497 \mathrm{~km} 2$ ) and a population density of 3 inhabitants per square mile, the smallest of the country. Ragged Island is one of the smallest with an area of 14 square miles (36 km2) and with 5 inhabitants per square mile.

According to the reference data of the censuses carried out in 2000 and 2010, it is possible to know the dynamics of the population for that decade. Inagua is the only island that presents a population decrease with a percentage change of -5.78 per cent. On the other hand, the one with the greatest rate of change of population between 2000 and 2010 is Acklins with 32.01 per cent. Bimini shows a percentage change of 15.78 , similar to the national average of 15.76 per cent. Grand Bahama increased its population between 2000 and 2010 by 9.31 per cent. Ragged Island shows no change in its population in that decade.

The 2010 Census established that The Bahamas has a population of 351,461, of which 48.4 per cent are men and 51.6 per cent are women. The male to female ratio is similar in Grand Bahama. However, this trend is reversed in the rest of the islands included in this analysis, where there is a higher percentage of men than women. This is most noticed in Ragged Island where 61.1 per cent are men and 38.9 per cent women.

About 26.8 per cent of the population in The Bahamas is under the age of 15 . including 8.7 per cent who are under the age of five. The productive population, aged $15-64$ is 67 per cent of The Bahamas' population, and those over 65 represent 6.2 per cent. The country's dependency ratio is 49.1 . 
Table 6- Demographics of Affected Islands

\begin{tabular}{|l|r|r|r|r|r|}
\hline \multicolumn{1}{|c|}{ Description } & Acklins & Bimini & $\begin{array}{c}\text { Grand } \\
\text { Bahama }\end{array}$ & Inagua & $\begin{array}{c}\text { Ragged } \\
\text { Island }\end{array}$ \\
\hline Population (thousands) & 565 & 1,988 & 51.368 & 913 & 72 \\
\hline Female (percentage) & 43.4 & 46.5 & 51.3 & 49.1 & 38.9 \\
\hline Male (percentage) & 56.6 & 53.5 & 48.7 & 50.9 & 61.1 \\
\hline Density (persons per sq. Mile) & 3 & 181 & 97 & 2 & 5 \\
\hline Distribution by age (percentage) & & & & & \\
\hline 0-4 years & 9.2 & 6.8 & 8.8 & 7.1 & 2.8 \\
\hline 5-14 years & 19.6 & 16.6 & 18.3 & 17.6 & 12.5 \\
\hline 15-64 years & 59.1 & 69.3 & 67 & 68.1 & 69.4 \\
\hline +65 years & 12 & 7.3 & 5.9 & 7.1 & 15.3 \\
\hline Number of households & 209 & 751 & 15.140 & 319 & 26 \\
\hline Average household size & 2.7 & 2.6 & 3.4 & 2.9 & 2.8 \\
\hline
\end{tabular}

Source: Bahamas Census, 2010

Based on 2010 Census, in The Bahamas there are 10,138 people with some form of disability. Of these, 16 per cent live on the affected islands. In these islands there are more men than women with disabilities. Grand Bahama has the highest percentage of people with disabilities among the affected islands. Ragged Island, the most affected, has the smallest population of people with disabilities, and only men. Table 7 shows the statistics for each island.

Table 7 - Disabled Population on Affected Islands

\begin{tabular}{|l|r|r|r|}
\hline \multicolumn{1}{|c|}{ Island } & Total & $\begin{array}{c}\text { Male } \\
\text { (percentage }\end{array}$ & $\begin{array}{c}\text { Female } \\
\text { (percentage) }\end{array}$ \\
\hline Acklins & 34 & 50 & 50 \\
\hline Bimini & 47 & 49 & 51 \\
\hline Grand Bahama & 1,559 & 52 & 48 \\
\hline Inagua & 18 & 56 & 44 \\
\hline Ragged Island & 2 & 100 & 0 \\
\hline TOTAL & $\mathbf{1 , 6 6 0}$ & & \\
\hline
\end{tabular}

Source: Bahamas Census, 2010 


\section{Affected Population}

Overall, the repercussions of Hurricane Irma in The Bahamas were moderate. The impact of the event had different levels of impact on the five islands included in this study. As described in the previous section, the three islands in the southeastern zone of the country were directly impacted. Fortunately, no deaths or injuries were reported. This was in part due to the voluntary evacuation that took place prior the hurricane's entry into The Bahamas.

The primary affected population used for this document was based on the total number of affected persons reported in the five islands that includes evacuees and those who lost their homes under Irma. The secondary affected population is considered the population that suffered indirect effects such as not being able to attend schools or from cutting the basic services of electricity, telecommunications and water.

Prior to the arrival of Hurricane Irma in The Bahamas, the government decided to evacuate the population from the islands which were predicted to have direct impact. In total, 1,479 people were evacuated to Nassau. According to reports made by NEMA, 892 people belonged to there of the islands included in the analysis: 365 from Bimini; 487 from Inagua and 40 from Ragged Island. As mentioned earlier, most of the people evacuated to Nassau stayed with relatives, only 161 came to two of the available shelters.

Aside from the people who voluntary evacuated to Nassau, about 535 were housed in the activated shelters on each of the most affected islands (42 per cent were women, 38 per cent men and 20 per cent infants). Consequently, 1,427 people were affected by the abandonment of their homes (Table 8).

Table 8 - Evacuated Population to Nassau and Population in Shelters

\begin{tabular}{|l|r|r|r|}
\hline \multicolumn{1}{|c|}{ Island } & $\begin{array}{c}\text { Number of people } \\
\text { evacuated to Nassau }\end{array}$ & $\begin{array}{c}\text { Population in } \\
\text { shelters }\end{array}$ & $\begin{array}{c}\text { Total affected } \\
\text { population }\end{array}$ \\
\hline Acklins & - & 39 & 39 \\
\hline Bimini & 365 & 97 & 462 \\
\hline Grand Bahama & - & 398 & 398 \\
\hline Inagua & 487 & 1 & 488 \\
\hline Ragged Island & 40 & & 40 \\
\hline Total & $\mathbf{8 9 2}$ & $\mathbf{5 3 5}$ & $\mathbf{1 3 2 7}$ \\
\hline
\end{tabular}

Source: Ministry of Social Services, September 2017

At national level, the Ministry of Social Services informed that, 133 shelters were activated: 24 in New Providence, 12 in Grand Bahama and 97 in the Family Islands. In total 3,515 people were temporarily housed beginning 6 September (Table 9). 
Table 9 - Population in Shelters for all The Bahamas

\begin{tabular}{|c|c|c|c|c|c|c|c|}
\hline Island & $\begin{array}{c}\text { Total } \\
\text { population } \\
\text { in shelters }\end{array}$ & $\begin{array}{c}\text { Total } \\
\text { adults }\end{array}$ & Men & Women & $\begin{array}{l}\text { Total } \\
\text { infant }\end{array}$ & Boys & Girls \\
\hline Abaco & 105 & 66 & 23 & 43 & 39 & 19 & 20 \\
\hline Acklins & 39 & 29 & 10 & 19 & 10 & * & * \\
\hline Andros & 657 & 397 & 174 & 223 & 260 & 216 & 134 \\
\hline Berry Islands & 31 & 22 & 13 & 9 & 9 & 4 & 5 \\
\hline Bimini & 97 & 74 & 41 & 33 & 23 & 10 & 13 \\
\hline Cat Island & 106 & 57 & 19 & 38 & 49 & 16 & 33 \\
\hline $\begin{array}{l}\text { Crooked Island/ } \\
\text { Long Cay }\end{array}$ & 36 & 31 & 20 & 11 & 5 & 4 & 1 \\
\hline Eleuthera & 452 & 310 & 156 & 154 & 142 & * & * \\
\hline $\begin{array}{l}\text { Exuma and Exuma } \\
\text { Cays }\end{array}$ & 281 & 219 & 89 & 130 & 62 & 43 & 19 \\
\hline Grand Bahama & 398 & 322 & 151 & 171 & 76 & 37 & 39 \\
\hline Harbour Island & 18 & 15 & 4 & 11 & 3 & * & * \\
\hline Inagua & 1 & 1 & 1 & - & - & - & - \\
\hline Long Island & 170 & * & * & * & * & * & * \\
\hline New Providence & 1,026 & 619 & 245 & 374 & 401 & 191 & 210 \\
\hline $\begin{array}{l}\text { San Salvador/Rum } \\
\text { Cay }\end{array}$ & 98 & 63 & 17 & 46 & 35 & 11 & 24 \\
\hline Total & 3,515 & & & & & & \\
\hline
\end{tabular}

Source: Ministry of Social Services, September 2017. * Information not available.

Shelters included churches, community centers, gymnasiums, military buildings and government administrative buildings. Most of these were able to close on 9 September before the all clear was given for the entirety of The Bahamas on 10 September. However, the New Providence Community Centre and Kendal Isaacs Gymnasium, where most evacuees stayed, remained open until 16 and 25 September, respectively.

During the visits to the assessed affected islands, it was ascertained from the Ministry of Social Service that there were budget reductions for the management of shelters. Therefore, this institution could cover only basic needs such as drinks and snacks for those housed and food parcels for all shelter managers and assessment teams. Meals were provided principally by the Salvation Army, The Bahamas Red Cross Society and private institutions.

In addition, specialized ministry staff supported the evacuees with psychological assistance and entertainment activities for children. As reported by officials of the Ministry of Social Services, there were no cases of abuse or violence in shelters. Only one case was known in Grand Bahama where there was a minor problem that involved a person with mental illness. 
According to the report of the housing and public buildings subsector a total of 387 dwellings had some type of damage affecting directly to 1,120 people. A total of 60 homes were destroyed so 171 people have been displaced.

On the islands under study, 30 schools and 4,636 students were affected. On Andros, Crooked Island, Exuma, Long Island and Mayaguana, where the effects of Hurricane Irma were minor- six schools were damaged, and 1,152 students affected. All schools in The Bahamas were closed on 6 September 2017, and the majority were reopened on 12 September 2017.

Regarding the affected population by lack of basic services, according to the officials of The Bahamas Telecommunications Company (BTC) about 5.319 customers were affected. Of these 3,726 belong to the islands under analysis in this study (Acklins: 120 Bimini: 971 Grand Bahama: 2,553 Inagua: 70 and Ragged Island: 12).

Ragged Island was the most affected, where it is estimated that 90 per cent of homes have severe damage. According to interviews conducted during the field visits, 14 houses were destroyed, 11 were unoccupied and 22 had damage. In addition, the all-age school was destroyed, and teachers and students were relocated to schools on other islands. The building was also the two teachers' residence. They were married with two children, all of whom were transferred to Exuma by the Ministry of Education. By the time the island was visited, basic services like power and water had not yet been restored. 




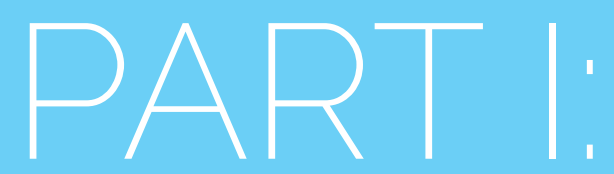

\section{ASSESSMENT OF IMPACTS AND EFFECTS}


SOCIAL SECTORS 


\section{Housing and Public Bulldings}

\section{Introduction}

Hurricane Irma severely affected the housing sector in the assessed islands, where Ragged Island and Salina Point in Acklins suffered the most severe damage. Bimini and Grand Bahama were affected, but mostly from tornadoes.

The type of building that performed best during Hurricane Irma was one with a concrete foundation, block and reinforced concrete walls, and a concrete roof. The main damage in the housing sector was due to the loss of roof covering and to windows and doors, which allowed for wind and water to affect the interior of the buildings, including electrical and mechanical equipment, creating a significative amount of damage and losses. Many settlements near coastlines suffered heavy damage from storm surge.

To carry out the damage assessment in housing and public buildings, the ECLAC group of consulting engineers visited the affected sites, interviewed the infrastructure personnel from official institutions including Ministry of Works and Urban Development and the Ministry of Environment and Housing, evaluated the standards and codes, and received and analyzed other evaluations.

According to the received data and field assessment, damage to housing and public buildings subsector is estimated to be $\$ 14.5$ million. Losses were calculated at \$0.4 million considering the 135 rental homes affected. Additional costs refer to cleaning of the debris, rental equipment, hand labor, staff services, appliances, and furniture. These tasks accounted for \$2.2 million.

The main problem the housing and public buildings sector encountered in this report was the wind speed recorded during Hurricane Irma (over $185 \mathrm{MPH}$ ) was greater than the wind speed protection requirement for the design of homes, having a high effect on the components such as roofs, windows, doors and shutters.

It should be noted that the damage calculated in this report are based on different evaluations received and the field assessment. It considers data of standard construction prices on the island and data from the 2010 census in terms of constructed surface area per household and housing type.

\section{Baseline information}

According to the 2010 Census, there were 26 occupied dwellings in Ragged Island, 319 in Great Inagua, 209 in Acklins, 751 in Bimini and 15,140 in Grand Bahama. Nationally, the average is 3.4 people per household.

During field visits to the affected islands, the ECLAC team observed that the most common roofing materials are plywood and asphalt shingles. We noticed in two of the southern islands, Salina Point in Acklins and Ragged Island, that the homes are constructed of lower standards. Construction on the other islands assessed meet very strict building codes. This coincides with the fact that in those areas around 35 per cent of households have annual incomes below \$10,000 (Table 10). 
Table 10- Dwellings by Household Income and by Island

\begin{tabular}{|c|c|c|c|c|c|c|c|c|c|c|}
\hline Island & $\begin{array}{l}0- \\
5 k\end{array}$ & $\begin{array}{c}5- \\
10 \mathrm{k}\end{array}$ & $\begin{array}{l}10- \\
15 k\end{array}$ & $\begin{array}{l}15^{-} \\
20 k\end{array}$ & $\begin{array}{l}20- \\
40 k\end{array}$ & $\begin{array}{l}40- \\
60 k\end{array}$ & $\begin{array}{l}60- \\
80 k\end{array}$ & $\begin{array}{c}80- \\
100 \mathrm{k}\end{array}$ & $\begin{array}{c}100 \mathrm{k} \\
\& \text { over }\end{array}$ & Responses \\
\hline \multirow{2}{*}{ Acklins } & 41 & 25 & 26 & 16 & 46 & 22 & 11 & 3 & 5 & 195 \\
\hline & $21 \%$ & $13 \%$ & $13 \%$ & $8 \%$ & $24 \%$ & $11 \%$ & $6 \%$ & $2 \%$ & $3 \%$ & $100 \%$ \\
\hline \multirow{2}{*}{ Bimini } & 50 & 80 & 120 & 103 & 235 & 77 & 37 & 11 & 12 & 725 \\
\hline & $7 \%$ & $11 \%$ & $17 \%$ & $14 \%$ & $32 \%$ & $11 \%$ & $5 \%$ & $2 \%$ & $2 \%$ & $100 \%$ \\
\hline \multirow{2}{*}{$\begin{array}{l}\text { Grand } \\
\text { Bahama }\end{array}$} & 816 & 1,121 & 1,344 & 1,247 & 4,531 & 2,662 & 1,326 & 589 & 789 & 14,425 \\
\hline & $6 \%$ & $8 \%$ & $9 \%$ & $9 \%$ & $31 \%$ & $18 \%$ & $9 \%$ & $4 \%$ & $5 \%$ & $100 \%$ \\
\hline \multirow{2}{*}{ Inagua } & 16 & 18 & 32 & 22 & 117 & 59 & 25 & 10 & 7 & 306 \\
\hline & $5 \%$ & $6 \%$ & $10 \%$ & $7 \%$ & $38 \%$ & $19 \%$ & $8 \%$ & $3 \%$ & $2 \%$ & $100 \%$ \\
\hline \multirow{2}{*}{ Ragged } & 2 & 6 & 1 & 2 & 5 & 2 & 5 & 0 & 0 & 23 \\
\hline & $9 \%$ & $26 \%$ & $4 \%$ & $9 \%$ & $22 \%$ & $9 \%$ & $22 \%$ & ०\% & ०\% & $100 \%$ \\
\hline
\end{tabular}

Source: Bahamas Statistics Department 2010 Census.

The Bahamas' long history of dealing with hurricanes has brought on a change in the style of construction and now most homes are built of concrete block, with poured concrete slabs and concrete foundations. This standard of construction includes approximately 75 per cent of the total houses in all the islands. Wood and timber constructions are in use as well. Most of the inspected wooden houses tend to be older and of inferior quality to those made of reinforced masonry.

\section{Damage}

The estimates in this sector are based on the assessment developed in the weeks after the event and field inspections to The Bahamas. Of the 419 dwellings affected, the ECLAC team estimates that 15 per cent were destroyed, 19 per cent have significant structural damage, 24 per cent have minor damage and 42 per cent have some form of damage. This resulted in a total estimated damage of \$14.6 million (Tables 11 \& 12).

Table 11 - Summary of Damage in the Housing and Public Buildings Sector

\begin{tabular}{|l|r|r|r|r|}
\hline \multicolumn{1}{|c|}{ Description } & $\begin{array}{r}\text { Damaged } \\
\text { Dwellings }\end{array}$ & $\begin{array}{c}\text { Cost of } \\
\text { Infrastructure }\end{array}$ & $\begin{array}{r}\text { Furniture \& } \\
\text { Equipment }\end{array}$ & \multicolumn{1}{|c|}{ Total } \\
\hline Housing & 387 & $11,610,443$ & 272,400 & $11,882,843$ \\
\hline Public Buildings & 32 & $2,507,251$ & 204,000 & $2,711,251$ \\
\hline Total & $\mathbf{4 1 9}$ & $\mathbf{\$ 1 4 , 1 1 7 , 6 9 3}$ & $\mathbf{\$ 4 7 6 , 4 0 0}$ & $\mathbf{\$ 1 4 , 5 9 4 , 0 9 3}$ \\
\hline
\end{tabular}

Source: Assessment team 
Table 12 - Summary of Damage in the Housing and Public Buildings Sector by Island

\begin{tabular}{|c|c|c|c|c|}
\hline Description & Dwellings & $\begin{array}{c}\text { Cost of } \\
\text { Infrastructure }\end{array}$ & $\begin{array}{l}\text { Furniture \& } \\
\text { Equipment }\end{array}$ & Total \\
\hline Acklins Housing & 94 & $3,662,093$ & 86,400 & $3,748,493$ \\
\hline Acklins Public Buildings & 5 & 326,251 & 36,000 & 362,251 \\
\hline Total & 99 & $3,988,344$ & 122,400 & $4,110,744$ \\
\hline Bimini Housing & 71 & $1,825,991$ & 49,200 & $1,875,191$ \\
\hline Bimini Public Buildings & 6 & 216,000 & 0 & 216,000 \\
\hline Total Bimini & 77 & $2,041,991$ & 49,200 & $2,091,191$ \\
\hline Grand Bahama Housing & 72 & $2,131,883$ & 48,000 & $2,179,883$ \\
\hline $\begin{array}{l}\text { Grand Bahama Public Buil- } \\
\text { dings }\end{array}$ & 10 & 840,000 & 60,000 & 900,000 \\
\hline Total Grand Bahama & 82 & $2,971,883$ & 108,000 & $3,079,883$ \\
\hline Inagua Housing & 124 & $1,939,783$ & 57,600 & $1,997,383$ \\
\hline Inagua Public Buildings & 5 & 292,500 & 36,000 & 328,500 \\
\hline Total Inagua & 129 & $2,232,283$ & 93,600 & $2,325,883$ \\
\hline Ragged Island Housing & 26 & $2,050,692$ & 31,200 & $2,081,892$ \\
\hline $\begin{array}{l}\text { Ragged Island Public Buil- } \\
\text { dings }\end{array}$ & 6 & 832,500 & 72,000 & 904.500 \\
\hline Total Ragged Island & 32 & $2,883,192$ & 103,200 & $2,986,392$ \\
\hline Total & 419 & $\$ 14,117,693$ & $\$ 476,400$ & $\$ 14,594,093$ \\
\hline
\end{tabular}

Source: Assessment team

\section{Acklins}

The damage in Acklins is concentrated in Salina Point. Most resulted from strong winds and storm surges. Strong winds and flying debris caused widespread damage to roofs, walls and windows. Subsequently, damaged roofs allowed water penetration, affecting ceilings, walls, furniture and electronic equipment. Additionally, storm surge affected homes in areas.

\section{Bimini}

In Bimini Hurricane Irma brought a strong swell and winds but the biggest damage in the housing area was caused by the appearance of tornadoes, causing widespread effects to roofs, walls and windows. Damaged roofs allowed the penetration of water that affected ceilings, walls, furniture and equipment.

\section{Grand Bahama}

In Grand Bahama, like Bimini, the greatest damage to housing was caused by the appearance of tornadoes, causing widespread damage to roofs, walls and windows. Later, the damaged roofs allowed the penetration of water that affected ceilings, walls, furniture and equipment. 


\section{Great Inagua}

In Great Inagua damage was along the coastline. Strong winds caused widespread damage to roofs, walls and windows. Affected roofs allowed water penetration affecting the rest of the house. Additionally, storm surge affected homes. Most settlements near bodies of water suffered severe flooding.

\section{Ragged Island}

The damage in Ragged Island was generalized and widespread. Most of the results are from strong winds and flying debris causing damage to roofs, walls and windows. Subsequently, the affected roofs allowed water penetration affecting ceilings, walls, furniture and all kinds of equipment.

In general, part of the reason for vulnerability to disaster in the southern islands is the lack of technical supervision by municipalities during construction, use of inefficient structural components and construction deficiencies, and lack of adequate maintenance of the housing, especially roof structures.

Table 13 - Levels of Damage to Housing by Island

\begin{tabular}{|l|r|r|r|r|r|}
\hline \multicolumn{1}{|c|}{ Island } & Level 1 & Level 2 & Level 3 & Level 4 & \multicolumn{1}{|c|}{ Total } \\
\hline Ragged & 0 & 2 & 14 & 16 & 32 \\
\hline Acklins & 24 & 27 & 26 & 22 & 99 \\
\hline Great Inagua & 78 & 30 & 13 & 8 & 129 \\
\hline Bimini & 36 & 20 & 15 & 6 & 77 \\
\hline Grand Bahamas & 37 & 23 & 12 & 10 & 82 \\
\hline Total & $\mathbf{1 7 5}$ & $\mathbf{1 0 2}$ & $\mathbf{8 0}$ & $\mathbf{6 2}$ & $\mathbf{4 1 9}$ \\
\hline
\end{tabular}

Source: Assessment team

The assessment team estimated damage to dwellings considering two factors:

1. Average house value, based on average house size, building class and consideration of outer walls and roofing materials.

2. Level of damage assigned to each house:

a. Level 1: No significant damage. Structure is usable and can be occupied. Repairs required are minimal.

b. Level 2: Minor damage. Structure is usable and can be occupied after urgent temporary measures are taken. Assistance will probably be required for repairs.

c. Level 3: Major damage. Structure is not usable and cannot be occupied until after repairs are made.

d. Level 4: Destroyed. Structure is not usable and cannot be repaired. Must be rebuilt.) 


\section{Losses}

Losses in the housing sector relate to the interruption of accommodation services due to severe damage or destruction of the housing stock, making it temporarily or permanently uninhabitable. Estimates focus on interruption of the service regardless of the type of residence, whether rented or owner occupied. Table 14 shows estimates losses for homes deemed uninhabitable (damage levels 3 and 4) after the hurricane.

Table 14 - Summary of Losses in the Housing and Public Buildings Sector

\begin{tabular}{|l|r|r|r|r|r|}
\hline \multicolumn{1}{|c|}{ Island } & $\begin{array}{c}\text { Uninhabitable } \\
\text { dwellings } \\
\text { (Level 3 and 4) }\end{array}$ & $\begin{array}{c}\text { Estimated } \\
\text { rent } \\
\text { per month }\end{array}$ & $\begin{array}{c}\text { Total } \\
\text { revenue per } \\
\text { month }\end{array}$ & $\begin{array}{c}\text { Construction } \\
\text { process } \\
\text { (months) }\end{array}$ & Total \\
\hline Ragged Island & 26 & 400 & 10,400 & 6 & 62,400 \\
\hline Great Inagua & 46 & 400 & 18,400 & 6 & 110,400 \\
\hline Acklins & 20 & 400 & 8,000 & 6 & 48,000 \\
\hline Bimini & 21 & 800 & 16,800 & 6 & 100,800 \\
\hline Grand Bahamas & 22 & 800 & 17,600 & 6 & 105,600 \\
\hline Total & $\mathbf{1 3 5}$ & & & $\mathbf{\$ 4 2 7 , 2 0 0}$ \\
\hline
\end{tabular}

Source: Assessment team

\section{Additional Costs}

Additional costs considered several activities such as cost of demolition of the most affected dwellings (level 4 and level 3), debris cleaning, staff services, and equipment rental. Additional costs are approximately \$2. million (Table 15). It is estimated that 80,250 cubic meters of debris needed to be removed from the affected areas. The cost to fill and transfer each truckload of debris approximately 15 cubic meters is estimated to be \$200, without considering the management of the landfill.

Table 15 - Summary of Additional Costs in the Housing and Public Buildings Sector

\begin{tabular}{|l|r|r|r|}
\hline \multicolumn{1}{|c|}{ Island } & $\begin{array}{c}\text { Demolition } \\
\text { Cost }\end{array}$ & $\begin{array}{r}\text { Debris Management } \\
\text { Cost }\end{array}$ & $\begin{array}{c}\text { Total Additional } \\
\text { Cost }\end{array}$ \\
\hline Ragged & 114,660 & 104,000 & 218,660 \\
\hline Acklins & 317,520 & 288,000 & 605,520 \\
\hline Great Inagua & 211,680 & 192,000 & 403,680 \\
\hline Bimini & 271,215 & 246,000 & 517,215 \\
\hline Grand Bahamas & 264,600 & 240,000 & 504,600 \\
\hline Total & $\mathbf{\$ 1 , 1 7 9 , 6 7 5}$ & $\mathbf{\$ 1 , 0 7 0 , 0 0 0}$ & $\mathbf{\$ 2 , 2 4 9 , 6 7 5}$ \\
\hline
\end{tabular}

Source: Assessment team 


\section{Introduction}

For the islands hit hardest by the hurricane, including Acklins, Bimini, Grand Bahama, Inagua and Ragged Island, a total of 30 schools and 4,636 students were affected. Hurricane Irma also had, to a lesser extent, damaging effects on the islands of Andros, Crooked Island, Exuma, Long Island and Mayaguana, and on these islands six schools received damage and 1,152 students were affected (Table 16). The worst affected was the Ragged Island's all-age school, which was destroyed by wind. Ragged Island's teachers and students were relocated to schools on other islands.

All schools in The Bahamas were closed on 6 September $2017^{9}$, and the majority were reopened on 12 September 2017. In a few instances schools remained closed to allow for repairs and the removal of debris.

Table 16 - Total Damage, Losses and Additional Costs

\begin{tabular}{|c|c|c|c|}
\hline Island & Damage & Losses & Additional Costs \\
\hline Acklins & 130,488 & 29,564 & 5,100 \\
\hline Andros & 509.775 & 44,273 & 2,700 \\
\hline Bimini & 39,925 & 17,253 & 600 \\
\hline Crooked Island & 19,564 & 4,946 & 600 \\
\hline Exuma & 37,100 & 833 & 300 \\
\hline Grand Bahama & 550,563 & 149,398 & 4,800 \\
\hline Inagua & 25,700 & 13,325 & 300 \\
\hline Long Island & 51,613 & 10,826 & 1,200 \\
\hline Mayaguana & 9,388 & 5,712 & 300 \\
\hline Ragged Island & 169,750 & 2,707 & 5,000 \\
\hline Undamaged Facilities ${ }^{10}$ & 0 & $1,235,849$ & 0 \\
\hline Total & $\$ 1,543,866$ & $\$ 1,514,686$ & $\$ 20,900$ \\
\hline
\end{tabular}

Source: Assessment team

This total was split roughly in half between damage to school property of $\$ 1.5$ million and the value of instruction time that was lost, estimated at \$1.5 million, plus a relatively small proportion of additional costs estimated at $\$ 20,900$. The largest portion of total estimated cost came from Grand Bahama, which represented 23 per cent of the total across all affected islands. The estimated costs from Andros were also high at 18 per cent of total costs to the sector, in large part due to the loss of teaching time.

There have been three important vulnerabilities to have significant impact to the education sector. The first is related to the maintenance of school premises. Scheduled maintenance across the country has not been consistent, leading to instances where minor key repairs are not carried out, such as the reinforce- 
ment of doors and windows. These minor neglects have, on occasion, led to more profound damage and in turn larger expenses. The second vulnerability is access to funding for repairs quickly. In instances where funding for the repair of minor damage was not provided in a timely fashion, some minor expenses grew into more substantial ones. Quick access to funding can also help provide necessary reinforcement to school property in the instance of more than one hurricane during the same year.

The third important vulnerability is that of lost teaching time. In many instances, teachers and students can catch up on lost school time through adjusting the pace of teaching during the school term; however, there were instances where a range of factors delayed the return to a normal teaching routine. Examples include: School closure due to a contaminated water supply that was not treated post-haste; many students remained at home to assist with the clean-up and repair of their homes; and the mosquito infestation of school premises and surrounding areas. These reasons are varied and must be considered on a case-bycase basis. The yearly occurrence of hurricanes and their consistent interruption of all services, coupled with the stresses that go with loss of stability, can lead to the impoverishment of schooling for Bahamian youth unless reliable countermeasures are put into place. The lost time can have a cumulative effect over the years.

It should be noted that this section assesses Hurricane Irma's impact on public education in The Bahamas. Data was provided by the Ministry of Education, and the analysis covers only government funded and operated schools, unless stated otherwise.

\section{Baseline Information}

The Education sector in The Bahamas falls under the purview of the Ministry of Education, which is responsible for over 47,000 primary and secondary level students in approximately 170 educational institutions throughout 14 districts on the major islands. The management of the government pre-primary, primary and secondary schools, including buildings, staffing and the provision of tuition and other supplies is designated to the Department of Education (DOE). Education is available freely for all residents of The Bahamas between the ages of 5-16 years; by law, students must attend school until they are 16 years of age ${ }^{11}$.

Table 17 - Categories of Schools in The Bahamas

\begin{tabular}{|l|r|}
\hline \multicolumn{1}{|c|}{ Category } & \multicolumn{1}{|c|}{ Age Group } \\
\hline Pre-school & 3 to 5 years \\
\hline Primary & 5 to $11^{+}$years \\
\hline Junior High & 11 + to 14 + years \\
Senior High & $14^{+}$to 16 + years \\
\hline All-Age & 5 to $16+$ years \\
\hline Special schools & Various ages, students with severe learning disabilities \\
\hline
\end{tabular}

Source: Assessment team 
The education system is structured in a 6-3-3 format with students from age five to 11 undergoing primary education, followed by junior high school from ages 11 to 14 and senior high school from ages 14 to 17. Secondary schools educate students through both Junior High and Senior High levels. The Bahamian education system also has a range of preschools and tertiary level institutions; however, attendance is not mandatory in those levels ${ }^{12}$. Though 70 per cent of public schools are located on the Family Islands, this accounts for only 37 per cent of the country's students and 41 per cent of the teachers.

The school calendar is organized from August to June, and students normally attend school from 08:45 to 15:00 hours. Students should receive 180 days of education per year.

Table 18 - Facilities and Students

\begin{tabular}{|c|c|c|c|c|}
\hline \multirow[t]{2}{*}{ School type } & \multirow[t]{2}{*}{ Count } & \multicolumn{3}{|c|}{ Students } \\
\hline & & Male & Female & Total \\
\hline Pre-school & 11 & 297 & 292 & 589 \\
\hline Primary & 93 & 13,028 & 12,504 & 25532 \\
\hline Junior & 10 & 3,672 & 3.564 & 7236 \\
\hline Senior & 8 & 2,099 & 2,445 & 4544 \\
\hline Secondary & 22 & 3,871 & 3,663 & 7534 \\
\hline All-age & 13 & 620 & 564 & 1184 \\
\hline Special schools* & 8 & 581 & 260 & 841 \\
\hline Alternative program & 6 & 41 & 73 & 114 \\
\hline Total & 171 & 24,209 & 23,365 & 47,574 \\
\hline
\end{tabular}

Source: Bahamian Education System, 2017 * Special Schools include schools designated as 'SURE', schools for the blind and deaf and 'Exceptional Schools

\section{Damage}

Damage to the 36 affected schools ranged from minimal to moderate, except for the all-age school on Ragged Island, which was destroyed. Many schools throughout the islands only received mild roof damage, general water damage, or shingle loss. The estimated effects to schools on all the affected islands is $\$ 1.5$ million (Table 19). The destroyed school at Ragged Island accounted for the single largest source at an estimated \$0.2 million.

The estimated cost to replace the school on Ragged Island is $\$ 80,000-\$ 90,000$. The eight children serviced by the all-age school are currently attending classes at schools on other islands. At the time of the report, The Bahamas' government has not yet decided about the replacement of the school on the island. 
Table 19 - Estimated Damage to Education Facilities by Island

\begin{tabular}{|l|r|r|r|}
\hline \multicolumn{1}{|c|}{ Island } & Total facilities & Facilities damaged & Total Damage \\
\hline Acklins & 4 & 4 & 130,488 \\
\hline Andros & 19 & 9 & 509,775 \\
\hline Bimini & 2 & 2 & 39,925 \\
\hline Crooked Is. & 2 & 2 & 19,564 \\
\hline Exuma & 13 & 1 & 37,100 \\
\hline Grand Bahama & 22 & 11 & 550,563 \\
\hline Inagua & 1 & 1 & 25,700 \\
\hline Long Is. & 7 & 4 & 51,613 \\
\hline Mayaguana & 2 & 1 & 9,388 \\
\hline Ragged Is. & 1 & 1 & 169,750 \\
\hline Total & $\mathbf{7 3}$ & $\mathbf{3 6}$ & $\mathbf{\$ 1 , 5 4 3 , 8 6 6}$ \\
\hline
\end{tabular}

Source: Assessment team

The damage to four schools on Acklins is estimated at over \$0.1 million. The schools experienced varied amounts roof damage. A site visit was made to the Central Secondary School on Acklins. Foremost was the destruction of the school's water tank by Hurricane Irma and the subsequent theft of the attached pump. The tank and pump were attached to a water well that was contaminated and needed cleaning before classes resumed.

The school's campus consists of an administrative building, a large classroom building, a small block of classrooms, and a structure containing the restrooms for students and teachers. There was also a gazebo used for assembly. The large classroom building suffered minor roof damage, however this led to leaking and subsequent water damage of the inner ceiling. The floor of the large school building also showed signs of sinking, which may be unrelated to the effects of the storm but can be aggravated should there be flooding around the building. The small block of classrooms received only minor roof damage with only a few shingles being lost to strong winds. It is of note that the roof was recently replaced after being seriously affected by hurricane Joaquin in the year 2015.

The administrative building received moderate effects, causing damage to the school's supplies storage as well as one of the air-conditioning units. One of the doors of the water closet was blown off and considerable damage was observed inside the structure. The gazebo used for assembly was shaken off its foundation and tilted, it is likely that it will not withstand moderate wind and is currently off limits. Overall damage to the school campus was estimated to be about $\$ 70,000$.

The only all-age school on Inagua is comprised of an administrative building and two classroom buildings, one for primary school students and the other for secondary school students. The building previously used for secondary school students had been unfit for some time, and as such classes had been attended in a rented church building opposite the school campus. This unused building was seriously damaged by the hurricane- mainly to the roof. The administrative building received damage to the roof, including shingle loss and minor water damage. 
The school's fence was destroyed, and debris was scattered in the schoolyard. An estimate of the damage was put at \$25,700. The Louise McDonald High School on Bimini sustained only minor damage with costs totaling to less than $\$ 1,000$. Similarly, the primary school on the island received only minor damage.

\section{Losses}

Losses in this sector refer to affected flows such as the reduction in hours or days of classes taught. All schools throughout The Bahamas were closed from 6 September to 11 September, following the hurricane. There were a few exceptions on the affected islands where school closures were extended due to damage; this increased the number of hours of education lost (Table 20).

Table 20 - School Closures Beyond 12 September 2017

\begin{tabular}{|l|r|r|r|r|}
\hline \multicolumn{1}{|c|}{ School } & Students & Teachers & Island & Reopen Date \\
\hline Deep Creek Preschool & 14 & 1 & Andros & Sept 14 \\
\hline Cleora McKenzie Preschool & 25 & 1 & Andros & Sept 14 \\
\hline Euthal Rodgers Primary & 61 & 5 & Andros & Sept 14 \\
\hline High Rock Primary & 101 & 5 & Andros & Sept 14 \\
\hline South Andros High & 129 & 24 & Andros & Sept 14 \\
\hline Victoria Point Preschool & 30 & 2 & Andros & Sept 14 \\
\hline Burnt Rock Primary & 81 & 5 & Andros & Sept 14 \\
\hline Mangrove Cay High & 97 & 14 & Andros & Sept 14 \\
\hline Bimini Primary & 132 & 7 & Bimini & Sept 18 \\
\hline Louise McDonald High & 84 & 14 & Bimini & Sept 18 \\
\hline Ulric Ferguson Primary & 18 & 3 & Crooked & Sept 18 \\
\hline Inagua All-Age & 159 & 16 & Inagua & Sept 18 \\
\hline Abraham's Bay High & 14 & 7 & Mayaguana & Sept 18 \\
\hline Salina Point Primary & 17 & 2 & Acklins & Closed \\
\hline Snug Corner Primary & 52 & 2 & Acklins & Closed \\
\hline Lovely Bay Primary & 6 & 2 & Acklins & Closed \\
\hline Acklins Central High & 16 & Acklins & Closed \\
\hline Ragged Island All-Age & & 2 & destroyed \\
\hline
\end{tabular}

Source: Bahamian Education System, 2017 * closed refers to schools closed at the time of the site visit of the disaster assessment team during 25 - 30 September 2017.

Because public education does not have a market price, losses were estimated using the cost of remuneration for teachers and number of hours of education lost. An average value of \$34,976 per year was used for preschool and primary school teachers, while an average of \$34,271 was used for secondary school 
teachers. The number of hours of education lost was estimated using a school schedule of 8:45 to 15:00 hours. Thus, there were losses of \$1.2 million for the schools that were able to reopen on 11 September. Total losses to the education sector were estimated to be $\$ 1.5$ million.

Table 21 - Summary of Losses in the Education Sector

\begin{tabular}{|c|c|c|c|}
\hline Island & Total facilities & Facilities Damaged & Total Losses \\
\hline Acklins & 4 & 4 & 29,564 \\
\hline Andros & 19 & 9 & 44,273 \\
\hline Bimini & 2 & 2 & 17,253 \\
\hline Crooked Is. & 2 & 2 & 4.946 \\
\hline Exuma & 13 & 1 & 833 \\
\hline Grand Bahama & 22 & 11 & 149,398 \\
\hline Inagua & 1 & 1 & 13,325 \\
\hline Long Is. & 7 & 4 & 10,826 \\
\hline Mayaguana & 2 & 1 & 5.712 \\
\hline Ragged Is. & 1 & 1 & 2,707 \\
\hline Unaffected facilities* & 98 & 0 & $1,235,849$ \\
\hline Total & 171 & 36 & $\$ 1,514,686$ \\
\hline
\end{tabular}

Source: Assessment team Undamaged facilities are all remaining schools, including those from New Providence, that were closed for 4 days because of the storm.

Throughout the islands there were cases where schools were not able to resume as expected, leading to increased losses due to loss of teaching hours. In Acklins, for example, the tank and pump that were attached to a water well was contaminated and in need of cleaning before school could resume. There was also an infestation of mosquitos at a few school campuses on Acklins, as with many other locations around the island where water had settled- the need for fumigation was also a factor that delayed schools from reopening. The all-age school on Inagua lost teaching time as it awaited the repair and cleaning of the church building that was being rented for some of its classes. In the case of the high school at Bimini, the principal noted that the school could have reopened on Tuesday 12 September, however the island was still evacuated of the students. Flights returned students to the island beginning Friday 15 September, allowing school to begin the following Monday. This example shows that evacuation exercises must be carefully planned considering the potential loss of class time by students; it is however also important that safety is the highest priority throughout the planning process. 


\section{Additional Costs}

The total estimate for Additional costs in the education subsector is \$20,900 (Table 22). These costs consider removal of rubble, clean-up activities, and other expenses to restore education services promptly. At the high school in Acklins, the costs came in the form of cleaning the school's water well and the fumigation of the school's campus from mosquitos.

Table 22 - Summary of Additional Costs in the Education Sector

\begin{tabular}{|l|r|}
\multicolumn{1}{c|}{ Description } & Cost \\
\hline Debris removal & 17,000 \\
\hline Miscellaneous costs & 3,900 \\
\hline Total & $\$ \mathbf{2 0 , 9 0 0}$ \\
\hline
\end{tabular}

The estimate of Additional costs also accounts for the bulldozing of the school on Ragged Island. In many cases, teachers and parents assumed the task of cleaning the facilities in their communities. In addition, many teachers volunteered to teach extra hours to ensure that students can prepare for upcoming examinations. 


\section{Health}

\section{Introduction}

The health sector suffered minor effects from Hurricane Irma. Ragged Island, the most severely affected territory, sustained moderate damage to its local clinic.. Minor structural damage was observed in health facilities in Inagua, Acklins, Bimini and Grand Bahama. The latter is the country's second most populated island and is host to the Rand Memorial Hospital in the city of Freeport. Minor damage was also reported at the Princess Margaret Hospital; the Bahamas' largest health care facility located in Nassau, New Providence.

The total cost of Hurricane Irma for the country's health sector was estimated at \$1.3 million; largely attributed to losses due to service disruption and additional expenses. The cost of the damage sustained by the impact of Irma was estimated at \$0.7 million. Most damage was caused by wind and, to a lesser extent, water intrusion. These estimates were projected from limited data sources and, with a few exceptions, do not reflect the actual payments incurred by the government. Estimates were mostly based on assessed damages and the relative size of services.

This report is limited to the public health care sector. The country's capital, Nassau, hosts one private hospital facility: Doctor's Hospital. There are several private clinics across the country, mostly situated in New Providence and Grand Bahama.

Four sources of information were used to compile data for this chapter:

1. Data collected by the Emergency Operations Centre (EOC) of the Bahamas Ministry of Health $(\mathrm{MOH})$ during and after the impact of Hurricane Irma.

2. Data provided by the Public Hospital Authority (PHA), including estimations from Princess Margaret Hospital, Sandilands Rehabilitation Centre, and the Grand Bahama Health System.

3. Data obtained from direct assessments of clinics in the three Family Islands (Ragged Island, Acklins, and Bimini) inspected by PAHO staff.

4. The Assessment of the Effect and Impact of Hurricane Matthew on The Bahamas, conducted by IDB, ECLAC, PAHO and FAO in 2016.

\section{Baseline Information}

For the purpose of this report, the term clinic identifies any health care facility that provides ambulatory care, and hospital is used to describe facilities with inpatient services. 
The Bahamas' public health infrastructure is composed of 3 inpatient hospital facilities and 80 clinics, providing ambulatory health care services across the 17 main inhabited islands. The distribution of clinics by island is shown in Table 23. Public hospitals are under the direct administration of the Public Hospital Authority, which is part of the Ministry of Health. Ambulatory clinics are under jurisdictional administration of the Department of Public Health; also a part of the Ministry of Health. However, ambulatory clinics in the Island of Grand Bahama are overseen by the Public Hospital Authority. Table 24 lists locations of the three public hospitals in the Bahamas.

Table 23 - Distribution of public clinics in The Bahamas by island

\begin{tabular}{|l|r|}
\hline \multicolumn{1}{|c|}{ Island } & Clinics \\
\hline Abaco & 8 \\
\hline Acklins & 5 \\
\hline Andros & 8 \\
\hline Berry Islands & 1 \\
\hline Bimini & 1 \\
\hline Cat Island & 3 \\
\hline Crooked Island & 2 \\
\hline Eleuthera & 14 \\
\hline Exuma & 4 \\
\hline Grand Bahama & 10 \\
\hline Inagua & 1 \\
\hline Long Island & 5 \\
\hline Mayaguana & 1 \\
\hline New Providence & 14 \\
\hline Ragged Island & 1 \\
\hline Rum Cay & 1 \\
\hline San Salvador & $\mathbf{8 0}$ \\
\hline Total & Source: Assessment team \\
\hline
\end{tabular}

Table 24 - Public hospitals in The Bahamas

\begin{tabular}{|l|r|}
\multicolumn{1}{|c|}{ Public Hospitals } & Location \\
\hline Princess Margaret Hospital & Nassau \\
Sandilands Rehabilitation Centre & Nassau \\
Rand Memorial Hospital & Freeport \\
& Source: Assessment team
\end{tabular}




\section{Damage}

\section{Damage to Public Clinics and Hospitals}

Hurricane Irma damaged a limited number of health care facilities in the Bahamas; the extent of which is detailed in Table 25. The scores used to report the scale of the damage, adapted from the USAID Initial Damage Assessment Scale, is explained in Table 26. Ten clinics sustained minor damage, while the clinic in Ragged Island sustained moderate damage. Further, two of the three public hospitals in The Bahamas reported minor damage to their installations (Table 27).

It is worth noting that some facilities reported damages that remained unrepaired since the passage of Hurricane Matthew in 2016 (e.g.: Coconut Grove and West End). Only new damage directly attributable to Hurricane Irma is reported here.

Table 25 - Summary of damage to public health clinics by Hurricane Irma

\begin{tabular}{|c|c|c|c|}
\hline Healthcare Facility & Island & $\begin{array}{l}\text { Damage } \\
\text { Score }\end{array}$ & Description \\
\hline Delectable Bay & Acklins & $1 \mathrm{a}$ & Nurses' residence roof damage. \\
\hline Salina Point & Acklins & $1 b$ & $\begin{array}{l}\text { Substantial water damage to ceiling with } \\
\text { fallen tiles. }\end{array}$ \\
\hline $\begin{array}{l}\text { Bailey Town Community } \\
\text { Clinic (Alice Town) }\end{array}$ & Bimini & $1 a$ & $\begin{array}{l}\text { Scattered shingles lost from clinic. No } \\
\text { flooding or leakage reported. }\end{array}$ \\
\hline Colonel Hill & $\begin{array}{l}\text { Crooked } \\
\text { Island }\end{array}$ & $1 a$ & Leakage reported. \\
\hline Landrail Point & $\begin{array}{l}\text { Crooked } \\
\text { Island }\end{array}$ & $1 a$ & Some loss of shingles from clinic roof. \\
\hline Staniel Cay Clinic & Exuma & $1 \mathrm{a}$ & $\begin{array}{l}\text { Shingles missing from the roof's } \\
\text { southern side with minimal leaking. }\end{array}$ \\
\hline Eight Mile Rock Clinic & $\begin{array}{r}\text { Grand } \\
\text { Bahama }\end{array}$ & $1 a$ & $\begin{array}{l}\text { Two roof leaks located above x-ray and } \\
\text { dental corridor. Some guttering loss. }\end{array}$ \\
\hline Hawksbill Clinic & $\begin{array}{r}\text { Grand } \\
\text { Bahama }\end{array}$ & $1 a$ & Minor shingle damages. \\
\hline West End Clinic & $\begin{array}{r}\text { Grand } \\
\text { Bahama }\end{array}$ & $1 \mathrm{a}$ & $\begin{array}{l}\text { Noticeable shingle damage to new } \\
\text { clinic, nurses' and doctors' residences. }\end{array}$ \\
\hline Mathew Town Clinic & Inagua & $1 b$ & $\begin{array}{l}\text { Roof damage to clinic and residences. } \\
\text { Leaking, plywood exposure and minor } \\
\text { shingle loss should not compromise } \\
\text { services. }\end{array}$ \\
\hline Duncan Town Clinic & $\begin{array}{l}\text { Ragged } \\
\text { Island }\end{array}$ & 2 & $\begin{array}{l}\text { Significant damage to clinic, particularly } \\
\text { to roof and windows. Water damage } \\
\text { to furniture and equipment. Nurse's } \\
\text { vehicle damaged. Minimal damage } \\
\text { to medication and supplies. Insulin } \\
\text { compromised and vaccines evacuated. }\end{array}$ \\
\hline
\end{tabular}

Source: $\mathrm{PAHO}, \mathrm{MOH}$, and PHA disaster assessment teams. 
Table 26 - Damage Score Scale*.

\begin{tabular}{|c|c|c|}
\hline \multicolumn{3}{|r|}{ Damage: Impairment of the usefulness or value of the property. } \\
\hline Level 1 & & $\begin{array}{l}\text { Minor damage: Structure is usable and can be occupied. Repairs required } \\
\text { are minimal. Examples: Some shingles blown off roof or roof covering } \\
\text { loosened. Windows broken. }\end{array}$ \\
\hline & $1 a$ & Scattered shingle missing. No or minimal flooding. \\
\hline & $1 b$ & Significant shingle missing, leakage and minor to moderate flooding. \\
\hline & $1 \mathrm{C}$ & $\begin{array}{l}\text { Extensive shingle missing or roof covering loosened. Several leaking areas, } \\
\text { moderate to significant flooding. Windows broken. }\end{array}$ \\
\hline Level 2 & & $\begin{array}{l}\text { Moderate damage: Structure is usable and can be occupied after urgent } \\
\text { temporary measures are taken. Example: Portions of roof covering are } \\
\text { missing. Windows or doors are blown out. Structure shifted off foundations. }\end{array}$ \\
\hline Level 3 & & $\begin{array}{l}\text { Major damage: Structure is not useable and cannot be occupied until after } \\
\text { repairs are made. Example: Roof covering is blown off exposing interior of } \\
\text { structure. Windows and doors are missing and walls are damaged. }\end{array}$ \\
\hline Level 4 & & $\begin{array}{l}\text { Destroyed: Structure is not useable and cannot be repaired. Must be } \\
\text { rebuilt. Example: Walls are blown down. Structural instability. Foundations } \\
\text { collapsed. Total destruction. }\end{array}$ \\
\hline
\end{tabular}

Note: *Adapted from USAID Initial Damage Assessment Scale.

Table 27 - Summary of damage in public health facilities - Hospitals and others.

\begin{tabular}{|l|l|l|}
\hline \multicolumn{1}{|c|}{ Healthcare Facility } & \multicolumn{1}{|c|}{ Island } & \multicolumn{1}{|c|}{ Description } \\
\hline Rand Memorial Hospital & Grand Bahama & $\begin{array}{l}\text { Significant leaks in roof over doc- } \\
\text { tors' lounge and IT area. }\end{array}$ \\
\hline Princess Margaret Hospital & New Providence & $\begin{array}{l}\text { Roof damage on a portion of Male } \\
\text { Surgical 2. Fencing damage to a } \\
\text { portion of Legacy site. }\end{array}$ \\
\hline Sandilands Rehabilitation Centre & New Providence & No damage during Irma. \\
\hline
\end{tabular}

Source: $\mathrm{PAHO}, \mathrm{MOH}$, and $\mathrm{PHA}$ disaster assessment team.

The estimated damage in infrastructure to the health care sector in the Bahamas attributable to hurricane Irma has been estimated in \$710 thousand. Table 28 lists estimated costs of damage to the public health care facilities, including clinics and hospitals. Damage to clinic equipment was only reported for the Duncan Town Clinic in Ragged Island; the cost of which is included in this facility's total damage cost assessment. 
Table 28 - Damage in public health facilities attributed to Hurricane Irma.

\begin{tabular}{|l|r|r|}
\hline \multicolumn{1}{|c|}{ Health Facility } & Islands & \multicolumn{1}{|c|}{ Damage } \\
\hline Delectable Bay & Acklins & 15,000 \\
\hline Salina Point & Acklins & 50,000 \\
\hline Bailey Town Community Clinic (Alice Town Clinic) & Bimini & 15,000 \\
\hline Colonel Hill & Crooked Island & 15,000 \\
\hline Landrail Point & Crooked Island & 15,000 \\
\hline Staniel Cay Clinic & Grand Bahama & 15,000 \\
\hline Eight Mile Rock Clinic & Grand Bahama & 15,000 \\
\hline Hawksbill Clinic & Grand Bahama & 15,000 \\
\hline West End Clinic & Inagua & 15,000 \\
\hline Mathew Town Clinic & Ragged Island & 50,000 \\
\hline Duncan Town Clinic & Grand Bahama & 300,000 \\
\hline Rand Memorial Hospital & New Providence & 100,000 \\
\hline Princess Margaret Hospital & & 90,000 \\
\hline Total & & $\$ 710,000$ \\
\hline
\end{tabular}

Source: Assessment team using data from $\mathrm{PHA}$ and $\mathrm{MOH}$ data.

\section{Losses}

This section outlines losses incurred due to disruption in health services; including clinics, hospitals and other health services such as corporate operations at PHA and $\mathrm{MOH}$. Estimated losses are summarized in Table 29. A total of $\$ 449,815$ is the estimated cost of health services operations disruption. The disruption covers three time periods: before, during and after the hurricane.

Table 29 - Losses to disruption in health services due to Hurricane Irma.

\begin{tabular}{|l|r|}
\hline \multicolumn{1}{|c|}{ Service } & \multicolumn{1}{|c|}{ Losses } \\
\hline Clinics & 64,466 \\
\hline Hospitals & 352,044 \\
\hline Other health services & 33,305 \\
\hline Total & $\$ \mathbf{\$ 4 9 , 8 1 5}$ \\
\hline
\end{tabular}

Source: Assessment team using data from $\mathrm{PHA}$ and $\mathrm{MOH}$ data.

Pre-hurricane disruption of normal operations included: (1) reassignment of resources to prepare health facilities and services, and (2) personal preparations undertaken by health staff. This time was estimated at two days for the six islands evacuated: Mayaguana, Inagua, Crooked Island, Acklins, Long Island and Ragged Island; and half a day for public health care facilities in other islands and corporate operations. 
The second period of disruption was during the hurricane's passage. Since most of the islands were affected during the weekend, operational impact was modest. Only one day of services disruption for clinics in Andros and two for health care facilities in Grand Bahama were considered in this category. These islands felt the effects of the hurricane later due to their geographic location.

The third disruption period was after the departure of the hurricane and included time during which a facility's normal operations remained unrestored. With the exception of Ragged Island, no health care facility suspended their operations due to structural damage. Therefore, only two days of service disruption are considered for the evacuated islands, which account for the time to relocate and restore operations. The case of Duncan Town Clinic is special as inhabitants of Ragged Island (estimated at 60 people) were not relocated after Irma due to extensive damage to infrastructure. Therefore, the cost of disrupted services was not considered beyond two days. Damage to medications and supplies of this clinic were minor and are included in Table 28.

\section{Additional Costs}

This section describes additional costs to the public health sector as they relate to the emergency response and provision of temporary relief. Additional costs considered here include the operation of emergency operation centres at the $\mathrm{MOH}$ and the three national hospitals; the cost of operating emergency services in four clinics on the island of New Providence; in addition to expenses incurred to protect facilities against the storm. Additional costs were estimated at \$170,724 (Table 30).

Table 30 - Additional costs associated with emergency response to Hurricane Irma

\begin{tabular}{|l|r|r|r|r|}
\hline \multicolumn{1}{|c|}{ Service } & Expenses & $\begin{array}{c}\text { Emergency } \\
\text { Operations Centre }\end{array}$ & $\begin{array}{c}\text { Cost of Additional } \\
\text { Operation }\end{array}$ & \multicolumn{1}{c|}{ Total } \\
\hline Clinics & $\$ 35,421$ & $\$ 9,109$ & $\$ 44,530$ \\
\hline Hospitals & $\$ 79,345$ & $\$ 30,558$ & $\$ 594$ & $\$ 110,497$ \\
\hline Other services & & $\$ 15,697$ & & $\$ 15,697$ \\
\hline Total & $\mathbf{\$ 1 1 4 , 7 6 7}$ & $\mathbf{\$ 4 6 , 2 5 5}$ & $\mathbf{\$ 9 , 7 0 3}$ & $\mathbf{\$ 1 7 0 , 7 2 4}$ \\
\hline
\end{tabular}

Source: Assessment team using data from $\mathrm{PHA}$ and $\mathrm{MOH}$ data. 



\section{INFRASTRUCTURE SECTORS}




\section{Roads, Airports, Ports and Other Infrastructure}

\section{Introduction}

This section analyzes the effects and consequences of Hurricane Irma on the general infrastructure of the affected islands, including roads, ports, seawalls and airports on Ragged Island, Great Inagua, Acklins, Bimini and Grand Bahama. These resources are vital assets for economic and every other activity of each community and island. They allow the dynamism of tourism and commerce, internal and external- the main drivers of the economy of the region through land, sea and air transportation. Roads, ports and airports support specific activities such as fishing, commercial and residential developments, and more importantly tourism in the islands. They also provide primary access to any service required during an emergency.

Damage to this sector was caused primarily by surge flooding rather than wind, except for the airport terminal building on Ragged Island that was destroyed by the hurricane-force winds. During the inspection visit it was confirmed that effects of Hurricane Irma wind and surge affected roads, airports, seawalls, bridges, docks and fences in Inagua, Ragged Island, Bimini and Acklins. Grand Bahama presented minor effects on infrastructure caused by tornados which occurred days after Irma impacted The Bahamas Islands.

The estimated damage to this subsector is $\$ 10.3$ million. Additional costs related to infrastructure improvement and reconstruction, debris removal, fencing and other minor jobs is $\$ 4.5$ million and the losses due to storm surge effects in Bimini is estimated to be $\$ 2.2$ million, and it is also associated with damage to private docking facilities causing a service interruption at the $\mathrm{Re}-$ sort World Marina in North Bimini.

The information for this chapter was obtained from field trips, and confirmed in different meetings with the Ministry of Works and Urban Development, Ministry of Environment and Housing, National Emergency Management Agency (NEMA), Airport Authority and others.

\section{Baseline Information}

\section{Road Network}

According to the information available, approximately 2,718 kilometers (1,689 mi) of road in The Bahamas is classified as highway or main roads, and approximately 1,560 kilometers $(970 \mathrm{mi}$ ) are paved. There are almost 1,000 km of roads on New Providence (some of which are privately owned), $209 \mathrm{~km}$ of roads on Eleuthera, $156 \mathrm{~km}$ on Grand Bahama, and more than $885 \mathrm{~km}$ on the Out Islands. Field inspections of roads revealed some deficiencies in construction standards and methods that are unsuitable for the zones in which they are 
located due to the exposure to flooding and exposed areas. As illustrated in Image 1, vulnerability prior to the disaster was considered high in the country for the following reasons:
A. Lack of a consistent design and construction standards and methods
B. Insufficient technical supervision during construction to ensure a cor- rect outcome
C. Inefficient and low quality structural components and construction deficiencies
D. Use of inappropriate materials given the local hazards and environment, causing the structure to deteriorate and become unable to withstand the effects of natural events
E. Absence of proper draining channels and systems to conduct rainfall adequately

Image 1 - Pavement structure and draining problems, in Acklins and Great Inagua Islands.
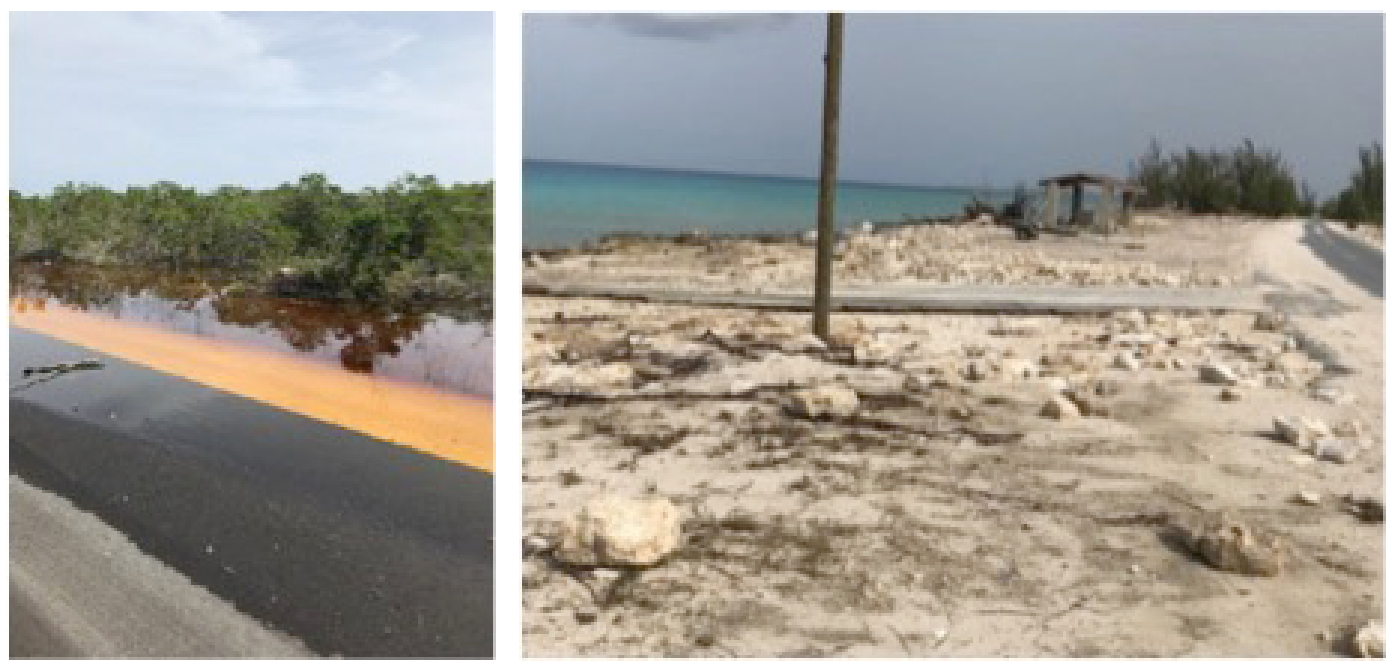

Source: Assessment team

\subsection{Airports}

One of the three main airports in The Bahamas is included on this assessment report: Grand Bahama International Airport. Also included are the airports on Ragged Island (DCT), Great Inagua (IGA), Acklins (AXP), and Bimini (BIM), as well as the West Airport in Grand Bahama (Table 31). 
Table 31 - Airport Runways on Affected Islands

\begin{tabular}{|c|c|c|c|c|c|c|}
\hline \multirow[t]{2}{*}{ Airport } & \multicolumn{2}{|c|}{$\begin{array}{l}\text { Runway } \\
\text { Length }\end{array}$} & $\begin{array}{l}\text { Elevation } \\
\text { (ft.) }\end{array}$ & Condition & Finish & $\begin{array}{l}\text { Per cent of } \\
\text { Affectation }\end{array}$ \\
\hline & (m) & (ft.) & & & & \\
\hline Ragged Island & 1,158 & 3,799 & 6 & Fair & Asphalt surface & $40 \%$ \\
\hline Great Inagua & 2,138 & 7,014 & 8 & Good & Asphalt surface & NA \\
\hline Bimini & 1,655 & 5,430 & 10 & Good & Asphalt surface & NA \\
\hline Acklins & 1,524 & 5,000 & 11 & Good & Asphalt surface & NA \\
\hline Grand Bahama & & & & & & NA \\
\hline West Airport & 2,438 & 7.999 & 5 & Fair & Asphalt surface & NA \\
\hline GBIA & 3.359 & 11,020 & 7 & Good & Asphalt surface & NA \\
\hline
\end{tabular}

NA $=$ Not affected

All airports have paved runways, six of them did not suffer any damage as a direct consequence of Hurricane Irma. In general, the terminal buildings (if any) and administration offices suffered minor effects to the roof cover and ceilings throughout the structure. The roofs are shingled, the ceilings have suspended light supports in internal offices, and an alternate ceiling system exists for outdoors.

Duncan Town Airport on Ragged Island is the only airport facility of the report that suffered damage to its runway and terminal building. It is important to address in this chapter that critical public buildings such as airports, hospitals and schools among other should be subject to more resilient and rigorous design standards in order to provide adequate service to the population but more importantly to support emergency response situations as well as serve a potential shelter and provide a safe evacuation process. In Image 2 we present the Ragged Island terminal building before the storm and a potential resilient solution (prefab building) to support our statement. The next section presents detailed information on the damage and the costs associated to the repairs and reconstruction efforts.

Image 2 - Ragged Island Airport Terminal / Resilient Prefabricated Solution.
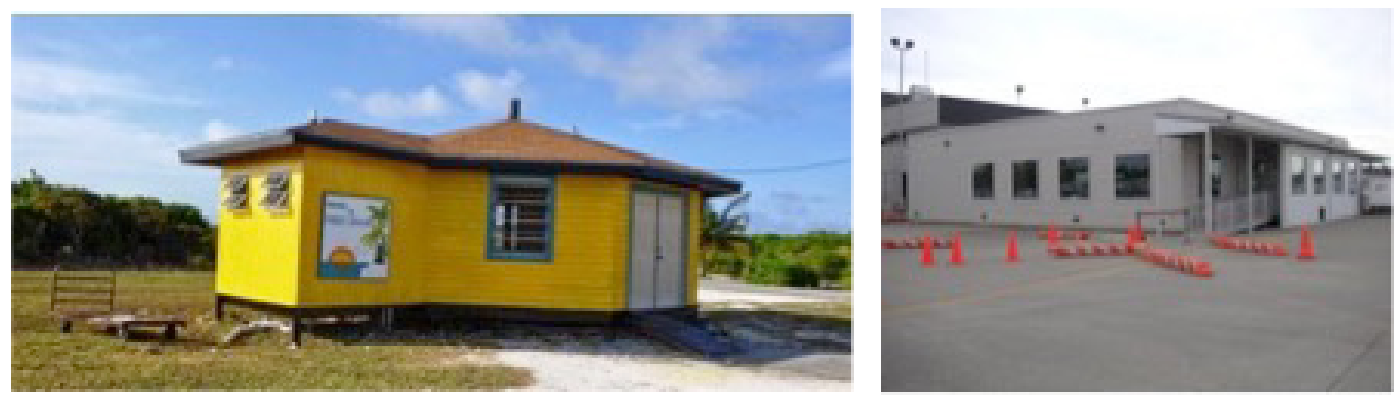

Source: Assessment team 


\subsection{Ports}

General marina activities are an aspect of significant importance for the economy of Bahamas, and tourism represents over 60 per cent of the Bahamian GDP. The islands assessed in this report have a significant group of commercial, fishing, and sporting ports that are critical to support the operation of collateral sectors. Image 3 shows a private marina on Bimini.

Image 3 - Resort World Marina (Bimini).

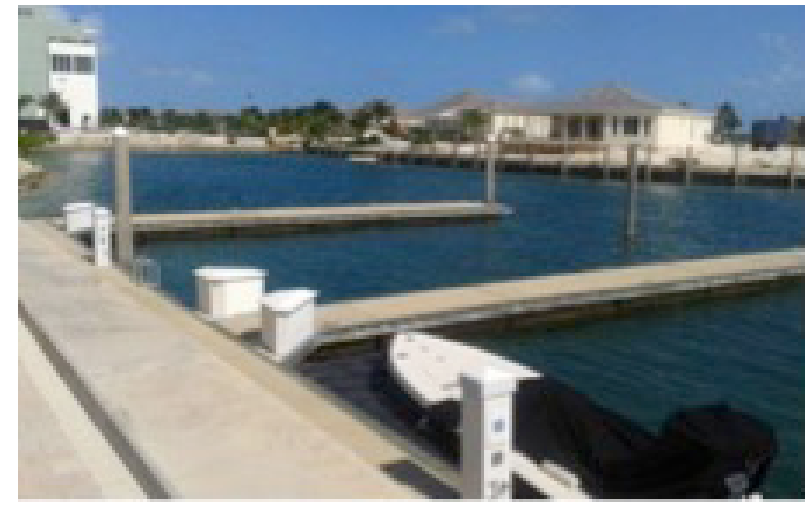

Source: Assessment team

\section{Damage}

Most of the damage to roads, ports, airports and seawalls from Hurricane Irma were reported on Ragged Island, Acklins, Inagua and Bimini. The affected infrastructure and its restoration are under the responsibility of The Ministry of Works and Urban Development and The National Emergency Management Agency. Both entities were also in charge of the coordination and the deployment of rapid response teams to ensure necessary and major infrastructures would be rehabilitated as soon as possible.

Table 32 - Estimated Total Damage, Losses, and Additional Costs

\begin{tabular}{|l|r|r|r|}
\hline & Damage & Losses & \multicolumn{1}{|c|}{ Additional Cost } \\
\hline Roads & $4,097,500$ & - & $1,573,818$ \\
\hline Airports & $2,683,400$ & - & $1,849,019$ \\
\hline Docks & $2,735,464$ & $2,213,269$ & $1,090,150$ \\
\hline Seawall & 826,875 & - & 19,688 \\
\hline Totals & $\mathbf{\$ 1 0 , 3 4 3 , 2 3 9}$ & $\mathbf{\$ 2 , 2 1 3 , 2 6 9}$ & $\mathbf{\$ 4 , 5 3 2 , 6 7 5}$ \\
\hline
\end{tabular}

Source: Assessment team 
Roads were affected mainly by excess water flow on surfaces because of storm surge, mostly on coastal proximities. This water flow deposited debris on the road and caused minor damage in the roadway. Severe drainage issues were observed in several roads, in particular on Acklins Island. During our assessment and site visits no damage to bridges was observed.

Hurricane Irma caused no major effects to airports. They mainly suffered minor roof and ceiling damage, with the exception of Ragged Island terminal building and runway. Seaports suffered minor damage on small dock structures, and considerable damage to Bimini ports was observed due to the sea surge and tide effect.

In general, port structures suffered minor damage to pillars and to decks made of concrete slabs for the small fishing docks. Also, as per the assessment team's inspection and interview with one of the private dock managers, the continuous and cyclical sea surge and tide impact caused severe damage in the infrastructure of the Resort World Marina in Bimini. The effects were the result of various aspects: 1) Potential noncompliance with structural criteria (Image 4); 2) Light floating structures that barely support the effects of these type of natural events 3) Construction materials that when damaged can subsequently create an environmental problem (Image 5). These facilities are critical to other important sectors, and should be designed and constructed considering rigorous codes and standards in order to support natural events of this nature, more in accordance with the resilient design observed in Great Inagua dock facilities (Image 6).

Image 4 - Damage on private dock facility at Bimini

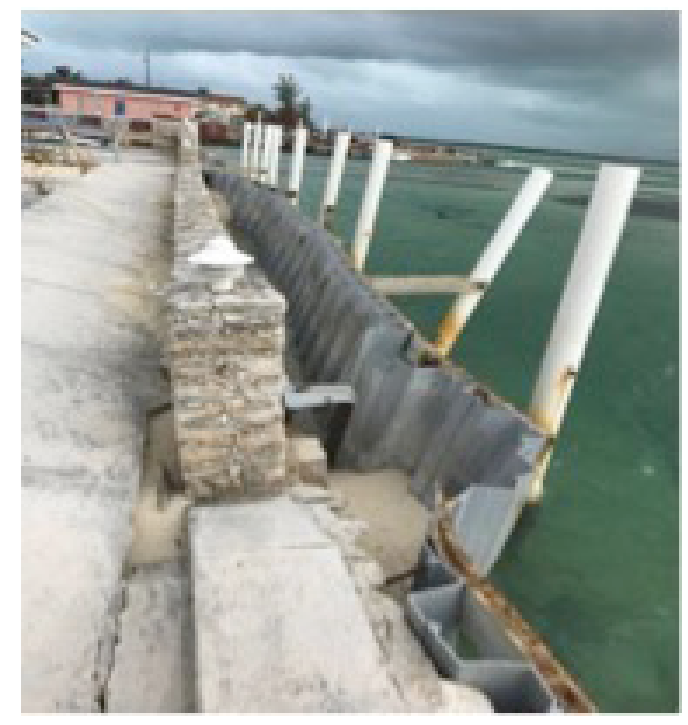

Source: Assessment team 


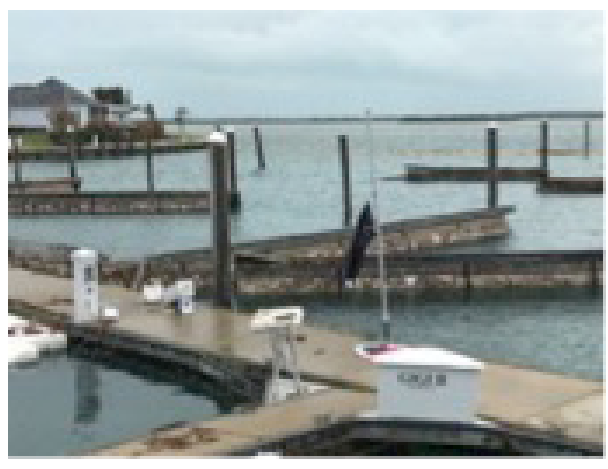

Image 6 - Dock in Great Inagua

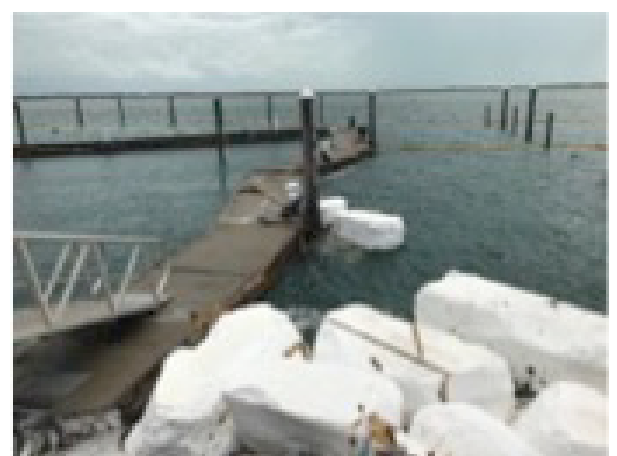

Source: Assessment team

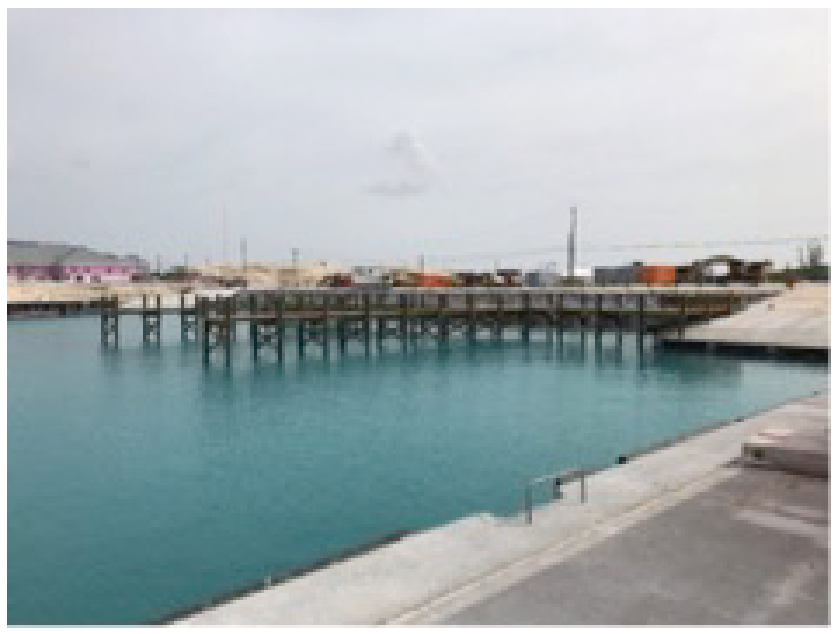

Source: Assessment team

It is considered one major impact of Hurricane Irma is its effect on the operation of the airports, ports and roads, which caused a reduction or loss of activity across all sectors. It is important that these infrastructures remain fully functioning to benefit The Bahamas.

\subsection{Road Network: Distribution, Access and Coastal Roads}

The hurricane affected mainly coastal highways and roads on these islands causing minor damage and debris removal on Ragged Island. Acklins and Inagua due to flooding and sea surge exposure. The properly paved coastal routes on these islands have lengths, respectively, of approximately 4.5, 54.4, and 6.9 miles $(7.2,86.9$, and $11 \mathrm{~km})$.

Hurricane Irma affected about $1.4 \mathrm{~km}$ of roads in Great Inagua and some road sections near to the coast at Acklins, with damage estimated at \$4.1 million. Special attention has to be paid to the new road in construction that links Spring Point Airport with Salina Point. It has several areas of concern due to the lack of a good drainage solution and the exposure to the sea surge. 
Table 33 - Damage to Roads

\begin{tabular}{|l|r|}
\hline \multicolumn{1}{|c|}{ Island } & \multicolumn{2}{|c|}{ Total } \\
\hline Ragged & 175,000 \\
\hline Great Inagua & 490,000 \\
\hline Bimini & - \\
\hline Acklins & $3,432,500$ \\
Grand Bahama & - \\
\hline Total & $\$ \mathbf{\$ 4 , 0 9 7 , 5 0 0}$ \\
\hline
\end{tabular}

Source: Assessment team

The road network is mainly paved, so most hurricane damage consisted of potholes formed by erosion due to heavy water flow as observed in Salina Point area (see Image 7). The absence of proper drain channels, sidewalk gutters, ditches, gutters and counterdrains generate excess water flow to damage the pavement structure at laterals. This allows water to run without restraint, causing it to reach and residences.

Image 7 - Damage in Roads at Salina Point, Acklins Island

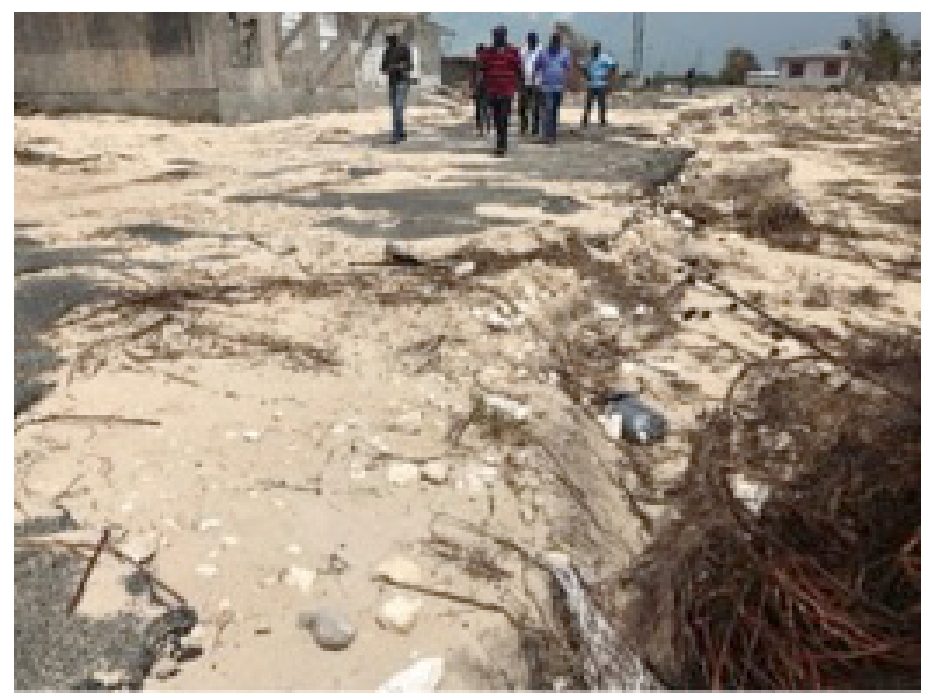

Source: Assessment team

It is important to evaluate areas for the potential for building storm water-retention ponds in strategic areas. Such ponds can regulate the delivery of rainfall to rivers, minimizing the risks of possible floods from excess water. Ideally, a storm water retention pond is designed so that the land vents at least 10 per cent less water flow than if in a normal undeveloped condition. This allows the region to start minimizing the impact of rain entering the river network throughout the country.

Roads along the coastline protected by a seawall suffered minor damage. Some seawalls were affected on Ragged Island, Great Inagua and Acklins (Table 34). In several seawall sectors, the top horizontal slab separated from the 
vertical wall and damage in the structure was observed in addition, other seawall areas were not executed according to the basic design and construction practices for a protection structure of this importance. This was seen as the implementation of temporary solutions to create defensive seawalls, often informally done by accumulating large natural rocks and laying them onto the existing beach material, as well as using non-resilient construction solutions, low quality materials, and the inadequate site construction supervision and inspection (Image 8). This creates an area of weakness in the shoreline by exposing the population to a non-resistant solution.

Image 8 - Seawall Damage Inspected in Great Inagua

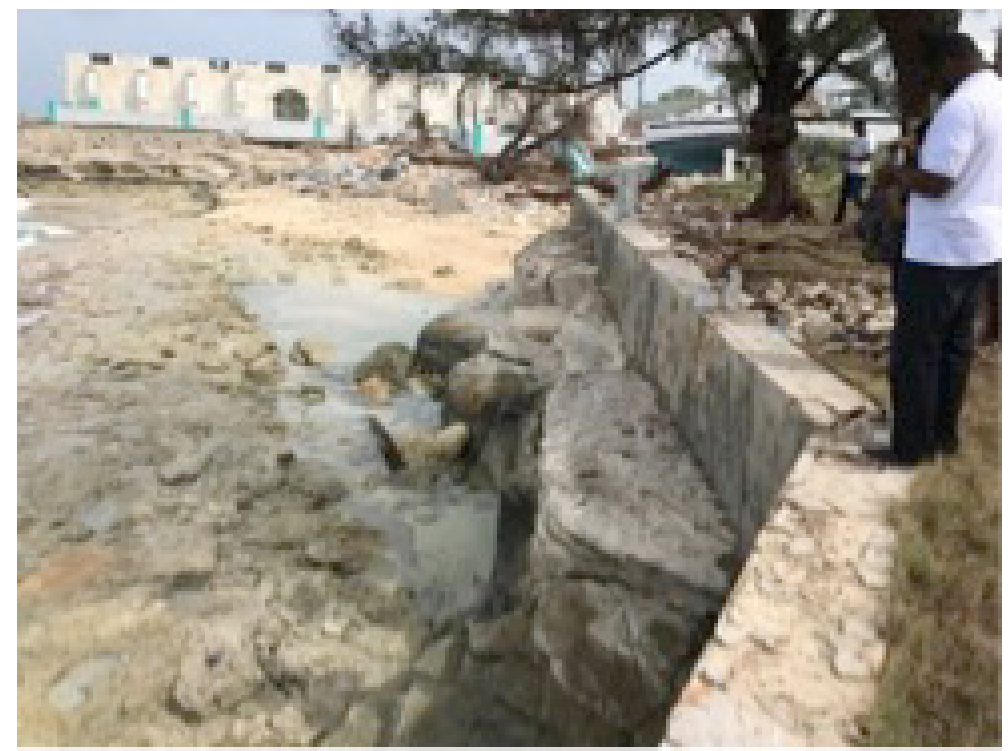

Source: Assessment team

The following table summarizes the damage to seawalls that were assessed during our mission.

Table 34 - Damage to Seawalls

\begin{tabular}{|l|r|}
\hline \multicolumn{1}{|c|}{ Island } & \multicolumn{1}{|c|}{ Total } \\
\hline Ragged Island & 236,250 \\
\hline Great Inagua & 378,000 \\
\hline Bimini & 70,875 \\
\hline Acklins & 141,750 \\
\hline Grand Bahama & \\
\hline Total & $\mathbf{\$ 8 2 6 , 8 7 5}$ \\
\hline
\end{tabular}

Source: Assessment team 


\subsection{Airports}

Damage to airports is estimated at \$2.7 million, see Table 35. Hurricane Irma caused no major effects to the main airports in The Bahamas. The Airports of Acklins, Great Inagua and Bimini mainly suffered roof and ceiling damage and some additional costs associated with debris removal and cleanup. The Ragged Island airport terminal structure collapsed, and damage to its runway pavement and the runway lighting system of Bimini airport was observed.

Table 35 - Damage to Airports

\begin{tabular}{|l|r|}
\hline \multicolumn{1}{|c|}{ Island } & \multicolumn{2}{|c|}{ Total } \\
\hline Ragged Island & $1,875,000$ \\
\hline Great Inagua & 377,000 \\
\hline Bimini & 350,000 \\
\hline Acklins & 36,400 \\
Grand Bahama & 45,000 \\
\hline Total & $\mathbf{\$ 2 , 6 8 3 , 4 0 0}$ \\
\hline
\end{tabular}

Source: Assessment team

Image 9 - Damage in the Ragged Island Airport Runway
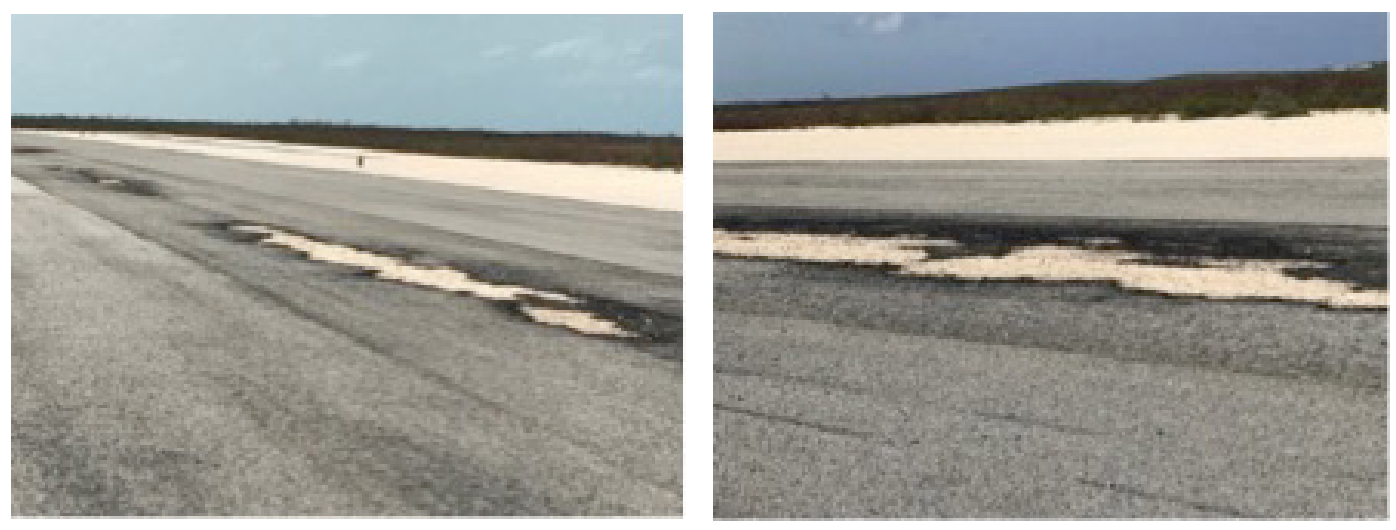

Source: Assessment team

Airport buildings sustained some roof damage, antenna and small sections of fencing were affected at the Great Inagua and Acklins Islands airports (Image 10). The Ragged Island airport building structure entirely collapsed due the force of Hurricane Irma wind forces (Image 11). It is important to point out that light structure construction and the apparent lack of improvements or maintenance creates a strategic facility extremely susceptible to natural events, and risks being disconnected to other sectors. 
Image 10 - Minor Damage at Great Inagua and Acklins Islands Airports
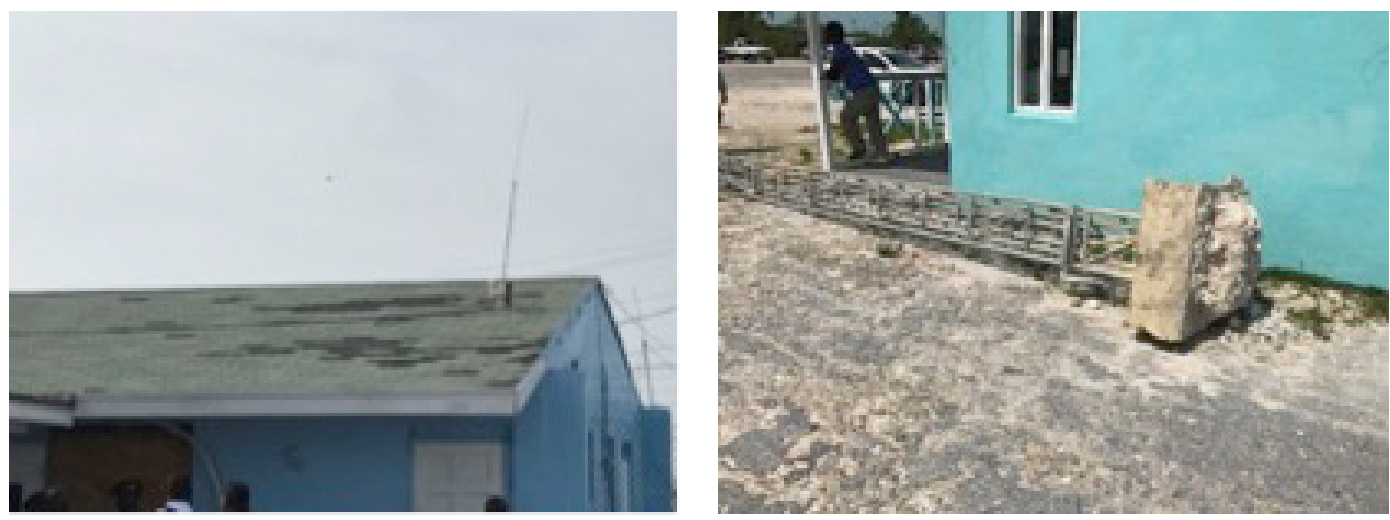

Source: Assessment team

Image $1 \mathbf{1}$ - Collapse of Ragged Island airport terminal

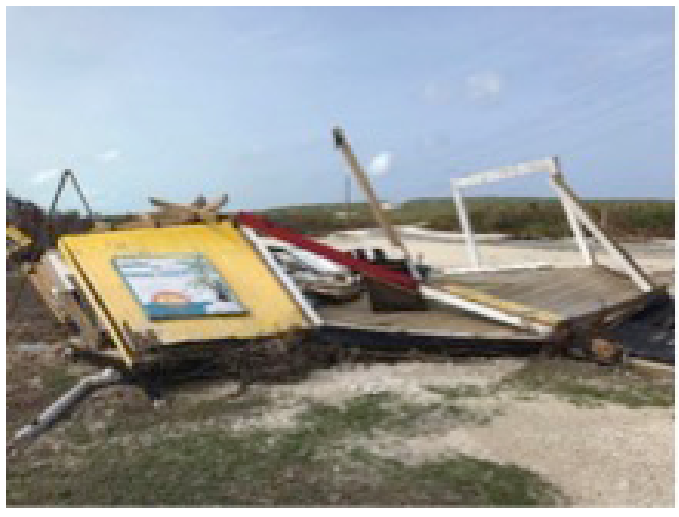

2.3 Docks

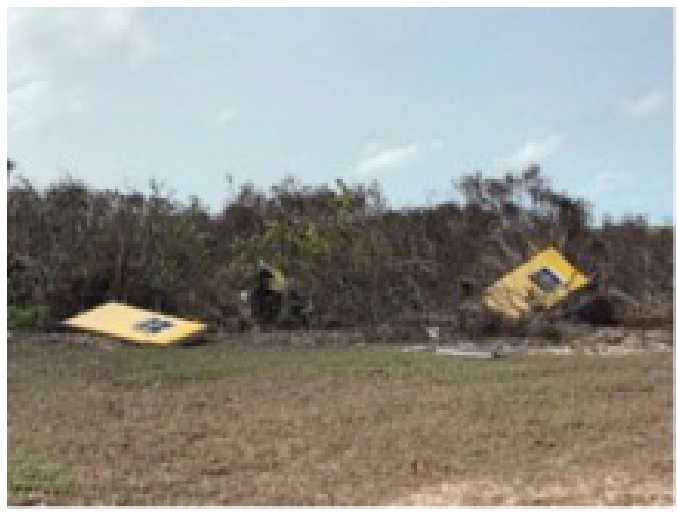

Source: Assessment team

Damage to docks is estimated to be \$2.7 million (Table 36). Hurricane Irma caused minor to moderate damage to the structure of the docks and auxiliary buildings as shown on the dock and small building in Ragged Island fishing dock on the west side of Duncan Town (Image 12). Vertical water pressure generated by storm surges damaged many small fishing facilities, and lateral flows also impacted each structure, with the effects being generated in some cases due to the low-quality design and poor construction practices.

Table 36 - Damage to Docks

\begin{tabular}{|l|r|}
\hline \multicolumn{1}{|c|}{ Island } & \multicolumn{1}{|c|}{ Total } \\
\hline Ragged & 128,489 \\
\hline Great Inagua & 47,150 \\
\hline Bimini & $2,507,775$ \\
\hline Acklins & 52,050 \\
Grand Bahama & 0 \\
\hline Total & $\mathbf{\$ 2 , 7 3 5 , 4 6 4}$ \\
\hline
\end{tabular}

Source: Assessment team 
Image 12 - Ragged Island Fishing Dock Damage

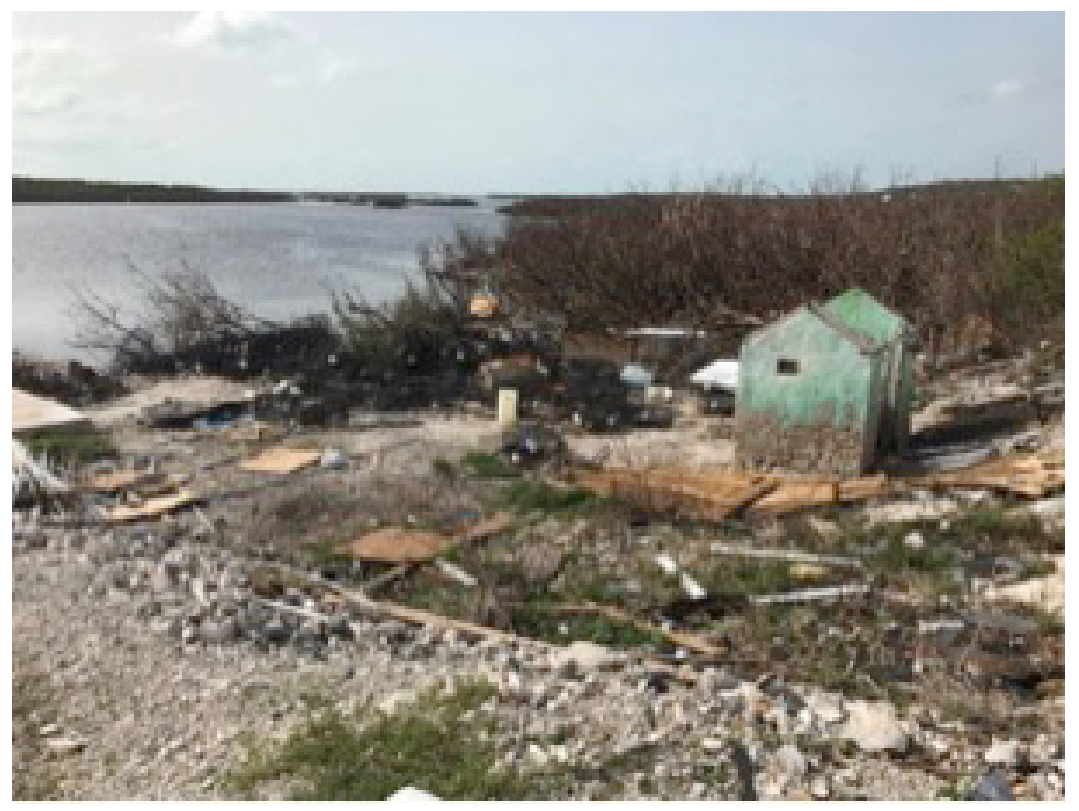

Source: Assessment team

On Bimini the Resort the World Marina was damaged. This affected the beaches and the surrounding environment due to the degradation and subsequent spreading of materials such as polystyrene foam in the surrounding waters (Image 13). Special considerations and evaluations of the reconstruction process should be taken to mitigate the risk of this situation in potential future events.

Image 13 - Styrofoam floating in the ocean in Bimini in September

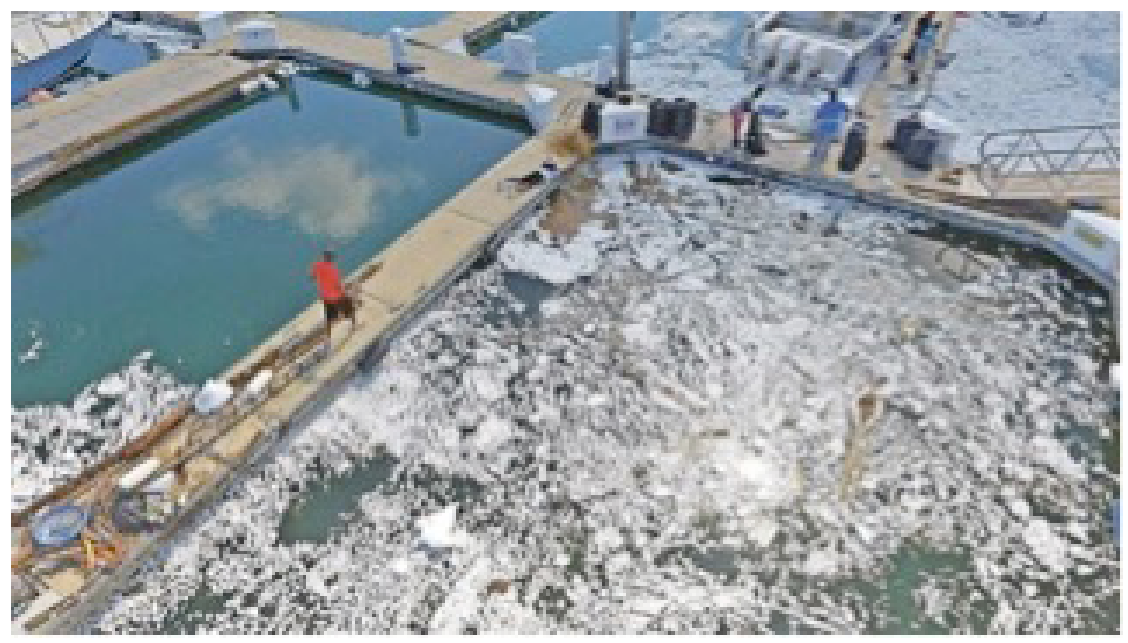

Source: Terrel W. Carey/Tribune 242 


\section{Losses}

Losses in this sector are related to the lasting effects of the event and the interruptions created which affected other important sectors, mainly tourism. Airports and ports had to be closed as part of the preparation process for receiving the hurricane as well as for several days after the event. These closures have a direct effect on the island's economy, and the relevant revenue losses are estimated in the tourism section with the exception of the losses created by the interruption of service at the Resort World Marina in Bimini. No revenue was lost as a result of road closures because no toll-related losses occurred on the visited islands. No motor vehicle infrastructure was affected. As mentioned in other sections of this report, most road damage was minor to moderate and did not present any revenue loss, according to site visits and information from local government institutions. No bridges were reported collapsed or affected enough to be catalogued as out of service, so no roads were closed for this reason.

Table 37 - Summary of Losses in the Roads, Airports, Ports, and Other Infrastructure Sector

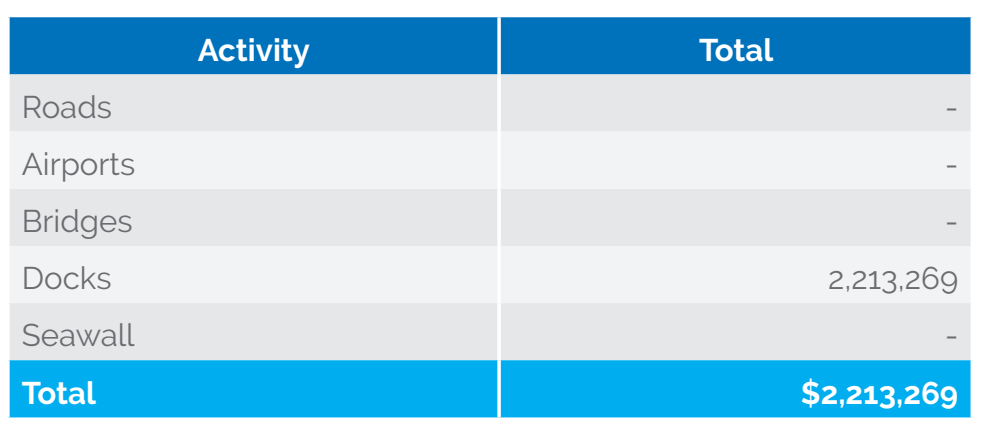

(*) Losses estimated until Dec. 2017 at Resort World Marina (Bimini) Source: Assessment team

\section{Additional Costs}

Additional costs in the roads, airports, ports, and other infrastructure sector is estimated at \$4.5 million. Costs included debris removal and the restoration of fencing built with galvanized wire. It is important to have an improved construction process for fence installation. In general, construction standards recommend welding every joint in the fence and pouring a small amount of concrete for pole installation. The concrete will serve as a small foundation for the fence system and increases the rigidity of the structure. 
Table 38 - Additional Costs in the Roads, Airports, Ports, and Other Infrastructure Sector

\begin{tabular}{|l|r|}
\hline \multicolumn{1}{|c|}{ Activity } & \multicolumn{1}{|c|}{ Total } \\
\hline Roads & $1,573,818.21$ \\
\hline Airports & $1,849,018.79$ \\
\hline Bridges & - \\
\hline Docks & $1,090,150.00$ \\
\hline Seawall & $19,687.50$ \\
\hline Total & $\mathbf{\$ 4 . 5 3 2 , 6 7 4 . 5 0}$ \\
\hline
\end{tabular}

Source: Assessment team 


\section{Telecommunications}

\section{Introduction}

In the telecommunications sector, Hurricane Irma caused downed communications lines and utility poles, loss of commercial power to mobile installations and cable nodes, rain and salt water-related damage to electrical equipment and buildings, and the breakage of undersea cables by drifting boats. Ragged Island suffered by far the most damage, followed by Grand Bahama, Inagua, Bimini and Andros.

Table 39 - Summary of Damage, Losses, and Additional Costs in the Telecommunications Sector

\begin{tabular}{|c|c|c|c|}
\hline Island & Damage & Losses & Additional Costs \\
\hline Abaco & 10,269 & 217 & 4,790 \\
\hline Acklins & 17,950 & 2,391 & 400 \\
\hline Andros & 87,881 & 13.518 & 1,600 \\
\hline Berry Islands & 6,000 & 0 & 0 \\
\hline Bimini & 163.714 & 17,553 & 1,500 \\
\hline Cat Island & 0 & 167 & 0 \\
\hline Crooked Island & 6,150 & 2,064 & 200 \\
\hline Eleuthera & 0 & 3,143 & 0 \\
\hline Exuma & 6,150 & 0 & 0 \\
\hline Grand Bahama & 210,740 & 54,449 & 152,036 \\
\hline Inagua & 153,662 & 2,103 & 141,248 \\
\hline Long Cay & 500 & 0 & 0 \\
\hline Long Island & 5,200 & 16,236 & 0 \\
\hline Mayaguana & 1,550 & 1,062 & 0 \\
\hline New Providence & 1,417 & 3.353 & 4,674 \\
\hline Ragged Island & $1,462,551$ & 1,831 & 143.772 \\
\hline Total & $\$ 2,133,734$ & $\$ 118,087$ & $\$ 450,220$ \\
\hline
\end{tabular}

Damage was estimated at \$2.1 million. Losses, standing for telecommunications sales forgone as a result of service outages, were estimated at \$0.1 million. The largest losses were in Grand Bahama, where over 2600 customers experienced service loss due to damage to overhead telecommunications cables, in part due to tornadic activity. Additional costs were estimated at \$0.5 million, reflecting the labor-related costs required to perform repairs, as well as generator fuel burned in the absence of commercial power. 
Data for this estimate was collected from interviews with staff of The Bahamas Telecommunications Company Ltd. (BTC) and Cable Bahamas, from public information sources, and from a preliminary estimate document provided by BTC. The country's recently-launched mobile carrier ALIV provided information indicating that their facilities had not sustained significant damage in the hurricane. A final estimate from BTC was not submitted, nor was a report from Cable Bahamas, and the lack of this information somewhat limits the accuracy of the values estimated in this sector.

\section{Baseline Information}

There are three primary players in The Bahamas' recently-liberalized telecommunications market - BTC, Cable Bahamas, and ALIV. BTC was at one time the national monopoly telecommunications carrier, and today provides fixed telephone, broadband internet, Internet Protocol Television(IPTV), and mobile services. It is 49 per cent owned by the Government of The Bahamas, and 49 per cent owned by Cable and Wireless, which is in turn owned by Liberty Global, and two per cent of BTC is owned by a charitable trust called the BTC Foundation. Many BTC products are provided under the FLOW brand name.

BTC is obligated by the terms of its license to provide telecommunications services throughout The Bahamas, and it has operations on 18 islands. The company has roughly 70,000 customers for fixed-line telecommunications services that use a combination of fiber optic and copper wire infrastructure. Up until ALIV entered the market in 2016, BTC was the monopoly provider of mobile communications services. BTC has about 284,000 mobile subscribers.

As a new entrant to the cellular market, ALIV is still in the process of building out its network in The Bahamas. As of August 2017, it had 142 cell sites in New Providence, Grand Bahama, Abaco, and Eleuthera, and provides service on other islands through infrastructure sharing agreements with BTC. The company is 48.25 per cent owned by Cable Bahamas, with the balance owned by a holding company that is currently controlled by the Government of The Bahamas.

Cable Bahamas provides cable television and broadband services in The Bahamas. The service they provide to islands is in three different tiers. In New Providence, Grand Bahama, Abaco, and Eleuthera they provide "triple-play" offerings including voice, television and broadband services, over networks that include both coaxial cable and fiber-to-the-home (FTTH) infrastructure. In eight smaller islands like Bimini, Long Island, at Inagua, the company operates head-end facilities that support stand-alone cable TV networks. In 11 of the smallest islands by population, such as Ragged Island and Acklins, the company co-locates antennas on BTC facilities, through which it provides six free, over-the-air broadcast channels.

The islands of The Bahamas are connected through an underwater fiber-optic cable network called The Bahamas Domestic Submarine Network (BDSNi), which has 14 landing points in the islands and an additional spur that connects to Port-au-Prince, Haiti. This submarine cable is owned and operated by BTC. 


\section{Damage}

Damage to telecommunications infrastructure was particularly sever in Ragged Island, which accounted for about 69 per cent of the total value of telecommunications damage in the country. Ariel cables were down throughout the island, and 28 poles needed to be replaced. The most damage- worth close to \$0.6 million- came from the destruction of electrical equipment used for data transport. This was affected because of damage to the roof of BTC's administration building, which allowed wind, rain, debris, and salt-spray to affect equipment housed inside, including co-located equipment owned by Cable Bahamas. In addition, the facility's generator house lost its roof completely, necessitating replacement of the generator, batteries, and fuse panels.

Grand Bahama and Bimini had the second and third-largest amount of damage among the islands. This was largely due to the tornados that affected the islands on 10 September, which resulted in extensive damage to copper and fiber-optic telecommunications lines. There was also damage to cellular equipment mounted on top of the Lucayan Towers in Grand Bahama. Over 2,600 fixed-line telecommunications customers lost service in Grand Bahama, and over 1,000 lost service in Bimini.

For its size, Inagua experienced a relatively high-level of damage. Over 7,600 feet of copper cable and 4,800 feet of fiber-optic cable had to be replaced, a Cable Bahamas satellite dish was destroyed, and cellular equipment located at the Morton Salt facility was affected.

Cellular antennas in Andros and Exuma were knocked out of alignment, and aerial cables in South Andros were damaged. There was moderate roof damage to BTC buildings in Long Cay and Crooked Island.

Near Abaco, there were two instances where boats damaged underwater data transmission cables. In one case, a boat was driven ashore near the landing point of a BDSNi cable, smashing repeatedly into the cable and breaking the fiber. In another case, a cable joint located nine miles out to sea from Marsh Harbour was found to be damaged. Locals reported that a large vessel had been seen in that area during the hurricane, and it is possible that the boat's anchor caused the damage.

The total damage to the Bahamian telecommunications subsector as a result of Hurricane Irma is estimated at \$2.1 million. This figure aggregates all damage reported by BTC and Cable Bahamas, as well as estimations on damage that was not reported. Figures for ALIV are not included, as that company reported no significant damage. 
Table 40 - Damage in the Telecommunications Sector

\begin{tabular}{|l|r|}
\hline \multicolumn{1}{|c|}{ Company } & Damage \\
\hline BTC & $1,865,594$ \\
Cable Bahamas & 268,139 \\
\hline Total & $\mathbf{\$} \quad \mathbf{2 , 1 3 3 , 7 3 3}$ \\
\hline
\end{tabular}

Source: Assessment team

\section{Losses}

Losses in the telecommunications sector were estimated at \$0.1 million. This relatively low figure reflects that most damage to telecommunications infrastructure occurred in lesser-populated areas. Those outages that affected large numbers of customers were resolved quickly. For example, there were largescale cable television outages in New Providence and Eleuthera but, in both cases, the problem was resolved in less than 12 hours. The only island that saw extended fixed-line outages lasting beyond three weeks after the storm was Ragged Island, but less than two dozen customers were affected.

Table 41 - Losses in the Telecommunications Sector

\begin{tabular}{|l|r|}
\hline \multicolumn{1}{|c|}{ Service } & \multicolumn{2}{|c|}{ Losses } \\
\hline Broadband internet & 36,757 \\
\hline Cable and IP television & 28,413 \\
\hline Cellular & 10,513 \\
Fixed telephone & 42,404 \\
\hline Total & $\mathbf{\$ 1 1 8 , 0 8 7}$ \\
\hline
\end{tabular}

Source: Assessment team

\section{Additional Costs}

Additional costs were estimated at \$0.5 million. Most of this figure reflects extraordinary labor and labor support costs required to make repairs to the network.

Table 42 - Additional Costs in the Telecommunications Sector

\begin{tabular}{|l|r|}
\hline & \multicolumn{1}{|c|}{ Additional Costs } \\
\hline Labor and labor support & 438,020 \\
\hline Generator fuel and servicing & 12,200 \\
\hline Total & $\$ \$ 450,220$ \\
\hline
\end{tabular}

Source: Assessment team

Costs like transportation and lodging for repair crews that travelled between islands are included in this figure. The cost of fueling and servicing generators is also included. 


\section{Introduction}

Damage from Hurricane Irma was primarily to transmission and distribution systems, and consisted of fallen power lines and utility poles, blown transformers, compromised insulators, and salt-spray accumulated on lines and equipment. Generation systems were not significantly affected.

While there were some cases where poles and lines were taken down by tornados- notably on Grand Bahama, Bimini, and Ragged Island- in most instances faults were caused by fallen trees or other debris. Electrical arching lead to damaged power lines, transformers, and insulators, and, in at least one case, caused a brush fire.

Damage was estimated at \$0.8 million. Losses, representing the amount of electricity that was not sold as a result of power outages, was estimated at \$0.4. Additional costs, consisting of overtime for staff and transport for repair crews and equipment, was estimated at \$0.7 million.

Data for this estimate was collected from an interview with staff of Bahamas Power and Light (BPL) and, with regard to the Grand Bahamas Power Company, information was compiled from public statements, media reports, and estimates concerning the impact of Hurricane Matthew in 2016.

Table 43 - Damage, Losses, and Additional Cost in the Power Sector, by Island

\begin{tabular}{|l|r|r|r|}
\hline \multicolumn{1}{|c|}{ Island } & Damage & Losses & Additional Costs \\
\hline Acklins & 42,516 & 6,765 & 63,773 \\
\hline Andros & 70,859 & 7,731 & 49,601 \\
\hline Bimini & 47,239 & 3,221 & - \\
\hline Crooked Island & 9,448 & 129 & - \\
\hline Exuma & 4,724 & 1,546 & - \\
\hline Grand Bahama & 283,437 & 368,877 & 28,344 \\
\hline Inagua & 103,927 & 10,308 & - \\
\hline Long Island & 14,172 & 129 & $\mathbf{1 0 3 , 9 2 7}$ \\
\hline Mayaguana & 33,068 & 5,154 & $\mathbf{6 6 , 1 3 5}$ \\
\hline New Providence & 23,620 & 19,236 & - \\
\hline Ragged Island & 188,958 & 5,798 & 377,916 \\
\hline Total & $\mathbf{\$ 8 2 1 , 9 6 8}$ & $\mathbf{\$ 4 2 8 , 8 9 4}$ & $\mathbf{\$ 6 8 9 , 6 9 6}$ \\
\hline
\end{tabular}

Source: Assessment team 


\section{Baseline information}

1. Baseline information

On most islands of The Bahamas, electrical power is provided through BPL. On the island of Grand Bahama, power is provided through the Grand Bahama Power Company (GBPC). Electricity in The Bahamas costs an average of \$ 0.32 per $\mathrm{kWh}$, which is split between a base tariff and a fuel surcharge.

As of 2016, GBPC had a total of 19,176 electricity customers, of which 15,650 were residential customers. That year, the company sold $296 \mathrm{gWh}$ of power- a number was depressed as a result of extended power outages associated with Hurricane Matthew. Sales for the two previous years averaged $330 \mathrm{gWh}$ each year, and it is this figure that is used as a baseline for the calculation of losses. GPBC is a private company, majority owned by Emera Ltd., a Canadian utility.

Bahamas Power and Light (BPL) serves 108,000 customers in New Providence and most of the Family Islands. The state-owned company was previously known as The Bahamas Electric Company (BEC), but changed names as part of a restructuring in 2015-2016. This restructuring also included the establishment of a management services agreement between the Government of The Bahamas and PowerSecure, an American company, to take over management of the re-christened BPL for a period of five years. However, after a rocky 18 months and a national election, this contract has been cancelled early, and there is heightened uncertainty about BPL's future.

\section{Damage}

Areas of New Providence were impacted by trees falling on lines. There were approximately 60 outages on the island, but most areas were unaffected by power loss. In general, damage was limited, in part because BPL has increased the resources devoted to tree-trimming operations in the year since Hurricane Matthew. However, there were some delays in restoration in cases where rights-of-way on private property were not made immediately available to BPL repair crews. These issues notwithstanding, New Providence was fully restored by September 10.

Of the Family Islands, the most affected were Ragged Island, where 28 poles were destroyed, and the entire distribution network had to be rebuilt, and Inagua, where 17 poles were destroyed, and 43 spans of conductor fell. South Andros and Mangrove Key together lost three high voltage poles and seven low voltage poles, and Bimini lost seven poles. Six poles were lost in Acklins, one pole was lost in Exuma and two were lost on Long Island.

In Mayaguana, 20 spans of conductor line fell as a result of Irma. BPL crews had been deployed to the island, but were pulled out on September 22, before repairs were completed, due to concern over the approach of Hurricane Maria. During Maria, two additional poles on the island caught fire and burned down. This was likely the result of electrical arching caused by an excess of salt spray that accumulated during both Irma and Maria, which compromised the effectiveness of the insulator between the cable and the pole. 
There was also at least one fire caused by electricity on Grand Bahama, (Image 14) where a brush fire was caused when conductor cables oscillating in the wind came in contact with the top branches of a nearby tree. This occurred on the afternoon of 10 September, the same day tornados touched down on the island. Nearly 50 poles on the island were damaged, mostly as a result of tornados, and around 10 PM the power grid shut down to protect itself from damage, sending Grand Bahama into a blackout. Unlike BPL in some of the southern islands, GBPC had opted not to perform a controlled shutdown prior to the storm. The island was 99 per cent re-energized within five days after the storm, though there was an additional delay caused by the need to rinse salt spray off of transmission lines and substation equipment.

Image 14 - Brush fire caused by contact between vegetation and power lines

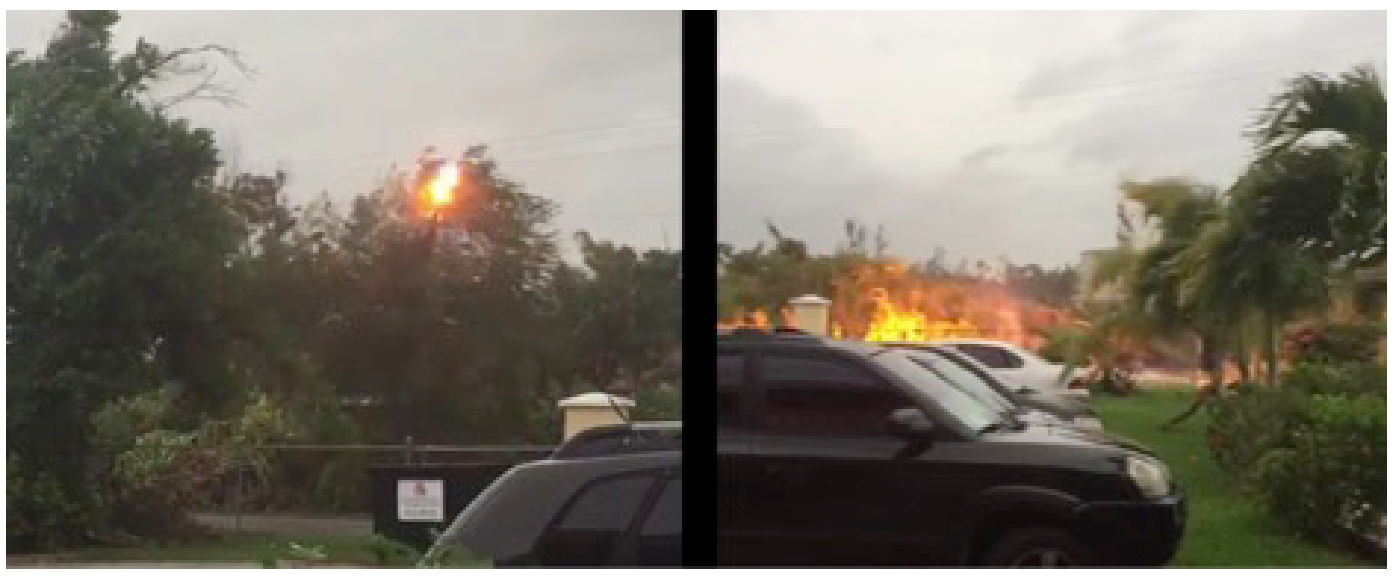

Source: Grand Bahama Power Company

In general, generation capacity was not affected as a result of the storm. Even on Ragged Island, despite damage to the building housing the generator, the generator itself was still operable after the storm. Damage associated with Hurricane Irma in The Bahamas is estimated at \$0.8 million.

Table 44 - Damage in the Power Sector

\begin{tabular}{|l|r|}
\hline \multicolumn{1}{|c|}{ Company } & \multicolumn{1}{|c|}{ Damage } \\
\hline Grand Bahamas Power Company & 283,438 \\
\hline Bahamas Power and Light & 538,530 \\
\hline Total & $\$ \$ 821,968$ \\
\hline
\end{tabular}

Source: Assessment team 


\section{Losses}

Losses represent the value of power not sold as a result of power outages associated with the storm. This number is estimated based on the number of customers affected by outages, and the length of time they were affected. The total value of losses was estimated at \$0.4 million, of which 86 per cent occurred on Grand Bahama as a result the island-wide power outage.

Table 45 - Losses in the Power Sector

\begin{tabular}{|l|r|}
\hline \multicolumn{1}{|c|}{ Company } & \multicolumn{1}{|c|}{ Losses } \\
\hline Grand Bahamas Power Company & 368,877 \\
\hline Bahamas Power and Light & 60,018 \\
\hline Total & $\$ \mathbf{4 2 8 , 8 9 5}$ \\
\hline
\end{tabular}

Source: Assessment team

\section{Additional costs}

Additional Costs include the cost of overtime and contracted labor to restore power infrastructure, as well as support costs such as transportation and lodging. These costs were highest on Ragged Island and Inagua, where crews had to be shipped in to repair extensive damage. Additional costs in the power sector were estimated at \$0.7 million.

Table 46 - Additional Costs in the Power Sector

\begin{tabular}{|l|r|}
\hline \multicolumn{1}{|c|}{ Company } & \multicolumn{2}{|c|}{ Costs } \\
\hline Grand Bahamas Power Company & 28,334 \\
\hline Bahamas Power and Light & 661,352 \\
\hline Total & $\$ \mathbf{\$ 6 9 , 6 9 6}$ \\
\hline
\end{tabular}

Source: Assessment team 


\section{Water and Sanitation}

\section{Introduction}

The interruption of power from Hurricane Irma prevented the generation and distribution of water. Diesel emergency generators were used to replace regular power in Acklins, Bimini, Inagua and Ragged Island. Distribution lines and residential connections were affected in Ragged Island and Salina Point. With the exception of the Ragged Island and Bimini underwater line, there was no substantial damage to the Water and Sewerage Corporation (WSC) facilities on any other Family Island.

Damage was approximately \$0.5 million due to the interruption of water distribution service into dwellings, it is estimated that losses were around \$0.9 million. Additional costs, estimated as \$3.3 million, refer to the expense of managing the debris that arrived at landfills, costs for disaster assessment and recovery teams deployed and payment to fulfill restoration work.

Information for this assessment was collected from damage reports and public information provided by WSC, interviews with staff and field visits to affected locations.

\section{Baseline information}

The Bahamas Water and Sewerage Corporation (WSC) reports to the Minister of Works \& Urban Development. WSC is wholly owned by The Bahamas Government. WSC is commended to provide water and sewerage in four of the island assessed. Grand Bahama Utility Co Ltd. is corporation commended to provide water to Grand Bahama.

WSC is responsible for storage and the distribution network, as well as billing and collection to the final customer. Most of the water comes from reverse osmosis plants where the water is treated from the sea, or from brackish water wells.

Table 47 - Water Supply in Private Dwellings, in The Bahamas

\begin{tabular}{|c|c|c|c|c|c|c|c|c|c|}
\hline Island & $\begin{array}{l}\text { Public } \\
\text { Piped } \\
\text { into } \\
\text { Dwelling }\end{array}$ & $\begin{array}{c}\text { Public } \\
\text { Piped } \\
\text { into } \\
\text { Yard }\end{array}$ & $\begin{array}{l}\text { Private } \\
\text { Piped } \\
\text { into } \\
\text { Dwelling }\end{array}$ & $\begin{array}{c}\text { Private } \\
\text { not } \\
\text { Piped }\end{array}$ & $\begin{array}{c}\text { Public } \\
\text { Stand } \\
\text { Pipe }\end{array}$ & $\begin{array}{l}\text { Public } \\
\text { Well } \\
\text { or } \\
\text { tank }\end{array}$ & $\begin{array}{c}\text { Rain } \\
\text { Water } \\
\text { System }\end{array}$ & Other & Total \\
\hline Acklins & 147 & 9 & 43 & 5 & 1 & 0 & 2 & 2 & 209 \\
\hline Bimini & 466 & 9 & 251 & 6 & 0 & 0 & 8 & 7 & 747 \\
\hline $\begin{array}{l}\text { Grand } \\
\text { Bahama }\end{array}$ & 13,755 & 137 & 1,081 & 72 & 6 & 0 & 4 & 55 & 15,110 \\
\hline Inagua & 296 & 0 & 2 & 1 & 0 & 0 & 10 & 5 & 314 \\
\hline Ragged & 10 & 7 & 2 & 0 & 2 & 0 & 5 & 0 & 26 \\
\hline Total & 14,674 & 162 & 1,379 & 84 & 9 & 0 & 29 & 69 & 16,406 \\
\hline
\end{tabular}

Source: Bahamas Statistics Department 2010 Census 
These water production plants are managed by third parties, for Salina Point in Acklins and Ragged Island the company with the concessions of these plants is Watermakers, Inc., they supply the water already treated to WSC to be distributed. The treated water is transported to the storage tanks, and then the water is distributed through the pipe network to the entire island.

According to the 2010 census, there are 14,674 dwellings connected directly to the public network (Table 47).

Grand Bahama is the only of the assessed islands that has a mass system of sewerage, while the other islands commonly use septic as a dwelling drainage system (Table 48).

Table 48 - Type of Sewerage System by Island

\begin{tabular}{|l|r|r|r|r|r|}
\hline \multicolumn{1}{|c|}{ Island } & Mass System Sewerage & Septic & Pit Latrine & Other & Total \\
\hline Acklins & - & 199 & 10 & - & 209 \\
\hline Bimini & - & 747 & - & - & 747 \\
\hline Grand Bahama & 1,602 & 13,443 & 23 & 42 & 15,110 \\
\hline Inagua & - & 309 & 5 & - & 314 \\
\hline Ragged & - & 20 & 6 & - & 26 \\
\hline Total & $\mathbf{1 , 6 0 2}$ & $\mathbf{1 4 , 7 1 8}$ & $\mathbf{4 4}$ & $\mathbf{4 2}$ & $\mathbf{1 6 , 4 0 6}$ \\
\hline
\end{tabular}

Source: Bahamas Statistics Department 2010 Census

\section{Damage}

Hurricane caused minimal damage to the water and sanitation sector in The Bahamas, with the exception of Ragged Island and Bimini. The Bimini underwater line and Ragged Island's desalination plant, including the storage tanks and distribution pumping system, suffered substantial damage. Damage in this sector is estimated to be close to \$0.5 million (Table 49).

Table 49 - Summary of Damage in the Water Sector

\begin{tabular}{|l|r|}
\hline \multicolumn{1}{|c|}{ Description } & \multicolumn{1}{c|}{ Amount } \\
\hline Acklins Distribution Network & 37,500 \\
\hline Bimini Underwater Line & 250,000 \\
\hline Ragged RO Plans & 26,800 \\
\hline Ragged Water Tanks & 7,800 \\
\hline Ragged Tank Roof & 5,600 \\
\hline Ragged Distribution Network & 37,500 \\
\hline Others & 110,000 \\
\hline Total & $\mathbf{\$ 4 7 5 , 2 0 0}$ \\
\hline
\end{tabular}

Source: Assessment team 


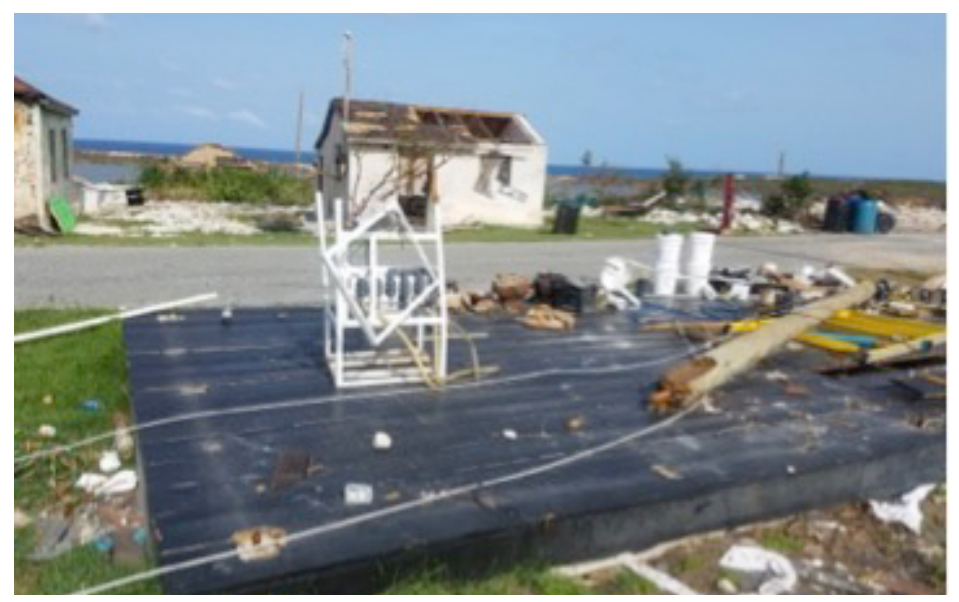

Source: Assessment team

\section{Losses}

In this sector losses are related to piped water service interruption, lack of production of water, and leakages in the system losing treated water. Electricity was interrupted for several days, interrupting the production of water through desalination plants and pumps. This was solved with diesel generators.

Table 50 - Summary of Losses in the Water and Sanitation Sector

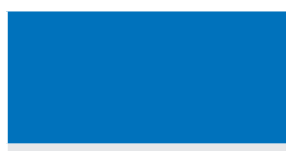

Acklins

Bimini

Inagua

Grand Bahama

Ragged

Total

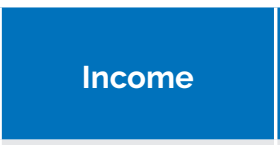

15,675

98,280

15.977

513,680

60,000

$\$ 703,612$
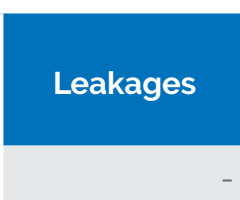

3,276

(1)

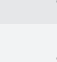

4,000

$\$ 7,276$

\section{Shortage of
Production}

5,225

32,760

5.325

171,226

1,500

216,036

\section{Total}

20,900

134,316

21,302

684,906

65.500

$\$ 926,924$

Source: Assessment team.

\section{Additional Costs}

Additional costs for water and sanitation are estimated to be $\$ 3.3$ million (Table 51). Costs include diesel and gas to power generators to operate pumps and desalination plants, acquisition of emergency generators, machinery needed to clean debris, hiring or contracting new workers or companies, paying overtime to workers repairing water pipelines, demolitions, and temporary facilities. 
Table 51 - Additional Costs in the Water and Sanitation Sector

\begin{tabular}{|l|r|r|r|}
\hline \multicolumn{1}{|c|}{ Island } & Extra Expenses & Debris Handling & Additional Costs \\
\hline Acklins & 39,400 & 864,000 & 903,400 \\
\hline Bimini & 98,280 & 645,750 & 744,030 \\
\hline Inagua & 39,400 & 576,000 & 615,400 \\
\hline Grand Bahama & - & 630,000 & 630,000 \\
\hline Ragged & 59,400 & 390,000 & 449,400 \\
\hline Total & $\mathbf{\$ 2 3 6 , 4 8 0}$ & $\mathbf{\$ 3 , 1 0 5 , 7 5 0}$ & $\mathbf{\$ 3 , 3 4 2 , 2 3 0}$ \\
\hline
\end{tabular}

Source: Assessment team. 


\section{PRODUCTIVE SECTORS}




\section{Tourism}

\section{Introduction}

Unlike previous storms, Irma did not directly affect major tourism infrastructure of The Bahamas. Regardless, it was a major storm that received extensive news coverage for days before making landfall, and it caused an important disruption in the flow of tourists all over the Caribbean. Irma affected The Bahamas similarly to Matthew in terms of losses, although with much less damage.

Irma caused extensive damage in some of the southern islands of the Lucayan Archipelago. The effects were particularly significant in Duncan Town, Matthew Town, and Salina Point. There was also important damage on Bimini due to water surge, and on Grand Bahama due to tornados.

The total damage in the tourism sector was \$0.6 million, mainly in the Out Islands. The losses are much greater, escalating to \$68 million. The additional costs were a little more than \$0.1 million. Most of the effects were concentrated in the bigger islands, although relatively the impact is greater for the smaller communities affected.

The information for this section comes from the fieldwork observation and interviews, from official institutions like the Ministry of Tourism, Ministry of Finance, The Central Bank of Bahamas and The Department of Statistics of The Government of The Bahamas, and private associations like The Bahamas Insurance Association.

\section{Baseline Information}

The tourism sector is the biggest in the Bahamian economy. In the past few years hurricanes have disrupted this sector. Fortunately, leaving aside some exceptions, the sector has recovered relatively fast after the events.

The year 2016 saw The Bahamas receive 4,690,374 cruise visitors, measured by first port of entry. For the first eight months of 2017 the country received $3,159,040$ cruise ship visitors, which represents a decline of 1.5 per cent with respect to the same period in 2016. This decline was in part due to lingering effects of Hurricane Matthew. According to our estimations, the total expenditure of cruise ship visitors during 2016, measured by third point of entry ${ }^{13}$, was $\$ 325$ million. Almost 80 per cent of this expenditure was done in New Providence, 13.7 per cent in Grand Bahama, and the remainder in the Out Islands.

In addition to cruise ship visitors, the country has well developed hotels and resorts to receive stopover visitors. During 2016, The Bahamas hosted 1,481,832 of these visitors. During the first eight months of 2017, according to our estimations, the country received 1,066,148 total stopover visitors, down 6 per cent with respect to the same period of 2016. This decline is heavily influenced by the decline in this type of tourism in Grand Bahama, although, in New Providence there were fewer stopover visitors as well. 
According to our estimations, stopover visitors during 2016 generated a total of \$2.25 billion. Of those around \$1.58 billion were spent in New Providence, \$174 million in Grand Bahama, and \$503 million in the Out Islands. The Bahamas also received around 47,500 single-day visitors that generated \$2.7 million.

For the year 2016 The Bahamas received a total of 6,219,699 visitors, who spent a total of $\$ 2.58$ billion. Most of the business is done in Nassau and Providence Island. In terms of room capacity, in 2016 there were 8,006 rooms in New Providence, 2,307 in Grand Bahama and 4,491 in the Out Islands. Room capacity is likely to have increased in Nassau due to the soft opening of Baha Mar, but diminished in Grand Bahama due to the fact that Grand Lucayan Resort and Memories Grand Bahama did not recover from Matthew. According to our estimations, this put the room capacity in Grand Bahamas at around 1,558 rooms.

\section{Damage}

Most of The Bahamas tourism infrastructure is in the northern islands of the archipelago, New Providence and Grand Bahamas being the most developed. Unlike Matthew, Irma did not directly impact these islands. There were tornados reported in Grand Bahama and water surge in Bimini, but in general the damage was concentrated in the southern part of the Lucayan Archipelago.

The estimated damage for Inagua tourist infrastructure is $\$ 66,805$, mostly to roofs and ceilings. The water surge also damaged the seawall of a guesthouse that caters to sport fishing, estimated at $\$ 15,000$. This property also owned several onshore fishing boats which were moved inland, and no effects were reported. There was damage to a bar and a public gathering space. The situation was similar in Acklins with the estimate at $\$ 11,989$. The tourism in these two islands is fairly small. The main economic activity in Inagua is salt production and in Acklins is fisheries.

The estimated damage for Ragged Island is almost \$0.4 million, all in Duncan Town. Although it is a fishing community, there were three guesthouses that mostly serve anglers. These locations were severely affected, one of them destroyed. The majority of the effects was to common areas for nearly $\$ 0.2$ million and rooms were over \$0.1 million. There was also significant damage to the roof and ceilings and to the landscape. Two of the three fishing businesses are likely to be rebuilt, however there are doubts about the recovery of the third business after the effects of Irma.

The islands of Bimini and Grand Bahama, although not directly hit by the storm, sustained effects due to tornados and water surge. In Bimini the estimated damage in the tourism infrastructure is $\$ 72,197$. This is mostly related to the effects to rooms due to water intrusion. There was sea erosion and seawall damage in Luna Beach estimated at \$20,000, and also in some of the guesthouses. There was extensive damage to the piers of several of the hotels and guesthouses, and to some marinas. This information is included in the infrastructure section of this report.

The damage in Grand Bahama was far smaller than with Hurricane Matthew, and some property damage could be dated back to Matthew. Nevertheless, there was roof damage in some of the buildings of Port Lucaya Market Place 
and the Pelican Hotel, estimated at \$25,361. There were some small lodges affected in Andros, where the damage is estimated to be $\$ 47,000$.

The total damage to the tourism sector is nearly \$0.6 million. This figure is small compared to Matthew and other previous storms. Irma was a very powerful and destructive storm; however, the damage is relatively small because there was little touristic property exposed to the direct effects. This does not imply the damage to touristic business is not devastating for smaller communities like Ragged Island. The damage is small in relation to the whole Bahamian economy, but as is often the case, very large for certain small communities.

Table 52 - Summary of Damage in the Tourism Sector

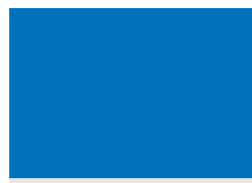

Roof \& ceiling

Rooms

Common areas

Landscaping

Equipment

Others

Total

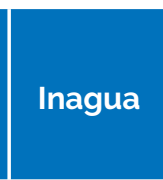

48,146

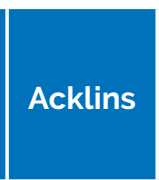

7,803

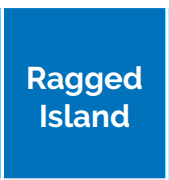

62,558

126,750

157,803

$827 \quad 11,948$

0

6.720

15,000

$\$ 66,805$

3,000

5,000

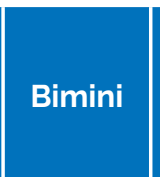

21,004

9,750

845

5.597

0

35,000

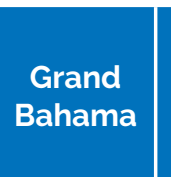

25,361

0

0

0

01000

o 160,052

21,986

O 42,000

48,720

0

\section{$\$ 11,988$}

$\$ 370,779$

\begin{tabular}{l|l}
$\$ 25361$ & $\$ 47,000$
\end{tabular}

$\$ 594,131$

Source: Assessment team.

\section{Losses}

Even if Irma did not directly impact the main islands of The Bahamas, the disruption in the tourism sector was significant throughout. The hurricane was a powerful storm, and spent a lot of time in the ocean before it made landfall in the Leeward Islands. Irma got massive news coverage for good reason, and started to disrupt the flow of tourists a few days before preparation for the storm started.

To estimate losses the assessment team employed official figures provided by the Ministry of Tourism up to August 2017, and other information gathered during the assessment team's fieldwork. We made some plausible assumptions about the flow of tourists and their behavior to forecast the monthly income baseline. We then made calculated assumptions on how the recovery will take place to calculate the losses. In this case there were no significant losses in room capacity or infrastructure related to the tourism sector. Leaving aside Bimini and Ragged Island, there were no losses in room capacity or related infrastructure. The losses are related more with demand effects, and how the disruption affects air and sea traffic to and from The Bahamas. There are also a few more permanent effects to take into consideration. The first one is that Irma caused important damage in Florida, the main origin of tourism in The Bahamas. The second one is related to the requisition of the Grand Celebration Cruise from FEMA. This cruise is responsible at times for around 30 per cent of the cruise ship visitors that arrive at Grand Bahama. 
Figure 11 - Income and Losses

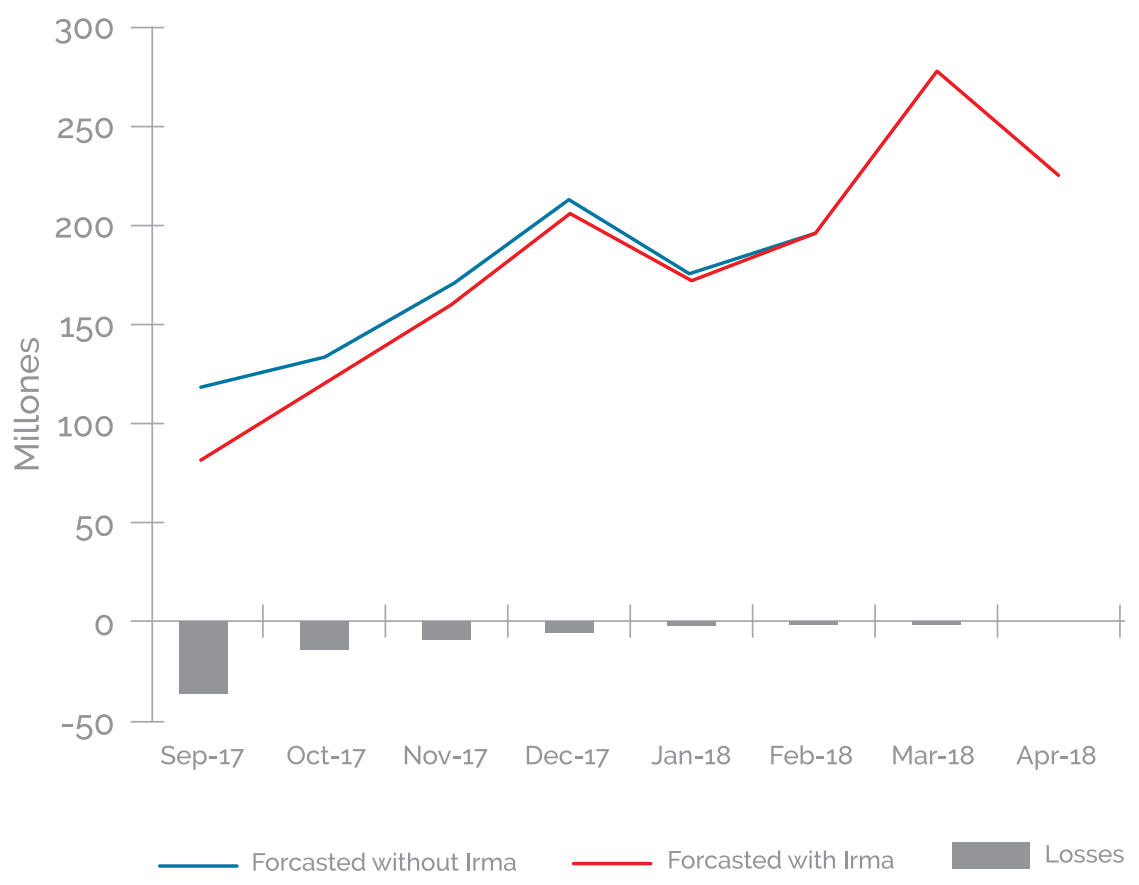

Source: Assessment team.

The monthly forecasted tourism expenditure is displayed in Figure 9. The first scenario is the baseline scenario forecasted without Irma, the second one with Irma. The losses are the difference between the two. A full recovery is predicted by April, but it is important to consider that a full recovery does not include the reopening of two major resorts in Grand Bahama that did not come back after Matthew, just a recovery to the situation prior to Irma.

Total losses in The Bahamas from Hurricane Irma is estimated just short of $\$ 68$ million. Like Matthew, Irma struck in low season, which brought fewer losses. More than half of the losses occurred in September (over \$36 million); about 43 per cent occur in the last quarter. The disruptive effects of Irma for 2018 are almost negligible, even for Grand Bahama, which will take longer to recover than New Providence and the Out Islands.

Table 53 presents the total losses by type of visitor for New Providence, Grand Bahama and Out Islands. The majority of the losses are due to the forecasted decline in stopover visitors (\$52 million). Around 77 per cent of the total losses are of this nature, while the remaining loses are from cruise and day visitors.

Table 53 - Total Losses in the Tourism Sector by Type of Visitor

\begin{tabular}{|l|r|r|r|r|}
\hline & Stopover & \multicolumn{1}{|c|}{ Cruise } & \multicolumn{1}{c|}{ Day } & \multicolumn{1}{c|}{ Total } \\
\hline New Providence & $36,210,848$ & $10,619,964$ & 47,199 & $\$ 46,878,011$ \\
\hline Grand Bahama & $3,714,497$ & $4,084,555$ & 25,176 & $\$ 7,824,228$ \\
\hline Out Islands & $12,521,430$ & 675,899 & 28,345 & $\$ 13,225,674$ \\
\hline The Bahamas & $52,446,775$ & $15,380,417$ & 100,720 & $\$ 67,927,912$ \\
\hline
\end{tabular}

Source: Assessment team 
With Matthew the next highest expenditure to incur major losses was food and drinks. With Irma the second highest was shopping with close to \$12 million. This is due to the disruption of tourism regarding cruise ship visitors is greater than any other visitor, and they tend to spend the most money on this activity. The third expenditure is food and drinks with losses of $\$ 9.4$ million, followed by activities with $\$ 7.9$ million. The losses in the casinos amount to \$4.4 million and in transportation \$3.3 million. The remaining losses for other expenses are just shy of $\$ 1$ million.

Table 54 - Total Losses in Tourism by Type of Expenditure

\begin{tabular}{|l|r|r|r|r|}
\hline & Stopover & Cruise & Day & \multicolumn{1}{|c|}{ Total } \\
\hline Accommodation & $30,326,159$ & 0 & 0 & $30,326,159$ \\
\hline Food and drinks & $7,558,544$ & $1,902,553$ & 12,376 & $9,473,473$ \\
\hline Activities & $3,226,048$ & $4,634,766$ & 31,483 & $7,892,297$ \\
\hline Shopping & $4,144,706$ & $7,374,688$ & 47,806 & $11,567,199$ \\
\hline Transportation & $2,475,223$ & 825,923 & 5,326 & $3,306,472$ \\
\hline Casino & $3,774,487$ & 620,859 & 2,823 & $4,398,168$ \\
\hline Other & 941,609 & 21,629 & 907 & 964,145 \\
\hline Total & $\mathbf{\$ 5 2 , 4 4 6 , 7 7 5}$ & $\mathbf{\$ 1 5 , 3 8 0 , 4 1 8}$ & $\mathbf{\$ 1 0 0 , 7 2 1}$ & $\mathbf{\$ 6 7 , 9 2 7 , 9 1 3}$ \\
\hline
\end{tabular}

Source: Assessment team.

Losses by type of expenditure are presented in Table 54. The total losses for accommodations are over \$30 million. exclusively from stopover visitors. Accommodation is the biggest expense for tourists; concordantly they represent around 45 per cent of the losses. However, these losses are fundamentally due to the disruption in the flow of tourists, they do not reflect any significant losses in room capacity. The desegregation for type of expenditure and type of visitor is presented in Table 55.

The tourism infrastructure of New Providence remained intact and was not affected by Irma; nevertheless, this is where the losses are concentrated. This is because Paradise Island and Nassau are the major destinations for tourism in The Bahamas. New Providence represents 69\% of the total losses (\$46.9 mil(ion). Accommodation is the biggest expenditure affected with \$20.6 million. Shopping showed losses of nearly $\$ 8$ million, followed by food and drinks with foregone revenue of $\$ 6.8$ million. The losses from activities and tourism operators will be $\$ 4.8$ million. Losses to the casinos were estimated to be close to \$4.3 million and in transportation \$1.2 million. Finally, there were additional losses of \$0.6 million. 
Table 55 - New Providence Losses by Type of Visitor

\begin{tabular}{|l|r|r|r|r|}
\hline & Stopover & Cruise & Day & \multicolumn{1}{|c|}{ Total } \\
\hline Accommodation & $20,553,277$ & 0 & 0 & $20,553,277$ \\
\hline Meals and Drinks & $5,446,112$ & $1,338,115$ & 5,947 & $6,790,174$ \\
\hline Activities & $1,879,343$ & $2,867,390$ & 12,744 & $4,759,477$ \\
\hline Shopping & $2,694,087$ & $5,235,642$ & 23,269 & $7,952,998$ \\
\hline Transportation & $1,376,012$ & 594,718 & 2,643 & $1,973,373$ \\
\hline Casino & $3,664,538$ & 584,098 & 2,596 & $4,251,232$ \\
\hline Other & 597,479 & 0 & 0 & 597,479 \\
\hline Total & $\mathbf{\$ 3 6 , 2 1 0 , 8 4 8}$ & $\mathbf{\$ 1 0 , 6 1 9 , 9 6 3}$ & $\mathbf{\$ 4 7 , 1 9 9}$ & $\mathbf{\$ 4 6 , 8 7 8 , 0 1 0}$ \\
\hline
\end{tabular}

Source: Assessment team

Although Irma did not hit Grand Bahama directly, there are significant losses regarding the disruption of visitors, and also the requisition of the Grand Celebration by FEMA until late December. It is important to emphasize that the island did not fully recover from Matthew- two of the major resorts of the island are still out of business.

Table 56 - Grand Bahama Losses by Type of Visitor

\begin{tabular}{|l|r|r|r|r|}
\hline & Stopover & Cruise & Day & \multicolumn{1}{|c|}{ Total } \\
\hline Accommodation & $1,882,879$ & 0 & 0 & $1,882,879$ \\
\hline Food and drinks & 648,923 & 481,977 & 2,971 & $1,133,871$ \\
\hline Activities & 326,133 & $1,548,046$ & 9,542 & $1,883,721$ \\
\hline Shopping & 454,654 & $1,821,711$ & 11,228 & $2,287,594$ \\
\hline Transportation & 196,497 & 196,059 & 1,208 & 393,764 \\
\hline Casino & 109,949 & 36,761 & 227 & 146,937 \\
\hline Other & 95,463 & 0 & 0 & 95,463 \\
\hline Total & $\mathbf{\$ 3 , 7 1 4 , 4 9 8}$ & $\mathbf{\$ 4 , 0 8 4 , 5 5 4}$ & $\mathbf{\$ 2 5 , 1 7 6}$ & $\mathbf{\$ 7 , 8 2 4 , 2 2 8}$ \\
\hline
\end{tabular}

Source: Assessment team.

The highest figured losses go to shopping with \$2.3 million. Grand Bahama will lose \$1in accommodation, though estimated losses in accommodations due to Matthew were 8.3 times bigger. The baseline scenario for Irma does not include the Grand Lucayan Resort and Memories Grand Bahama room capacities. Activities connected with tourism will suffer losses of \$1.9 million, while losses to the restaurant business will be $\$ 1.1$ million. Taxi drivers and the rest of transportation will experience losses of \$0.4 million. Casino and other expenses will forego over \$0.2 million.

The southern portion of the Out Islands were directly impacted by Irma but the losses in this group come mostly from the disruption in the flow of tourist. More than half of the forgone revenue is in accommodation with $\$ 7.9$ million. Food and drinks is the second highest loss in expenditure with \$1.5 million and 
followed by shopping with over $\$ 1.3$ million and $\$ 1.2$ million in activities. The transportation related to tourism will experience losses of almost \$1 million and the remaining estimate of \$0.3 million in other losses.

Table 57 - Out Islands losses by Type of Visitor

\begin{tabular}{|l|r|r|r|r|}
\hline & Stopover & Cruise & Day & \multicolumn{1}{|c|}{ Total } \\
\hline Accommodation & $7,890,003$ & 0 & 0 & $7,890,003$ \\
\hline Food and Drinks & $1,463,510$ & 82,460 & 3,458 & $1,549,428$ \\
\hline Activities & $1,020,572$ & 219,329 & 9,198 & $1,249,099$ \\
\hline Shopping & 995,964 & 317,334 & 13,308 & $1,326,606$ \\
\hline Transportation & 902,714 & 35,147 & 1,474 & 939,334 \\
\hline Casino & 0 & 0 & 0 & 0 \\
\hline Other & 248,667 & 21,629 & 907 & 271,203 \\
\hline Total & $\mathbf{\$ 1 2 , 5 2 1 , 4 3 0}$ & $\mathbf{\$ 6 7 5 , 8 9 9}$ & $\mathbf{\$ 2 8 , 3 4 5}$ & $\mathbf{\$ 1 3 , 2 2 5 , 6 7 4}$ \\
\hline
\end{tabular}

Source: Assessment team.

\section{Additional Costs}

The Additional costs add up to over \$0.1 million. Of those, \$37,223 is associated with debris removal, and $\$ 100,000$ dollars was invested by the Grand Bahama Island Tourism Board to promote the island to counteract the negative effects of Irma on the demand for tourism.

Table 58 - Summary of Additional Costs in the Tourism Sector

\begin{tabular}{|l|r|}
\hline \multicolumn{1}{|c|}{ Island } & \multicolumn{1}{|c|}{ Cost } \\
\hline Inagua & 1,036 \\
\hline Acklins & 449 \\
\hline Ragged & 32,360 \\
\hline Bimini & 1,860 \\
\hline Grand Bahama & 101,268 \\
\hline Andros & 250 \\
\hline Total & $\mathbf{\$ 1 3 7 , 2 2 3}$ \\
\hline
\end{tabular}

Source: Assessment team. 


\section{Introduction}

Irma caused extensive damage in the southern islands of the Lucayan Archipelago. The effects were particularly significant in Duncan Town, Matthew Town, and Salina Point. For some of these communities the main activity is fishing. Even if Irma did not cause great damage, it affected the most important fishing area of The Bahamas, the Great Bahama Bank.

The fisheries sector suffered \$1 million in damage and \$12.9 million in losses. The majority of the damage and losses were concentrated in New Providence and Spanish Wells, but in relative terms, the impact of Irma was stronger in small communities like Duncan Town and Salina Point.

The information for this section comes from the fieldwork observation and interviews, from official institutions like the Ministry of Agriculture and Marine Resources, The Central Bank of Bahamas and The Department of Statistics of The Government of Bahamas, as well as fieldwork and interviews with stakeholders.

\section{Baseline Information}

Fishing is an important activity in The Bahamas. It is a source of employment for many Bahamians, one of their major exports and a fundamental source of food for the local population and the many tourists that visit the archipelago.

The main catch is spiny lobster, according to the Fisheries and Aquaculture department in The Bahamas: A Review by The Food and Agriculture Organization from the United Nations, in 2015 total catch was 6,526 tonnes. A total of 4,056 tonnes of conch were also landed in 2015. The major finfish are grouper and snapper. A total of 262 tonnes of various groupers were landed during 2014 and around 600 tonnes of snapper. In 2015 there was a catch of a73 tonnes of stone crab. In addition to this there is some small pelagic fishing and sponge collection. The commercial fisheries supply 31 kilograms per capita per year and employs around 9,300 full-time. There are about 4,000 vessels dedicated to fishing.

Fish products represent 35 per cent of total exports during 2016. From the \$202 million exported, \$70.9 million were fish, crustaceans, molluscs and other aquatic invertebrates. Two items are responsible for the majority of these exports. First, frozen spiny lobster tails with \$34.3 million. The two main destinations for these products are USA ( $\$ 17.3$ million) and France ( $\$ 15.7$ million). Second, frozen conch with \$33.8 million. Again, the two major destinies are USA with \$21.6 million and France with \$11.3 million.

The total value of fisheries in a year for The Bahamas is about $\$ 157$ million. The major catch is by far spiny lobster with $\$ 129.4$ million (82.5 per cent). Conch is the second catch with a value of $\$ 19.3$ million (12.3 per cent). The landed value for snapper is \$3.8 million and for grouper species \$1.7 million. Finally, the catch for stone crab is \$2.8 million. 


\section{Damage}

This activity is particularly vulnerable because the infrastructure and equipment is either in the water or in proximity to it. For this section we only considered the damage in commercial fishing vessels, fishing gear and the rest of the equipment to prepare or preserve the catch. The fishing port of Duncan Town in Ragged Island and a ramp in Matthew Town in Inagua were affected, and there was severe structural damage in the buildings in the fishing port of Duncan Town. That particular damage is included in the infrastructure sector and will not be discussed in this section. Also, the damage for sports fishing are included in the tourism sector and also will not be discussed in this section.

Most of the damage to the fishing sector was concentrated in fishing gear. This includes traps, casitas (condos), and fish pots. Some of this gear was inland but the majority of the effects happened to gear left in the water. The estimated total damage in fishing gear is \$974,000. Around 16,520 traps and 2,341 casitas were lost; additionally, over 500 fish pots were also lost. The damage to equipment is related to the freezers destroyed in the Duncan Town fishing facility. In total the damage in this equipment is $\$ 2,800$.

Table 59 - Summary of Damage in the Fisheries Sector

\begin{tabular}{|l|r|}
\hline Vessels & 104,000 \\
\hline Fishing gear & 974,780 \\
\hline Equipment & 2,800 \\
\hline Total & $\mathbf{\$ 1 , 0 8 1 , 5 8 0}$ \\
\hline
\end{tabular}

Source: Assessment team.

Table 59 displays the summary of the damage in fisheries. The total estimate is just over \$1 million. The damage in vessels was relatively small, considering the large fleet of commercial vessels in the country. Only six vessels were reported partially damaged or lost for a total of \$0.1 million. Two fishing boats were reported lost in Salina point in Acklins for a combined value of $\$ 40,000$. Three boats were lost in Duncan Town for a total value of \$60,000; also, there was a vessel with \$4,000 worth in damage in South Andros.

The estimated damage by island is presented in Table 60. The most affected Island is New Providence with close to \$0.5 million. This is due to the scale of operation; the losses for New Providence are exclusively related to the fishing gear. Similarly, the rest of the islands of the assessment had damage of $\$ 308,535$. A big portion of the damage is related to the fleet of Spanish Wells. Once again, the scale of the operation plays a role as is the case for New Providence. The damage for Grand Bahama ( $\$ 0.2$ million) is small related to the sizes of their operations. This is not the case for Duncan Town where the total damage is $\$ 76,300$ but very significant and extensive. This is also the case for Salina Point in Acklins with damage estimated at \$50,800. 
Table 60 - Damage by Island

\begin{tabular}{|l|r|}
\hline \multicolumn{1}{|c|}{ Island } & \multicolumn{1}{|c|}{ Amount } \\
\hline Inagua & 0 \\
\hline Acklins & 50,800 \\
\hline Ragged Island & 76,300 \\
\hline Bimini & 0 \\
\hline Grand Bahama & 171,945 \\
\hline New Providence & 474,000 \\
\hline Rest & 308,535 \\
\hline Total & $\mathbf{\$ 1 , 0 8 1 , 5 8 0}$ \\
\hline
\end{tabular}

Source: Assessment team.

\section{Losses}

The disruption in fishing activity was significant. It is important to recall that lobster fishing season ranges from August to March, with the most productive months being August and September. Fishermen had dedicated time prior to the arrival of Irma to prepare for the event. This includes securing the vessels and fishing gear. These were also considered losses as they were otherwise fishing days. After the storm, a lot of the effort was put in cleaning and recovering, as wells as assessing the conditions of the fishing gear and vessels. In addition to this, water conditions we not conducive to fishing for several days after the storm. Therefore, we assume that the landed catch was halted for several days before and after the storm and the landing was severely reduced several weeks after the storm, also due to the loss of fishing gear.

Table 61 - Total Losses by Catch

\begin{tabular}{|l|r|}
\hline \multicolumn{1}{|c|}{ Catch } & \multicolumn{1}{|c|}{ Losses } \\
\hline Lobster & $11,330,052$ \\
\hline Conch & $1,124,730$ \\
\hline Grouper & 54,721 \\
\hline Other Groupers & 42,149 \\
\hline Snapper & 221,840 \\
\hline Stone Crab & 163,333 \\
\hline Total & $\mathbf{\$ 1 2 , 9 3 6 , 8 2 4}$ \\
\hline
\end{tabular}

Source: Assessment team 
Under these assumptions the total losses were \$12.9 million. The losses per catch are presented in Table 61. Spiny lobster represents 87.6 per cent of the total losses with $\$ 11.3$ million followed by conch with \$1.1 million. The rest of the lost catch totals $\$ 0.5$ million. Like the case of the damage, the losses are very different in relative terms. As an example, in Duncan Town, which suffered significant damage in housing and other infrastructure, a great portion of the fisherman had to spend a lot of time out of the water in the reconstruction effort. For the community this means that the fishing losses will extend for longer periods than weeks immediately after Irma. This is particularly relevant for communities like Duncan Town and Saline Point whose main economic activity is fishing.

The majority of the losses were in fishing gear. The damage in vessels were small as a fraction of the total fleet. This was due to the path of Irma as well as the preparation done in displacing the vessels and securing them. It is hard to think that in the event of a storm the casitas will all be secured inland, but all the traps should be brought in. The possibility of fixing the casitas to the sea ground should be evaluated, at least for a fraction of them. 
MACROECONOMIC IMPACT 


\section{Assessment of the lmpact of Hurricane} Irma on the Family lslands in The Bahamas

\section{Introduction}

The cumulative effects of successive hurricanes have affected The Bahamas. This alongside continued weakness in major sectors, including tourism and financial services has led to negative average growth of -1.5 per cent in the last two years. Nevertheless, there was a weak recovery in 2016, with growth of 0.2 per cent, buoyed by an increase in high-spending stopover visitors.

\section{Performance of the economy during the first half of 2017 before Hurricane Irma}

The economy was already facing several headwinds before it was impacted by Hurricane Irma. Growth was dampened by the delayed opening of the Baha Mar Resort, which partly contributed to a decline in high-spending stopover visitor arrivals. Arrivals were also affected by loss of hotel capacity in Grand Bahama, owing to Hurricane Joaquin in 2016. Total visitor arrivals contracted by 2.0 per cent to 3.27 million in the first half of 2017. This stemmed from a 6.0 per cent fall in air arrivals to 735,221, indicating a significant decline in stopover arrivals. Sea arrivals fell by 0.7 per cent to 2.54 million.

Construction activity remained subdued during the first half of 2017. Nevertheless, some impetus was provided in the first quarter by work on the completion of Baha Mar Resort. Private sector investment in the sector, however, remains weak. Residential construction activity fell in both the first and second quarters. Indeed, total mortgage disbursements for new construction fell by \$12.8 in the first of 2017.

The off shore financial services sector was expected to remain buoyant following modest growth in 2016, owing to ongoing consolidation in the sector. The Bahamas will continue to market its offerings in Latin America and other non-traditional markets to shore up business.

The rate of inflation increased to around one per cent year-on-year to August from 0.15 per cent for the similar period of 2016. The uptick reflected higher prices of housing, water, gas and electricity and other fuels, due to the increase in international fuel prices. Impetus also came from increased costs of education services.

\section{The Fiscal Situation}

The fiscal situation remains a major concern in The Bahamas. Public debt has more than doubled since the global crisis, driven in part by stimulus program to boost activity after the crisis. The past government made a commitment to undertake fiscal consolidation to bring down the debt to sustainable levels, however, despite the bolstering of revenues by the VAT consolidation has not taken 
hold. Efforts to reduce fiscal deficits and debt were compromised by growth in spending on rehabilitation and reconstruction after Hurricanes Joaquin and Matthew in 2015 and 2016. However, this was aggravated by slippages in other areas, including some aspects of government consumption.

Undoubtedly, Hurricane Irma will lead to increased spending on relief and reconstruction in the affected islands. However, the hope is that improved economic activity, bolstered by improved growth in the US and the opening of the Baha Mar would boost revenues to partly offset higher spending. The government has committed to fiscal consolidation. Planned measures include the introduction of fiscal responsibility legislation to contain deficit spending and to ensure that ministries and departments identify financing for new unbudgeted spending initiatives. Further, the government plans to review expenditure programs to improve efficiencymeasures will be taken to strengthen tax compliance by reducing evasion.

Preliminary data for the first month (July) of FY2017/18, indicated that the government registered a fiscal surplus of $\$ 9.1$ million, reversing the deficit of $\$ 15.8$ million posted during the similar period of 2016. Fiscal performance was bolstered by a 10.2 per cent ( $\$ 18.0$ million) reduction in total spending, complemented by a 4.2 per cent ( $\$ 6.8$ million) increase in total revenue. The improved position reflected a cut in both capital spending and government consumption, especially transfers and subsidies. Meanwhile, revenues firmed with 5.1 per cent (\$7.6 million) increase in tax proceeds, linked to higher VAT receipts.

\section{Monetary Developments}

The financial sector continued to register growth monetary liabilities, with the broad money supply expanding by 8.4 per cent year-on-year to June. Savings deposits expanded by 13.5 per cent, offsetting a 5.2 per cent decline in time deposits. Demand deposits rose by 21 per cent as investors took advantage of capital market investment opportunities. Domestic credit increased by 5.4 per cent, reflecting an over 29 per cent growth in net credit to the government. Private sector credit contracted by 1.1 per cent, maintaining the weak trend in recent years. Moreover, the bulk of credit continues to flow to the personal sector, rather than the productive sectors, including tourism and agriculture. The net foreign assets of the banking system grew by 5.3 per cent to $\$ 790.5$ million at the end of June 2017, relative to June 2016.

\section{The Balance of Payments}

The balance of payments current account deficit more than doubled in nominal terms to $\$ 863.3$ million. This reflected a sharp (28.4 per cent) decline in the vital services account surplus to $\$ 576.7$ million, underpinned by significant net payments for construction and other services. Construction payments rose in line with outlays for the completion of the Baha Mar Resort. Developments also reflected lower travel receipts that were associated with lower stopover visitor arrivals and spending. Also, the income account deficit increased in line with higher investment income outflows and compensation of employees. 
Meanwhile, the capital and financial account surplus improved significantly. This reflected a sharp reversal of outflows by commercial banks and a spike in other investments. These were reinforced by a more than doubling of FDI inflow to \$39.9 million.

\section{Impact of Hurricane Irma on The Bahamas}

\section{Impact on GDP}

Before commenting on the impact of the hurricane on economic activity, we consider that the base change of the Bahamian national accounts should be mentioned. The Department of Statistics of The Bahamas changed the base year of the National Accounts from 2006 to 2012. In absolute terms, between 2012 and 2016, the GDP of the new base (2012) is higher than the base (2006) by 26.1 per cent in average.

The main differences in the productive structure of The Bahamas between the two bases can be explained by the following reasons:

1. Adoption, in the new national accounts, of the international recommendations proposed by the 2008 SNA (the 2006 version of The Bahamas accounts was based on the 1993 SNA).

2. Among the main differences, it is worth mentioning the treatment of financial intermediation services indirectly measured (FISIM), the calculation of Central Bank production and other aspects related to the treatment of insurance activity, as well as the adoption of the International Standard Industrial Classification (ISIC), which in its revision 4 relocates several services (in the ISIC revision III several services were incorporated within other activities that produce goods, hence the weight charged by the base 2012 for activities such as "Professional, scientific and technical services "and" Administrative and support services").

3. Incorporation of the information obtained from the household income and expenditure survey (2012) and from the surveys of the companies and productive establishments reclassified according to ISIC revision IV.

4. Introduction of better methodological treatments of basic statistical information.

5. Review of the information published by the Central Bank in the Balance of Payments of the country as well as of the tourism expenditure disseminated by the Ministry of Tourism.

6. There are administrative records used in the 2012 reference compilation of national accounts, as is the case of tax information (value addedtax collection system).

7. Incorporation of the macroeconomic impacts of hurricanes (Joaquin in 2015 and Matthew in 2016) in the recently released figures. 
In summary, when comparing the national accounts between both bases for the years reported in the preceding table (2012 and 2016), it is possible to affirm that the differences are due to methodological and statistical elements that make the new national accounts of The Bahamas an information system. The most robust and modern macroeconomic model incorporates the methodological recommendations adopted from the 2008 SNA and which allows a better comparability of its economy with that of other countries.

The "structural effect" (the notorious differences in the weighting of industries in GDP) makes it impossible to compare the macroeconomic impacts of Irma with those caused by the hurricanes of 2015 and 2016 (Joaquin and Matthew, respectively): the structure of the productiveness of the country is different if it is analyzed in the base 2006 or in the base of 2012 .

Before Hurricane Irma, growth of 1.4 per cent was forecasted for 2017, after the disaster, The Bahamas economy would experience a growth of one per cent, which implies that losses and additional costs affected the growth of economic activity by 0.4 per cent of the country in that year. This lower economic activity resulted in the losses of earnings, and wages and salaries, of \$25.4 million and \$18.7 million, respectively.

\section{Impact on infation}

The rate of inflation is expected to increase marginally, owing to shortages in the fisheries and subsistence crop subsector. Also, shortage of skilled construction workers, especially with strong demand, owing to the ongoing work on the Baha Mar Project is expected to lead to higher costs in construction. Nevertheless, inflation will remain low at under two per cent, influenced primarily by US inflation.

\section{Fiscal Impact}

Hurricane Irma will contribute to a higher fiscal deficit in FY2017/18, reflecting government's contribution to the relief, rehabilitation and reconstruction effort in the affected Family Islands. Severe damage to housing in Ragged Island, and to schools, roads, telecommunications and other infrastructure in Acklins, Grand Bahama, Inagua and the other affected islands will necessitate spending on reconstruction. In its first tranche of spending, the government had budgeted $\$ 5.2$ million for relief expenditure. Funding for this allocation was based on the reprioritization of current budgetary allocations. However, given the scale of the damage in the most affected islands, especially Ragged Island and Acklins Island, it is expected that further allocations will be required to facilitate the reconstruction effort.

The rehabilitation and reconstruction effort are therefore expected to lead to a widening of the fiscal deficit by $\$ 44$ million from 1.0 per cent of GDP to 1.4 per cent of GDP (Table 62 and Figure 10). Total revenue is projected to decline by 0.5 per cent, reflecting loss of revenue from tax exemptions for citizens in the affected islands. The government has issued an exigency order permitting duty free ex- 
emptions on certain goods to aid the relief and reconstruction effort in the affected islands. The order also includes the waiver of customs duty and VAT on acquisitions of building materials and supplies by persons impacted by the hurricane.

Total expenditure is projected to expand by $\$ 35$ million to $\$ 2.3$ billion, or 22.2 per cent of GDP in line with growth in both current and capital spending. Current spending is expected to increase by 1.2 per cent, owing to higher outlays on goods and services that is associated with the purchase of equipment, materials and supplies to aid recovery and reconstruction after the hurricane. Spending on staff costs will also increase, as government hires additional workers to undertake cleanup and reconstruction. Transfers and subsidies are also projected to increase, underpinned by subventions to citizens and public utilities to aid in relief and reconstruction.

Capital expenditure is projected to increase by 4.5 per cent (\$11 million) in 2015 to aid in the reconstruction process. The government was already undertaking a number of projects in the islands that were affected by Hurricane Matthew last year. Important among these were the rehabilitation of the Queens Highway in Acklins at a cost of \$16.7 million, the Crooked Island seawall and carriageway rehabilitation estimated at $\$ 6.6$ million, and the construction of a seawall and road rehabilitation in Long Island (\$1.07 million). It is expected that given the desire to contain the growth of debt, the government would seek to reallocate expenditure from some projects and activities wherever feasible to contain growth in capital expenditure. However, additional spending will still be required, especially for the most affected islands. 
Table 62 - Impact of Hurricane Government Fiscal Operations

\begin{tabular}{|c|c|c|c|c|c|c|}
\hline \multicolumn{5}{|c|}{ Revenue and Expenditure of the Central Government } & $\begin{array}{c}\text { Before } \\
\text { Irma } \\
2017\end{array}$ & $\begin{array}{l}\text { After } \\
\text { Irma } \\
2017\end{array}$ \\
\hline Total Revenue & 1354.6 & 1450.8 & 1701.5 & 1929.6 & 2168.0 & 2158.2 \\
\hline Current Revenue & 1354.6 & 1450.8 & 1701.5 & 1929.6 & 2168.0 & 2158.2 \\
\hline Tax revenue & 1215.5 & 1245.5 & 1500.5 & 1676.2 & 1968.0 & 1958.2 \\
\hline Non-tax revenue & 139.0 & 204.8 & 197.7 & 253.2 & 200.0 & 200.0 \\
\hline Capital revenue b/ & 0.0 & 0.0 & 3.1 & 0.1 & 0.0 & 0.0 \\
\hline \multicolumn{7}{|l|}{ of which: } \\
\hline Grants & 0.1 & 0.4 & 0.4 & 0.1 & 0.0 & 0.0 \\
\hline Total expenditure & 1804.3 & 1849.1 & 1991.6 & 2286.3 & 2268.0 & 2302.6 \\
\hline Current expenditure & 1546.0 & 1596.8 & 1711.3 & 2055.0 & 2026.0 & 2049.7 \\
\hline Goods and services & 354.0 & 308.5 & 331.1 & 340.6 & 359.0 & 368.0 \\
\hline Staff costs & 594.0 & 624.1 & 640.2 & 665.3 & 734.0 & 741.3 \\
\hline Transfers & 598.0 & 664.2 & 740.0 & 1049.1 & 933.0 & 940.4 \\
\hline Interest on the debt & 198.0 & 211.8 & 233.4 & 275.0 & 272.0 & 276.1 \\
\hline Domestic & 148.6 & 148.3 & & & & 0.0 \\
\hline External & 57.8 & 77.0 & & & & 0.0 \\
\hline Others & 400.0 & 452.4 & 506.6 & 774.1 & 661.0 & 664.3 \\
\hline Capital expenditure & 258.3 & 252.4 & 280.3 & 231.3 & 242.0 & 252.9 \\
\hline Net lending & 96.4 & 81.7 & 92.0 & -46.4 & -43.0 & -41.3 \\
\hline Primary balance & -251.7 & -145.0 & -123.4 & -81.8 & 172.0 & 131.7 \\
\hline Overall balance & -449.7 & -356.7 & -356.7 & -356.7 & -100.0 & -144.4 \\
\hline
\end{tabular}

Source: Central Bank of The Bahamas and Assessment Team 
Figure 12 - Fiscal balances before and after Hurricane Irma

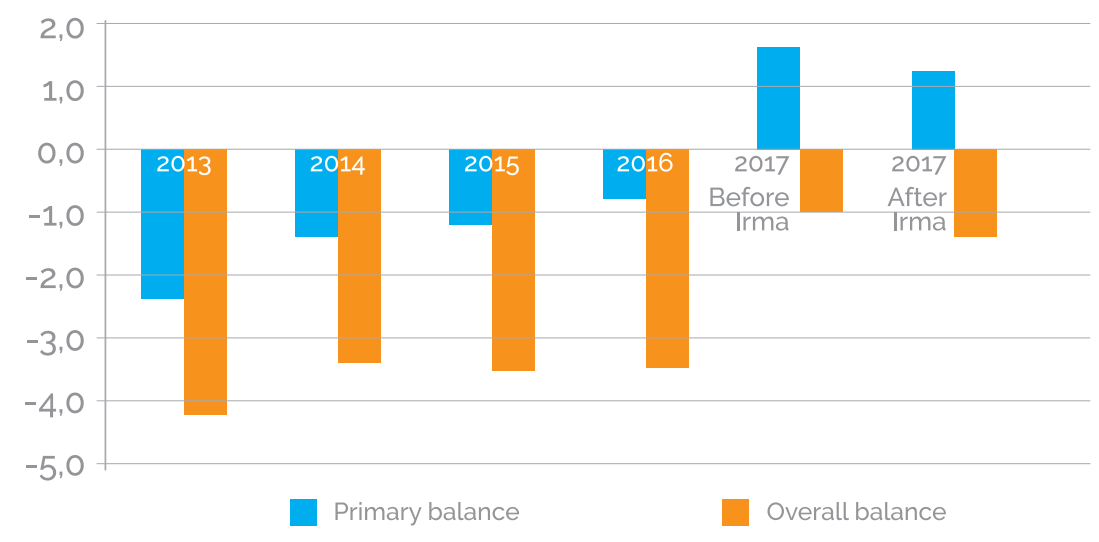

Source: Central Bank of The Bahamas and Assessment Team

\section{Monetary Developments}

The evolution of money and credit is not expected to be much affected by developments after the hurricane. The Bahamas has experienced sluggish growth in domestic credit since the global crisis and this pattern will continue in the short to medium term. Nevertheless, the rebuilding effort in the affected islands is expected to lead to some growth in demand for credit, partly due to refinancing of mortgages by some home owners. However, given their relatively small weight in overall credit demand in The Bahamas, this is not likely to have much impact at the national level.

Overall though, continued high levels of non-performing loans (NPLs) and reduced appetite for risk is expected to constrain bank lending for the rehabilitation process.

\section{The Impact on the Balance of Payments}

The balance of payments current account deficit is expected to widen by roughly \$40.0 million from 14.4 per cent of GDP to 14.7 per cent of GDP in 2017 after Irma. The outcome will be mainly driven by an additional increase in merchandise imports, reflecting higher imports of building materials, equipment and supplies for the reconstruction and relief efforts after the hurricane. Domestic imports are projected to increase by an additional \$20 million to \$3.2 billion, while exports are expected to decline by 2.0 per cent to \$363 million, partly reflecting lower salt exports from Inagua Island and other exports.

The tourism sector did not suffer as much damage or losses as during Hurricane Matthew last year. Nevertheless, some properties on Grand Bahama, Bimini and the other islands were affected. Therefore, travel receipts are estimated to decline marginally by 0.4 per cent to $\$ 2.7$ billion after Irma. Net payments for construction services are projected to increase by around 6.0 per cent, reflecting the hiring of foreign contractors by some hotel and other properties to aid with the repairs and reconstruction. 
The capital and financial account surplus was projected to expand by 1.8 per cent to $\$ 1.7$ billion. Foreign direct investment is expected to increase by around 5 per cent to $\$ 305$ million, partly reflecting increased inflows for reconstruction of some hotel and other tourism properties. Public sector long-term capital is also expected to increase marginally in line with increased borrowing for reconstruction and repairs.

Figure 13 - Balance of payments current account balance before and after Hurricane Irma

Current acount balance

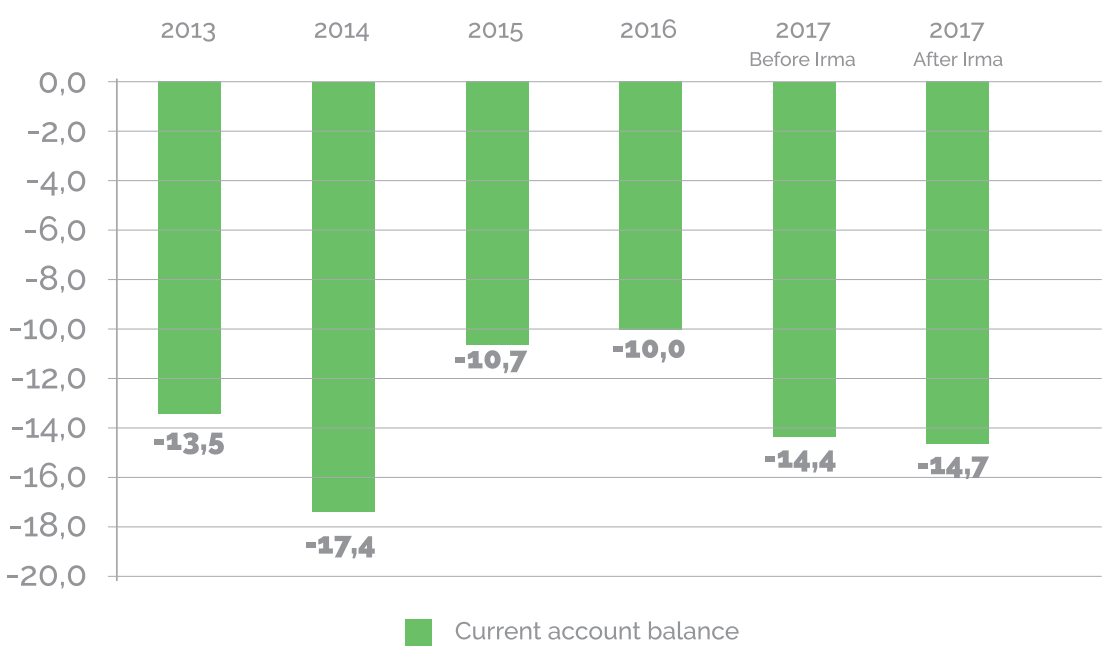

Source: Central Bank of The Bahamas and Assessment Team 
Table 63 - Impact of Hurricane Irma on the Balance of Payments

\begin{tabular}{|c|c|c|c|c|c|c|}
\hline & 2013 & 2014 & 2015 & 2016 & $\begin{array}{l}\text { Before } \\
\text { Irma } \\
2017\end{array}$ & $\begin{array}{l}\text { After } \\
\text { Irma } \\
2017\end{array}$ \\
\hline Current account balance & $-1,439$ & $-1,885$ & $-1,203$ & $-1,126$ & $-1,626$ & -1665.6 \\
\hline Goods (trade balance) & $-2,211$ & $-2,510$ & $-2,434$ & $-2,171$ & $-2,821$ & -2844.3 \\
\hline Domestic exports & 574 & 524 & 372 & 357 & 370 & 362.6 \\
\hline Domestic imports & $-2,763$ & $-3,012$ & $-2,790$ & $-2,517$ & $-3,180$ & -3195.9 \\
\hline Oil & -485 & -488 & -332 & -330 & -383 & -383.0 \\
\hline Capital goods & -657 & -720 & -615 & -615 & -1153 & -1164.5 \\
\hline Other domestic imports & $-1,621$ & $-1,804$ & $-1,843$ & $-1,573$ & -1643 & -1643.0 \\
\hline Other net exports & -22 & -22 & -16 & -11 & -11 & -11.0 \\
\hline Services & 1,046 & 997 & 1,618 & 1,203 & 1,532 & 1519.1 \\
\hline Travel (net) & 2,022 & 2,105 & 2,299 & 2,237 & 2,352 & 2343.2 \\
\hline Travel (credit) & 2,285 & 2,317 & 2,537 & 2,566 & 2693 & 2687.6 \\
\hline Travel (debit) & -263 & -212 & -238 & -329 & -341 & -344.4 \\
\hline Other services Of which: & -976 & $-1,108$ & -681 & $-1,034$ & -820 & -824.1 \\
\hline Construction services (net) & -483 & -645 & -137 & -58 & -143 & -151.6 \\
\hline $\begin{array}{l}\text { Offshore companies local } \\
\text { expenditure (net) }\end{array}$ & 180 & 201 & 166 & 169 & 175 & 175.0 \\
\hline Income and transfers & -274 & -372 & -387 & -158 & -337 & -340.4 \\
\hline Capital and financial account & 1,371 & 1,931 & 1,228 & 1,219 & 1682 & 1713.0 \\
\hline Capital transfers & -10 & -9 & -19 & -14 & -14 & -14.2 \\
\hline Long-term public sector & 144 & 505 & 101 & 219 & 164 & 173.8 \\
\hline Commercial banks' NFA & 62 & -162 & 30 & -306 & -141 & -141.0 \\
\hline Foreign direct investment & 382 & 251 & 76 & 74 & 290 & 304.5 \\
\hline Other private capital $1 /$ & 792 & 1,346 & 1,040 & 1,247 & 1383 & 1389.9 \\
\hline Overall balance & -69 & 46 & 24 & 92 & 56 & 47 \\
\hline
\end{tabular}

Source: Central Bank of The Bahamas and Assessment Team

\section{Macroeconomic Challenges in the Context of the Hurricane}

The Bahamas has been affected by the cumulative impacts of three hurricanes in three years. Moreover, these have come at a time when the economy is confronting macroeconomic imbalance marked by high public debt, low growth and high unemployment. As a result, there is limited fiscal space to undertake the reconstruction effort without contracting more debt and switching expenditure from other activities. 
It is expected that the government will undertake additional borrowing, mainly from the domestic financial sector to finance its contribution to the recovery. This will lead to a short-term increase in public debt, but is necessary to restore the affected, islands, especially Ragged Island, which was severely damaged. Nevertheless, the government needs to maintain its commitment to fiscal consolidation in the medium-term to bring down its debt to a sustainable level.

Climate change and the risks of more intense disasters demand a more robust and stabilizing fiscal policy. The Bahamas, like many other developing, countries have adopted a pro-cyclical fiscal policy stance. This implies that during boom times the government tends to ratchet up spending and is forced to retrench during downturns. Further, as Kaminsky et.al. (2004) have noted in their article "When it rains its pours: procyclical capital flows and macroeconomic policies," the capital flow cycle tends to reinforce the fiscal cycle so that "when it rains it pours'. The Bahamas need to implement strategies to reduce procyclicality so that the government can generate savings during booms to be able to undertake reconstruction after disasters with little or no contracting additional debt.

Priority attention should be given to securing private insurance cover for public properties and to incentivize households to increase their cover. In this regard, fiscal savings from improved fiscal management can be used to buy increased insurance cover under the Caribbean Catastrophic Risk Insurance Facility Segregated Portfolio Company CCRIF (SPC). In addition, government should move expeditiously to implement its planned natural disaster saving fund. This fund should be independently managed with public oversight to prevent conflict of interest and prudent management. Policy should also provide greater incentives for households to purchase insurance cover and to adequately insure their properties. This could be facilitated by opening up the sector to increased competition to drive down the cost of premiums. This would make insurance more affordable to lower income households and small businesses.

Although not the best option, households and small businesses in the affected Family Islands have tended to opt for self-insurance through savings to enable them to recover after disasters. This should be encouraged alongside market insurance. Nevertheless, the capacity to self-insure sufficiently to defray a significant part of the costs of property and other asset damage in a disaster depends on income streams from wages and business profits. In this regard, the governments thrust to facilitate the upgrade and improved competitiveness of domestic small businesses through targeted tax relief and extension services is a good initiative. This should be complemented by training to upgrade the skills and competence of the workforce to enable workers to attain higher paying jobs to grow their earnings. 




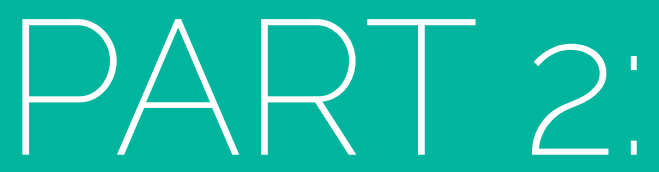

RECOMMENDATIONS 



\section{Recommendations for a Resilient Reconstruction}

\section{Introduction}

Hurricane Irma is the third major ${ }^{14}$ hurricane to strike The Bahamas in the last three years, following Joaquin in 2015 and Matthew in 2016. Some climate science research suggests that one of the expected outcomes of global warming is an increase in the intensity of tropical cyclones. At the same time, the pace at which these storms are affecting The Bahamas certainly appears to have accelerated since the twentieth century. Given these circumstances, it is incumbent upon The Bahamas, as a nation, to develop a comprehensive approach to meeting this threat by integrating disaster risk reduction practices into the social and economic fabric of the country.

The Global Framework on Disaster Risk Reduction (GFDRR) provides a roadmap to achieve this end. It posits five cross-cutting pillars of action that can be applied in every sector - risk identification, risk reduction, preparedness, financial protection, and resilient recovery. Taken together, these pillars provide a framework that can apply not only to the recurring threat of tropical cyclones, but to the country's long-term imperative to mitigate and adapt to the effects of climate change and sea-level rise.

Table 64 - Pillars of Action for Disaster Risk Reduction

\begin{tabular}{|l|l|l|l|l|l|l|l|l|l|l}
\hline Pillar 1: Risk identification & $\begin{array}{l}\text { Improved identification and understanding of disaster risks } \\
\text { through building capacity for assessment and analysis }\end{array}$ \\
\hline Pillar 2: Risk reduction & $\begin{array}{l}\text { Avoided creation of new risks and reduced risk consideration } \\
\text { in policy and investment }\end{array}$ \\
\hline Pillar 3: Preparedness & $\begin{array}{l}\text { Improved capacity to manage crises through developing } \\
\text { forecasting and disaster management capacities }\end{array}$ \\
\hline Pillar 4: Financial protection & $\begin{array}{l}\text { Increased financial resilience of governments, private sector } \\
\text { and households through financial protection strategies }\end{array}$ \\
\hline Pillar 5: Resilient recovery & $\begin{array}{l}\text { Quicker, more resilient recovery through support for } \\
\text { reconstruction planning }\end{array}$ \\
\hline
\end{tabular}

Source: GFDRR, 2012

This section provides the report's recommendations for the resilient reconstruction of those parts of The Bahamas that were affected by Hurricane Irma. It builds upon the five pillars of the GFDRR as an organizational framework, and considers the findings of the Damage and Loss Assessment team during its mission to the affected areas in September 2017. The recommendations provided herein are intended to act as the seeds of ideas that can be further developed to actualize future interventions in the country. These should also be seen as complementary to the recommendations made in the assessments of Hurricanes Matthew and Joaquin. It is important to highlight that, even if the recommendations derive from the analysis of experts during the field visits, each sector should undertake a more in-depth assessment of the risk-factors they 
face, the opportunities for reducing these risks, and means of managing the upfront cost of this risk mitigation. This assessment requires a broad consultative process that should be framed in the context of a progressive national strategy to enhance resilience to natural hazards.

Although the country has started to move forward in this direction, a lot of work remains. There have now been three recent assessments of damage and losses that, together, provide a very full picture of the scope of hurricane risk in The Bahamas. The time has come for the nation to consider where it stands in terms of materializing the recommendations of these documents, and thus to move forward in establishing the resilient society for which they provide a partial blueprint. The IDB and ECLAC stand ready to work in cooperation with The Bahamas to achieve this goal.

\section{Pillar 1: Risk Identification}

This pillar focuses on two main aspects:

i) The assessment of the potential hazards, and

ii)The exposure and vulnerability of communities, assets and services to those hazards.

The potential hazards that affect the broader Caribbean region have been broadly studied. These include hazards that are meteorological, including tropical cyclones, drought and flood, and those of anthropogenic origin, including environmental degradation and oil spills. Geological hazards are also present in the region- while the risk of earthquake in The Bahamas is considered low, tsunami risk remains a factor that could be triggered by an undersea landslide or distant seismic activity.

In addition to these hazards, the long-term influence of global climate change is particularly concerning to small island developing states (SIDS), such as The Bahamas. Although the real impact of climate change on the occurrence and intensity of natural hazards is just beginning to be understood, stakeholders should foresee any variability that could translate in new risks and in an increased vulnerability of the country. In response to this scenario, countries such as The Bahamas should incorporate state-of-the-art planning tools and internationally-recognized good practices to develop strategies that will mitigate the social and economic impacts of disasters in the society and economy, and to implement the construction of development plans at the national and communitarian scales.

Hurricane Irma evidenced once more that natural hazards can damage infrastructure in a way that is felt across multiple sectors. High winds and storm surges caused by a catastrophic event such as a hurricane threaten every asset that lies in its trajectory. Therefore, by addressing infrastructural aspects, complemented with a territorial perspective, stakeholders could significantly reduce the exposure and vulnerability of the population and the assets themselves. 
Most infrastructure assets - including roads, ports, and tourist facilities, etc. - are located close to the shoreline and this condition exacerbates their vulnerability to hurricanes. Infrastructure is of great importance to The Bahamas because it is a cross-cutting sector that influences human well-being and the GDP. In fact, the existence of insufficient or underdeveloped infrastructural assets could represent major obstacles to economic growth and social development in The Bahamas.

Field visits after the last three major hurricanes that struck The Bahamas showed how infrastructure affects the different subsectors. In the case of Hurricane Irma, it caused damage and losses to both public and private assets in islands such as Ragged, Acklins, Great Inagua, Bimini and Grand Bahama. The assessment from the team of specialists evidenced the existence of several new risks in most of the sectors that require the prompt attention from the responsible stakeholder. These risks derive from damage in important assets such as seawalls, airports and roads, and ecosystems such as mangroves.

The sum of the damage exposes the population to new risks in terms of their overall livelihood. For example, injury to the tourism infrastructure and scenic beauty directly lessen the possibility of many employees in the subsector to keep a remunerated and long-term job. The same thing happens in the fisheries subsector where damage in vessels and to port infrastructure impedes fishermen from doing their job normally. Finally, in the case of the education subsector, damage to schools (leaks, roofs, toilets) and related infrastructure (water and sanitation, roads) delayed the reincorporation of students to their regular activities.

Addressing these risks will require stakeholders to have a broad understanding of the territory. By doing so, properly informed Bahamian stakeholders could assure that the design of policy frameworks is aimed at reducing exposure and vulnerability of the national assets to the risks of natural hazards. Therefore, it is imperative for stakeholders in each sector and subsector to count with robust sets of data and information that could serve as a base for the deployment of several analysis tools. In addition, recommendations from previous assessments, such as The Bahamas National Geographic Information Systems Center, the incorporation of Stanford University's NatCaP and the National Hurricane Center's model "Sea, Lake, and Overland Surges from Hurricanes (SLOSH)", should be reconsidered for strengthening and broadening in the future by local stakeholders.

Parallel to the enhancement of data and information gathering, inter-institutional data sharing and capacity building are highly encouraged. The management of disasters is a national effort that requires the articulation of all the stakeholders involved (e.g., government, private sector, civil society). Consequentially, having strong governance frameworks could allow Bahamian governmental entities to improve cooperation between partners (ECLAC and IDB), and to gradually strengthen their capacity to management of disasters. 


\section{Pillar 2: Risk Reduction}

The risk reduction pillar considers the way in which the governance frameworks are targeted to reduce the identified disaster risk. Through this process, national laws, ordinances, and other instruments for long-term planning are adjusted or, in their absence, created. This process also encompasses education and behavioral change of the population in general. In that sense, the reduction of risks can be partially tackled through national policies and strategies, but to address them completely it is necessary to incorporate initiatives at the local and household scales.

In this section, structural and non-structural prevention and mitigation measures to reduce risks in the social, infrastructure and productive sector are considered. In addition, general actions for the formulation of policies and strengthening of institutions are recommended.

In every sector it is recommended to strengthen the relationships between government entities, and cooperation between regional and international agencies is suggested. The exposure and vulnerability to tropical cyclones in The Bahamas requires outstanding first response and follow-up efforts from involved stakeholders. Fortunately, experience has shown that institutions like NEMA constantly improve their understanding of such events and their operations. Nevertheless, there is always room for improvement. Considering the increase on the intensity and frequency of the events of this nature, stakeholders in The Bahamas should aim towards enhancing the work they share with partners across the region. The articulation between the experience gained and the inputs from international cooperation entities are critical to have success when addressing the threats of this nature. Hence, tasks such as reconstruction monitoring and assessments should be incorporated as part of the cooperation portfolio.

\section{Infrastructure: Roads, Airports, Bridges, Docks and Seawalls}

Infrastructure, including roads, airports, bridges, docks and seawalls, are important for The Bahamas since they help move forward socioeconomic development. Unfortunately, the sector absorbs a big portion of the lash during a hurricane. This situation turns more dramatic if we consider that these assets are crucial for the management of disasters since they allow the flow of aid and resources to affected areas.

The first recommendation to reduce risks in the infrastructure sector would be to develop, review and update a Sustainable Master Development Plan in The Bahamas that considers the potential risks to disasters, the integration of the multiple sectors, and its role in the improvement of human well-being. This effort should focus on the different risk factors and should aim at integrating developing plans for water and sewer management, environmental management, infrastructure development, flood mitigation, zoning and land use. It should also consider the repercussions of these potential initiatives in other economic sectors of The Bahamas (e.g., social, productive). The National Development Plan "Vision 2040" could represent a great alternative for decision makers in 
the sector to guide infrastructural improvements to the in order to reduce risks to disasters. Through goals "Modern infrastructure" the Plan contemplates the enhancement of resilience in the infrastructure in The Bahamas.

Bahamian authorities should also see to update and deploy construction codes, standards and guidelines, and enforce their implementation. This is one of the most critical issues that caused severe effects in The Bahamas after Hurricane Irma. Although the country has already issued a building code (2003), there is an apparent disconnection caused by the geographical dispersion of the islands in the archipelago. As a result, the supervision of the compliance to those instruments is difficult. This situation is aggravated after a natural hazard since people tend to expedite their reconstruction which outpaces any supervision effort. Consequently, to address this situation the incorporation of the concept of essential infrastructure is suggested. This type of infrastructure refers to the assets that are critical to the functioning of the society and the economy. Essential infrastructure should be properly designed and build under special considerations to withstand the most common threats. Other important measures in this regard are:

- $\quad$ Revise existing building codes, standards, procedures, and construction manual;

- Develop/upgrade construction manuals to provide contractors and the community in general with practical guidelines and instructions to avoid non-resilient constructions;

- Enhance regional/sectorial supervision and inspection initiatives to monitor the compliance of codes and standards, and. To do so, additional resources should be targeted for this purpose;

- Deploy communitarian educational and training campaigns to inform about resilient reconstruction and disaster reduction in the household.

\section{Productive: Tourism}

Compared to Hurricane Matthew, Irma had no significant impact on the large tourism infrastructure of The Bahamas. Unfortunately, the effects on some small communities and their touristic facilities were considerable. Since most of the tourist facilities in these small villages are houses adapted as pensions or hotels, many were not built according to the respective codes.

It is crucial to ensure that repair and rebuilding efforts are done to the existing codes and standards. The water surge severely damaged properties close to the seashore making it imperative that any new touristic development is done with the proper setbacks from seashore, and if required, complemented with the construction of stilts or seawalls. Additionally, because the hurricane caused damage in the natural landscape, either from the intrusion of saltwater or the direct impact of the wind, replanting initiatives should be deployed. Resilient species of plants and trees should be used and species with superficial roots should be avoided because of their tendency to uproot. Plants and trees 
should be planted in groups since they tend to withstand strong winds better. Finally, the removal of compromised trees should be considered, especially those prone to uprooting (e.g., casuarinas).

\section{Productive: Agriculture and Fisheries}

Like in other sectors, it is crucial that the new agriculture structures are built or reconstructed following proper building codes. It is important that new greenhouses use materials that are more suitable for the weather conditions in The Bahamas. In addition, their design should be done in a more resilient way. This includes moving away from square crystal greenhouses that are particularly vulnerable to wind damage.

In the case of fisheries subsector, the vulnerability of its infrastructure is higher since it is almost exclusively located close to seashores. Hence, any reconstruction should take this into consideration and be built according to the potential risks. In addition, the mangroves should be protected, as they act as natural barrier that contribute reducing the impact of water surge and waves damage. Finally, because a big portion of the fishing gear was lost or damaged during the storm, fisherman should explore the possibility to anchor them securely and more frequently.

\section{Social: Housing}

In the field visits by the assessment team to the southern islands of The Bahamas, it was possible to identify three issues that made dwellings vulnerable to storms:

i) Compliance to the building code;

ii) Flood due to water surge, and;

iii) Design.

Regarding the first issue, full compliance to the current building code is highly encouraged. This is imperative in areas such as the ones visited and in low-income areas across the archipelago. To enforce the compliance to the current building code several measures can be incorporated. Firstly, the creation of a popular builder's handbook is encouraged. The objective of this handbook will be to guide step by step the principles and technical methods required to comply with the building code. This document should target construction workers and specialists, regardless of their educational level. In addition, this handbook should include typical construction details and construction drawings of already calculated projects and should detail the suitable materials to build safe and affordable houses or related infrastructures.

The Handbook should contain explanations to guide the construction process and indicate when permits or approval are required. It should include instructions to ensure safe connections to electrical grids, sewage systems and means for the disposal of solid waste. Secondly, the government should strengthen the audit, inspection and supervision. The Ministry of Works must guarantee that design and construction processes comply with basic standards to ensure the integrity of every structure. In that sense, the lack of building inspection processes 
is particularly relevant in the family islands since their population is isolated and there is limited local engineering expertise. To reach these zones, supervision should be expanded through assignation of additional financial resources.

Lastly, the development of the standards and the revision and update of the current building code should be done. Such initiatives should be complemented with the design and implementation of technical training programs to develop local capabilities in regard to the related codes and standards.

In relation to the second issue, every year containing tropical storms and hurricanes the water surge affects the housing sector, making it imperative to generate a planned zoning system and a "Master Plan" for coastal development that contemplate the housing issues of the archipelago. The Vision 2040 Plan could also represent a great alternative for the housing sector. In fact, the Plan considers housing a cross-cutting topic that permeates several sectors such as the environment, poverty and discrimination. The Vision 2040 document seeks to produce an Integrated Coastal Zone Management Plan (ICZMP) that will guide any housing development near to the coast. In addition, responsible stakeholders should ensure that all exterior elements like water tanks, pumps, generators, gas bottles, and air conditioning units are sufficiently secured and protected against high-speed winds and storm surge. This plan should cover technical, sociological, economic and political aspects because it may imply difficult decisions such as moving villages and prohibiting the inhabitation of certain areas. There are different types of solutions for flooding conditions in endangered low-lying areas, such as coastal zones. The most popular option is the elevation of the dwelling using materials such as wood, concrete columns, or piles, or through pre-engineered solutions like multipoint foundation systems.

Finally, in relation to the third issue, the most common damage in the housing subsector as evident in Hurricane Irma is the loss of shingles. This issue is considered a low-impact damage. Water barriers, such as a sealed roof decks could prevent significant water intrusion in case the pieces of the roof are blown away. These structures also provide additional insulation to make dwellings more energy efficient. An evaluation of the existing roof materials and techniques to better help prevent damage is highly recommended (Table 57).

Table 65 - Materials and techniques to protect shingles

\begin{tabular}{|l|l|l|l|l|l|}
\hline $\begin{array}{l}\text { Type of roof } \\
\text { finish }\end{array}$ & $\begin{array}{l}\text { Asphalt } \\
\text { Shingles }\end{array}$ & Metal & Slate & Tile & $\begin{array}{l}\text { Wood } \\
\text { Shingles }\end{array}$ \\
\hline $\begin{array}{l}\text { Protection to } \\
\text { wind storm }\end{array}$ & Average & Better & Best & Better & Average \\
\hline Aging & Worst & Better & Best & Better & Worst \\
\hline Cost & Lowest & High & Highest & High & High \\
\hline Pros & Most popular & $\begin{array}{l}\text { Attractive } \\
\text { Light weight }\end{array}$ & Last longer & $\begin{array}{l}\text { Popular in } \\
\text { some areas }\end{array}$ & $\begin{array}{l}\text { Attractive } \\
\text { wood }\end{array}$ \\
\hline Cons & $\begin{array}{l}\text { Aging } \\
\text { decrease } \\
\text { protection }\end{array}$ & $\begin{array}{l}\text { Impacts } \\
\text { cause } \\
\text { dimples }\end{array}$ & $\begin{array}{l}\text { Heavy and } \\
\text { expensive }\end{array}$ & $\begin{array}{l}\text { Heavy and } \\
\text { can broken }\end{array}$ & $\begin{array}{l}\text { Some } \\
\text { codes not } \\
\text { compliant }\end{array}$ \\
\hline
\end{tabular}

Source: Central Bank of The Bahamas and Assessment Team 
Damage due to design deficiencies usually occurs in the weakest links in the load path. To prevent this issue, it is recommended to correct the connection by anchoring all the elements from the foundation to roof. Also, to reinforce the foundation-to-wall, wall-to-floor, floor-to-floor and wall-to-roof connections allows dwellings to resist high-wind forces as a unit. In a meeting with stakeholders in The Bahamas it was highlighted that this type of construction is very suitable for the construction of houses because it has proven to be effective to withstand effects of tropical storms. In addition, the houses built with masonry walls, concrete columns and reinforcing steel structure properly connected to the concrete foundation well supported to the solid ground.

As a final recommendation to address the design weaknesses in the housing sector in The Bahamas, the specialists encourage the use of gables taller than 4 feet since they allow reinforcing the framing and bracing the top and bottom of the structures. It is important to clarify that these gables should be designed for specific locations and types of homes.

The use of concrete roofing is also an alternative that should be considered in The Bahamas. The widespread use of concrete roofs proved to be effective in reducing damage to housing and other buildings in Anguilla.

\section{Social: Education}

The infrastructure in the subsector has been severely affected by the increased intensity and occurrence of tropical cyclones. Hence, inspections of school premises should be mandatory and scheduled before hurricane season every year. This will assist in the identification and removal of threats, such as large trees, faulty fences, and over-burdened utility poles near school premises. Equally important is the strict adherence to school maintenance, ensuring the cleaning of drains in and around the school or the reinforcement of faulty doors or windows. When reducing risks to potential hazards, attention should be paid to seemingly minor issues. The effects of Hurricane Irma suggest that a small matter such as a faulty door can develop into a bigger problem if breached by hurricane winds.

The protection of items vulnerable to water damage, such as photocopiers, printers, computers, electric cables and audio-visual equipment, should also be a standard practice leading up to a hurricane. School staff should be provided with a hard copy of a manual illustrating the best practices for protecting equipment, and this information should be shared with them again through electronic means as they prepare for the storm. They should have access to plastic sheeting and duct tape, which can be used to protect equipment from the intrusion of moisture during the storm. If possible, staff should identify a room within the interior of one of the school buildings in which to store this equipment that would offer the most protection from water damage.

\section{Social: Affected Population}

Ragged Island was one of the most affected islands by Hurricane Irma. Among the damaged infrastructure, six official buildings were counted. One of them was intended as a shelter, however, it was destroyed. A comprehensive review and 
evaluation of all buildings used as shelters should be carried out. This should be done in order to identify damage in the buildings and to establish a new list of available shelters. It is also recommended that such evaluations are done rigorously and periodically to ensure the well-being of people of The Bahamas.

There is also an apparent need for a public information campaign concerning the risk of storm surge. During Irma, there were several locations where a "reverse storm surge" occurred, causing water to be drained from shallow areas on the periphery of the storm. Images of this phenomenon were spread via social media, including video of person walking on the dry seabed. Such activity is extremely dangerous, as it is quite possible for the water to return rapidly as the wind shifts during the passage of a storm. Indeed, there was a dry seabed noted at Lowe Sound during Hurricane Matthew, shortly before the town was inundated by ten feet of surge. In future events, officials should be prepared to issue social media-based warnings concerning the danger of storm surge.

\section{Pillar 3: Preparedness}

The preparedness pillar refers to the knowledge and capacities developed by governments, businesses and communities to anticipate, respond, and recover from the effects of a natural hazard. It encompasses the establishment of measures to enable an effective response in case of a disaster. The degree and quality of the preparedness is closely linked to the realization of a sound analysis of risks and to deployment of efficient. Since tropical cyclones are not the only natural hazard that threatens The Bahamas, such measures should be flexible enough to anticipate a wide diversity of disasters.

\section{Social: Affected populations}

The economy of The Bahamas is heavily reliant on that of its neighbor. Florida. However, in the event of a hurricane such as Irma, Florida was itself significantly impacted by the storm, and so it could not be relied upon as a staging area for delivery of relief supplies and personnel. Another regional partner, Houston, Texas, had also recently been impacted by Hurricane Harvey and was also not available for use as a supply hub. Given this experience, it is clear that it would be valuable for Bahamas-based organizations to build a more geographically diverse set of relationships such that, if their traditional supply hubs are affected by future storms, assistance can be readily supplied through, for example, the mid-Atlantic states.

\section{Infrastructure: Telecommunications}

In the telecommunications sector, the recent experiences of Hurricanes Joaquin and Matthew have already been a catalyst for the adoption of improved disaster risk management practices. For example, The Bahamas Telecommunications Company (BTC) has changed its approach to preparation prior to the hurricane season. Previously, the review and renewal of the company's disaster response plan was conducted in May but now the calendar for this activity now encompasses April and May. Thus, the readiness reports can be issued earlier, allowing additional time to remedy any problems that may be discovered as part of the process. It is highly recommended that other tele- 
communications companies incorporate similar practices.

BTC has also begun the process of retrofitting the antennas on its cellular communications towers with additional bracing. Their experience in Hurricane Irma has proven this to be an effective means of reducing the risk that antennas will be blown out of alignment by high winds. The retrofit is simple and only is matter of installing a steel bar across the back of the upper portion of the antennas on a tower. This initiative can be accomplished with relatively little additional investment. In fact, retrofitting an antenna only supposes investing in steel bars, labor and equipment. It is recommended that this practice is adopted as a standard by all Bahamian cellular tower operators.

Image 16- Antennas connected to a tower at one point vs. antennas connected at two points using a bracing bar

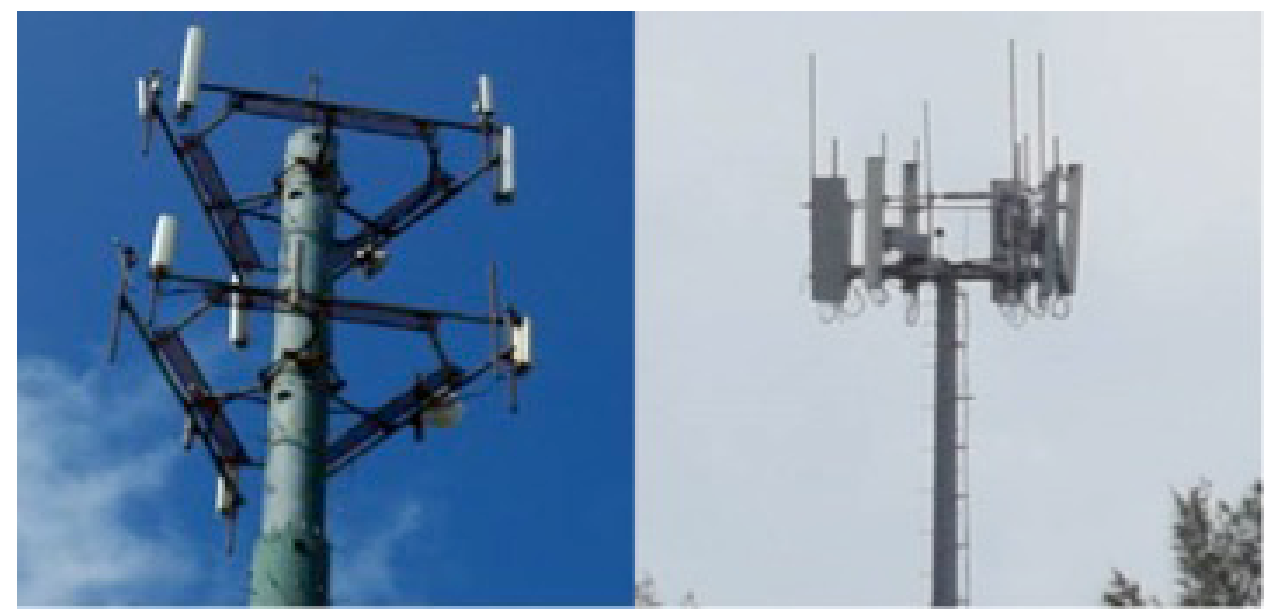

Source: Assessment Team

The telecommunications company, Cable Bahamas, has made their network more resilient by adding "power to the node" systems. This system allows ensuring that distribution nodes are able to remain operational in the event of a loss of commercial power. They have done this by partnering with ALIV, the cellular services company which operates standby generators associated with its cell tower sites. Through this partnership, these generators are now being used to provide backup electricity to nearby Cable Bahamas nodes in the event of a loss of commercial power, supplementing existing battery backup capacity within the nodes.

Loss of commercial power remains the greatest threat to the continuance of operational telecommunications services, particularly mobile services, during and after a disaster. Backup generators at cellular sites are a useful resolution, but the need to refuel generators can cause logistical difficulties that put additional stress on disaster response coordination efforts. There are also concerns about the reliability of generator systems. One the one side, there is some risk that, if unused for a period of time, they may fail to start in the event that they are needed. On the other, if required to run for an extended period following disaster and in the absence of ongoing maintenance, the potential to break down is high. Theft of diesel from cellular sites is also a risk that could affect operational availability. 
With respect to issues of reliability, experiences in other countries have generally shown fuel cells to be a more reliable type of backup power system than the traditional generator sets. However, reliance on available diesel fuel remains a drawback of both fuel cells and generators. This problem could be circumvented through the installation of photovoltaic solar-based backup power systems, in combination with battery storage. Such systems would have the advantage that they could produce power for the cell site - and connected grid - even in times when there is no disaster.

The landline telephone service was also lost in several communities as a result of the destruction of aerial cables. Fixed telephone lines are an important service to consumers, but are vulnerable to such damage and can be expensive to maintain in proportion to the amount of bandwidth that they support. In light of the increasing obsolescence of copper-wire-based landline technology, it is appropriate to consider other options for the delivery of fixed telephone services, including fixed-mobile services and voice-over-IP (VOIP)-based solutions provided via fiber, coaxial cable, or wireless broadband systems. Nevertheless, copper-wire landlines currently support desirable features such as easy integration into 911/999 emergency calling systems, and remain operable during the loss of commercial electrical power. Therefore, means of continuing support for this functionality should remain an important consideration as newer system supplant traditional copper-wire technology.

Finally, there is a need to improve coordination between telecommunications companies and NEMA. While BTC does have a strong connection with the national disaster operations infrastructure as a result of its former status as public entity and as the primary national telecommunications company, other companies do not share this advantage. Broadly speaking, the relationship between telecommunications carriers and national disaster offices is an important one, and it was in fact the topic of a study published by ECLAC in $2017^{15}$, in part based on lessons learned from the experience of Hurricane Joaquin. Both telecommunications personnel and disaster response officials are recommended to review this study as part of a process to work together to build a stronger operating relationship.

\section{Infrastructure: Roads, Airports, Bridges, Docks and Seawalls}

As a result of the missions to The Bahamas the implementation of lessons-learned from previous events such as Mathew and Joaquin as extensively discussed. During the different visits, it was evident that there is a strong coordination and response leadership from NEMA. This institution has done important efforts in integrating members of multiple sectors and institutes in order to provide coherent response to the disaster. Although hurricanes represent a real threat to the countries and its population its nature allows authorities and the population in general to partially anticipate them and gain lead time to plan and execute emergency response actions. Based on our visits and inspection to the affected islands it is recommended for this sector as part of this effort: 
a) Inspect roads, bridges and access to critical areas or buildings such as hospitals, airport, ports and shelters and establish back up plans if required for the evacuation and logistic efforts.

b) Inspect and maintain emergency power generators to address the response effort in critical areas such as airports.

c) Identify and demobilize potential of mobile assets (trucks, planes, boats, construction machinery, trailers, light construction shelters) that can be represent an additional threat to other permanent infrastructure assets during the effects of strong storm wind forces and storm surge.

d) Inspect and review dock facilities, especially light/floating infrastructure (Image 17) to evaluate quick actions and preparedness to mitigate damage.

e) Conduct a proper evacuation of boats and airplanes that can be subject to damage by the path of the storm and can represent a threat to the people and the existing infrastructure.

f) Evaluate critical areas in the populated shoreline and its respective seawall that may represent a risk for the people.

Image 17- Damage to floating docks

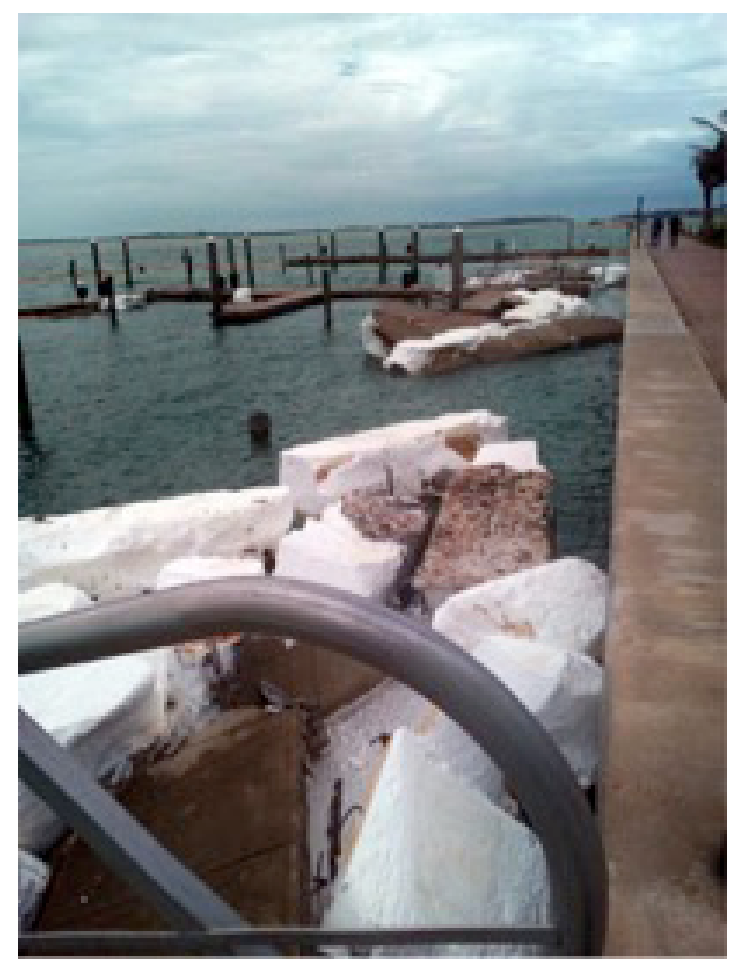

Source: Assessment Team 
In the specific case of floating docks, there was environmental damage in Bimini as a result of the breakup of poly-styrene flotation material that was released into the marine ecosystem when the docks were destroyed by heavy waves. There should be regulation put in place to ensure that this type of design is not used in areas exposed to potential heavy wave action. Additionally, it would be appropriate to redesign this type of dock such that, in the event that it does get destroyed, the floatation material would be released as large, self-contained chunks that could be collected, without the release of tiny plastic pellets that are almost impossible to contain.

\section{Productive: Tourism}

The tourist sector in The Bahamas will face new hurricanes and tropical storms in the future. In that sense, preparedness is fundamental to enhance resilience to future events. Hence, having enough information and data is crucial to develop adequate policies and strategies to better face natural hazards. Efforts in this phase should be done to make sure that information on disaster risk reduction practices is integrated into the training of tourist-sector staff, and that this training is reinforced on an annual basis. For example, maintenance staff need to be aware that it may be necessary to shut down generators during a storm to prevent damage to electrical equipment. Instruction about disaster risks is especially needed by operators of businesses in small villages, as it was noted in field visits that many of these enterprises were not prepared, and that some of the damage they experienced could have been prevented.

Complementarily, touristic facilities should be properly assessed against risk to natural hazards and any improvements planned accordingly. In the case of Hurricane Irma, since most of the boats used for touristic purposes were pulled inshore, some of them were damaged by blowing debris and falling structures. Thus, a means of safeguard these types of boats should be developed, such as the identification of storage locations in areas well-clear of potential hazards.

Finally, it is crucial that the early warning alerts are disseminated on time and every touristic facility starts preparation promptly. This plan should be complemented with efforts in hotels to have documented disaster response plans revised and approved by NEMA.

\section{Productive: Agriculture and Fisheries}

These subsectors share considerable similarities with the touristic sector. One of the most important measures for this subsector is the improvement of early warning system. To do so could translate in the ability to timely move larger vessels away from the storm and to bring inshore the smaller ones. Fishing port and related facilities should count with a plan that includes how to better preserve the facility and were to place the smaller vessels that are pulled inshore.

In the case of the agriculture subsector, the adequate deployment of warning systems could allow for the greenhouses to secure the infrastructure by removing the plastic material and hence permitting the wind to go through. Also, with enough time owners of large cycle crops could take further measures such as pruning to protect the trees and plants. 


\section{Social: Education}

In the Education subsector, hurricane preparedness practices should be standardized across the archipelago. The Ministry of Education should, with previous consultation of the stakeholders, elaborate a hurricane preparation checklist. Should this list already exist, its use should be enforced more eagerly to ensure the deployment of activities such as: premise inspections for vulnerabilities, tree trimming, securing of equipment and school supplies, cleaning of drains, and the battening of windows and doors.

In addition, the yearly Academic Calendar could be adapted to include 'recovery days' to account for the time that is inadvertently lost as a result of the lash of hurricanes and other natural hazards. Preparations could also be made by indicating where the school term can be extended by a few days or a week to account for the teaching days missed by all schools. School closure usually occurs a day or two before a hurricane and schools can remain closed afterward for at least a day or two; even for those schools that have received minimal or no damage. As such, one extra week of school can be added to the Academic Calendar, whenever it is best suited.

Finally, each family island should be equipped with a mist blower and chemicals or access to these items on the island. This initial investment will benefit schools over the long run, as all schools on a given family island can benefit from the use of the mist blower and chemicals to clear school premises of mosquitoes, which are usually ever present after a hurricane as they can begin breeding very quickly with the abundance of settled water. It is not recommended that the mist blower and chemicals be stored on or near any school compound, but instead at some other secure location.

\section{Social: Affected population}

In the days before Hurricane Irma struck The Bahamas, the government coordinated the evacuation of 1,393 individuals from the most threatened islands to Nassau. According to the information gathered by the assessment team during the mission, the evacuation process took place on Wednesday 6 and Thursday 7 of September. The transfer of people who voluntary evacuated was carried out on approximately 24 flights. The authorities affirmed that the evacuation process was timely and orderly. Taking this experience into account, it is advisable to develop an evacuation protocol and necessary legal instruments for this kind of events. This will allow a guide that establishes the action that can be carried out by both the responsible institutions and the population. It is also important to consider that, on this occasion, the evacuation process was voluntary since the Government of The Bahamas does not have a legal instrument to declare compulsory evacuations in case of emergency.

According to information provided by the Ministry of Social Services, 3.519 people were housed in shelters. However, detailed information regarding the number of families, age, sex and whether there are persons with disabilities has not been reported. This type of information is relevant to know where the affected population is, and to determine their most urgent needs. Therefore, it is also recommended 
to develop an adequate protocol for shelter management. In addition, it is advisable to develop a computerized system that allows the entry, maintenance and consultation of a database related to the administration of the shelter.

\section{Pillar 4: Financial Protection}

Risk can be reduced but not eliminated. Thus, it is imperative that countries to protect their fiscal balance and maintain the capacity to respond and recover from emergency. The main objective of this pillar is to create strategies aimed at protecting the different sectors in The Bahamas from the economic impacts of disasters. One of the most common alternatives in this direction is the insurance of the assets and flows of income of the different subsectors in The Bahamas. Nevertheless, depending on the disaster and the coverage rates, in some cases the homeowners and institutions end up absorbing financial shock associated with the need to recover. In general, insurance in the country has two problems: low insurance penetration and underinsurance. Therefore, it is important to consider previously recommended alternatives in the Assessment of Hurricane Joaquin and the Assessment of Hurricane Matthew such as the participation on the elimination of Value Added Tax (VAT) on insurance policies and insuring public assets.

\section{State-contingent debt}

In financing reconstruction efforts related to Hurricane Irma, and in planning for the potential impact of future storms, government officials and lending organizations should consider the use of state-contingent debt. State-contingent debt is used to connect a debtor-nation's obligation to service debt payments with the strength of its broader financial situation. For example, debt payments can be linked to an indicator such as GDP or the number of overnight tourist visits, so that when an economy is doing well, debt is paid back on a relatively rapid schedule. Conversely, if the economy slows down, some relief can be afforded to the country to reduce the fiscal pressure associated with servicing its sovereign debt. State-contingent debt was used by Grenada to refinance its sovereign debts in 2015; in that case, the debt instrument included a "hurricane clause" that was specifically designed to protect the country from disaster risk.

There are two primary ways through which state contingent debt can be linked to disaster risk. The first would be to have a clause in the debt instrument that says, in the event of a disaster that meets certain criteria, the payment schedule on the debt will be delayed by, for example, five years, or the principal will be reduced by a certain percentage. The second model is to have an insurance policy tied to the debt instrument, which covers a country's payments in the event that a disaster has a major impact on GDP. While the addition of an insurance policy can raise the cost of borrowing money, this effect is counterbalanced to an extent because of the reduction in risk to the lender.

The International Monetary Fund (IMF) has been promoting awareness of state-contingent debt for its potential to improve the macroeconomic stability of developing countries and reduce the risk of debt crises to the global economy. A 2017 IMF paper ${ }^{16}$ notes the advantage of state-contingent debt - noting risk-diversifying qualities that would make it appealing to investors - but

16. International Monetary Fund (2017). "State-contingent debt instruments for sovereigns." IMF Policy Paper. May 23. 
suggests that it has a first mover problem; evidence suggests that sovereign states are leery of being among the first to issue state-contingent debt, even as policy makers recognize the potential long-term benefits. The paper cites the concern that, in the short term, markets might charge a premium interest rate because of the novelty of the product. It suggests, however, that as the product becomes more widespread, asset managers will come to recognize state-contingent debt as a tool for diversifying risk, and so markets will develop such that more competitive prices can be offered.

The IMF paper suggests that, to overcome the first mover problem, several countries could group together to issue state-contingent debt at the same time, so that there is sufficient and diverse quantity on the market that it will attract the interest of investors. Caribbean countries, in the wake of the 2017 hurricane season, are prime candidates to become this group of first movers by issuing state-contingent debt instruments to finance their reconstruction. Though reconstruction financing needs are far less for The Bahamas than they are for other countries, such as Antigua and Barbuda and Dominica, by joining with its Caribbean brethren in issuing debt instruments that contain a hurricane clause, Nassau could show leadership and solidarity in the region. This would also benefit the country by helping to establish a market for disaster-linked state-contingent sovereign debt. Should markets develop such that the issuance of such debt can become customary practice, its use could help to protect The Bahamas from the risk of economic fallout resulting from a future hurricane impact. Moreover, as a regional and global financial center, the financial services industry in The Bahamas is well-poised to take on a role in structuring and facilitating the exchange of these securities.

To that end, it is recommended that the Government of The Bahamas and the Inter-American Development Bank reach out to other hurricane-affected countries in the Caribbean, as well as to regional organizations like ECLAC and the Caribbean Catastrophic Insurance Fund, and to global finance institutions, including the IMF, to develop a plan through which state-contingent debt can be used to help finance Caribbean reconstruction and build long-term resilience in the region.

\section{Infrastructure: Power}

An effort to move toward solar power should be one piece of a broader effort to increase sustainability and self-sufficiency, which may be the only way to enable the continued existence of communities located in remote and sparsely populated areas of the country. These communities are a vital part of the Bahamian national identity and for this reason the Government, and of the people of the nation, have long been willing to devote significant financial resources toward subsidizing the physical infrastructure and modern services considered essential to maintaining an acceptable standard of living in the family islands. These subsidies come from both public and private sources. The Government of The Bahamas has paid for an impressive port facility on Ragged Island, and is constructing roads on Acklins - including replacements to sections damaged by Hurricane Joaquin - at a budgeted cost of \$30 million, working out to over $\$ 53,000$ per resident. In another example, Bahamas Power and Light (BPL) provides power to the family islands at a rate of 28 cents per $\mathrm{kWh}$ - the same cost as in Nassau, but generated at significantly higher expense. BTC, Cable Bahamas, and ALIV must 
pay to maintain staff and infrastructure in remote locations as condition of being allowed to sell their services in the population centers of New Providence and Grand Bahama. Ultimately, the cost of providing service to the family islands is passed on to all the country's consumers of telecommunications services.

It should not be assumed that this array of subsidies can itself be sustained, particularly given the vulnerability of the country both to hurricanes and to external financial crises. The risk is most evident in the power sector, where BPL struggles with a high debt burden and continued unprofitability; these have constrained its ability to make capital investments to upgrade outdated, inefficient generation systems in New Providence, let alone in the family islands. The cost of maintaining power systems in the family islands - and of repairing them in the aftermath of hurricanes - has contributed to the company's unfortunate financial situation. Such economic strain can lead to chronic underinvestment in power infrastructure, and risks the possibility that operational and maintenance standards could slip. As Puerto Rico experienced in the wake of Hurricane Maria, financial constraints can so diminish a utility's capacity such that poor system maintenance contributes to catastrophic failure in the event of a natural disaster.

It should therefore be recognized that the financial sustainability of the apparatus required to maintain a country's power grid is nothing less than a matter of national security. To that end, there would be much to be gained by relieving BPL of the expense related to its obligation to provide service in the smallest of the family islands, and to assure that these islands can indeed be self-sufficient in the power sector without the intervention of BPL. A shift toward the use rooftop solar and home battery systems in remote areas would help to accomplish this separation of interests. More broadly, the need to establish a sound financial model underlying the nation's power infrastructure should be an underlying consideration in the process of planning on how best to reconstruct Ragged Island as a proving ground for ideas on bringing sustainability and resilience to family island communities.

\section{Social: Education}

It is recommended for The Ministry of Education to allocate funding to the yearly budget of each school especially for post-disaster recovery. If necessary, schools that have suffered minor damage could access these funds for repairs and replacement of lost materials. Alternatively, a small fund $(<5000)$ could be made available to district offices or the island administration for immediate access. These resources should be targeted to fund schools in need of only minor repairs or leaks. This budget should also be linked to a list of pre-approved contractors that should be responsible of carrying out such minor repair works. Finally, clear guidelines must be set up for the use of these funds so as to prevent mismanagement during the period of disarray that may occur after a hurricane.

\section{Productive: Agriculture and Fisheries}

It is important to encourage the insurance of producers in the agriculture subsector. Insurance could be assigned to crops, especially perennials crops that are hard to protect during a storm. In addition, the insurance of facilities and 
equipment it is highly encouraged. This recommendation also applies for the fishing subsector, particularly in smaller operations. In that sense, the insurance of boats, infrastructure and connected equipment is also recommended. Finally, there is a need to financially protect public infrastructure that serve the fishing industry. To do so, the adequate normative frameworks should be deployed.

\section{Productive: Tourism}

One of the most considerable impacts of hurricanes on the tourism sector is caused by the disturbance in the flow of tourists. Insuring part of theses flows could bring great benefits to businesses in the subsector. According to The Bahamas Insurance Association, the possibility to do so currently exists in The Bahamas. In addition, similarly to other subsectors, the tourism subsector is underinsured. This situation is particularly clear for smaller operators. Thus, there should be an effort to incentivize tourist operators to insure both their properties and their flow of income. To do so, stakeholders in The Bahamas should develop the right incentives and legal mechanisms to push smaller operators access this alternative. Finally, bad publicity adversely affects tourism in The Bahamas. This situation is exacerbated by the increased coverage of hurricanes and natural hazards by the media. Although The Bahamas Ministry of Tourism has assigned more resources to bring up the image of the country, more efforts to promote the country should be deployed. The possibility to establish a fund for this purpose should also be further explored.

\section{Pillar 5: Resilient Recovery}

Although Hurricane Irma represented a traumatic event for the people of The Bahamas, it should be seen as an opportunity to rebuild in a way that the social and economic vulnerability is reduced as much as possible. Stakeholders in The Bahamas should seek to face the yearly hurricane season stronger and to reduce posterior damage and losses in relation to the previous year. This attitude towards natural hazards is of great importance, not only to the hazard that caused the disaster, but to any hazard to which the country or community is exposed. Additionally, resilience to disasters should be properly articulated with the resilience to other phenomena such as climate change. Every building or structure should be resilient by design and should be suitable enough to face the environmental conditions of the region.

As a general recommendation, the use of drones to provide remote aerial view of damaged infrastructure would be and advantageous in providing information to disaster management officials. Because of the vast distances between islands and a potential base station on New Providence, the Ministry of Works officials suggested that long-distance, fixed wing military style drones be used for such purpose. It was further suggested that the country could benefit from private sector capacity with such drones, which could be called upon as they are needed for disaster response. On a smaller scale, it would be possible to establish a network of private-sector drone operators on individual islands, who could provide services at relatively low cost using off-the-shelf drones built for recreational and light-commercial purposes. The difficulty in making use of such a resource would be transmitting photos taken from drones back to the Emer- 
gency Operations Center, potentially in an environment where telecommunications services are unavailable. Thus, it would be useful to ensure that local drone operators have access to satellite-based data transmission systems. This may become financially feasible in the next few years, as multiple commercial entities have plans to launch Low Earth Orbit satellites that should greatly increase available satellite bandwidth.

In addition, there is a need for better training on the use of satellite phones. On Ragged Island, it was reported that, despite the presence of a satellite phone on the island, it could not be used during and after the storm because it was in the hands of persons who had never previously used it.

\section{Infrastructure: Power}

Rebuilding the power infrastructure, especially in places like Ragged Island, the opportunity presents itself to replace generation capacity based on diesel generators with systems based on renewable power sources (i.e., solar and wind). Such a transformation has been endorsed at the highest levels; several days after the storm had passed, Prime Minister Dr. Huber Minnis indicated that "in partnership with the residents of Ragged Island, my government proposes to transform Ragged Island into the first fully green island in the region, utilizing renewable energy and smart technologies from solar energy to sustainable water purification systems ${ }^{17}$." Representatives from Bahamas Power and Light reported that they were initially unclear as to the Prime Minister's intention as to how this mandate would be achieved in the power sector.

Broadly, there are two ways of approaching the task of bringing renewable energy to a community such as Ragged Island: utility scale generation and rooftop solar. Each approach has pros and cons, which should be investigated. Utility-scale generation would entail the deployment of a large field of solar collectors, potentially in combination with wind turbines, which would be used to generate power at a single facility for distribution throughout the community. In 2016, BPL has proposed the installation of utility-scale solar installations for use in places such as Crooked Island, Long Cay, Salina Point, Acklins, though the company has not yet moved forward with the capital expenditure required to construct this infrastructure. Utility-scale solar installations are becoming increasingly common on small islands in the Caribbean. On Caye Caulker in Belize, for example, a field of photovoltaic panels is used to provide electricity to the island's desalination system, and on Anguilla, a \$2.3 million, four-acre solar field was constructed to provide power to 600 households ${ }^{18}$.

Another subtype of utility scale generation that bears consideration are solar roads. Through this technology, hardened photovoltaic cells are utilized as pavers in the construction of roads and sidewalks. This provides a robust paving solution while at the same time enabling the generation of electricity. While solar roads are currently considered to be impractically expensive in mainland applications, the high cost of road-building in a remote island context makes them potentially an economical choice in the family islands. Solar road technology is still progressing through its development stage, so a pilot project would be appropriate to establish an understanding of the practicality of this solution

17. See https://thenassauguardian.com/2017/og/14/pm-makes-pledge-to-ragged-island/

18. This installation was unfortunately destroyed during Hurricane Irma, as the panels were not mounted with lateral bracing sufficient to withstand Category 5 winds. 
for future needs. Though the roads on Ragged Island generally remain in decent shape after the storm and are not in need of replacement, on Acklins there is a section of damaged road near Salina Point that may be a suitable location to test this technology.

The defining characteristic of utility-scale solar is that the power generation capacity is owned and maintained by a single entity in a centralized system. In contrast, independent power producers (IPPs) (e.g., rooftop solar power generation capacity) tend toward a model of individual ownership, with each solar panel installation belonging to the owner of the rooftop on which it sits. By democratizing ownership of the power infrastructure, economic resilience could be created in a place like Ragged Island as the ownership of generation capacity is diffused across the community. Electricity tariffs that had previously been sent off-island could instead provide economic returns that stay within the local economy.

A complication for both rooftop and utility-scale solar power generation schemes is that solar electricity is produced in daylight hours. Hence, some provision must be made to enable electricity use at night. One inefficient solution to this problem would be to simply run a diesel generator during hours of darkness. A greener solution would be to have some type of energy storage infrastructure that can balance out the peaks and valleys of energy production and consumption. Recent developments in manufacturing have made it feasible for battery-based electricity storage to be included as an integral element of solar installations. There are several battery-storage vendors in the market right now, including the automakers Nissan, BMW, and Tesla. This latter one makes a product called Power Wall 2, which is a 245-pound, lithium-ion battery made for installation in homes. It can store $14 \mathrm{kWh}$ of electricity, which is appropriate to the scale of a rooftop solar array. It is also possible to make far larger installations of these cells to support utility-scale installations. Nissan and BMW are bringing similar products to market; both are making use of recycled batteries from each company's respective lines of electric cars.

Battery storage products are another category that, like solar roads, may not be the most economical option on the mainland, but which are well suited to the context of a small island looking to escape high energy costs. Indeed, Tesla is marketing its power wall line for just that context. The company claims to have deployed a $6 \mathrm{mWh}$ installation in American Samoa that, once charged, can power an island of 790 people for three full days. It is also reported that, post-Hurricane Maria, Tesla is in talks with the Government of Puerto Rico to provide its batteries and microgrid expertise to help rebuild the island's destroyed electrical grid. Tesla may be open to providing this type of support to The Bahamas' effort to rebuild Ragged Island, though it might also be worth approaching a company like Nissan, BMW, or one of the other battery storage vendors, to establish a similar partnership.

Such an effort might also consider the introduction of electric vehicles to the island. It is possible to use the battery of an electric vehicle - such as the Nissan Leaf - as a sort of "Power Wall on wheels." In other words, when not being used to drive around the island, a battery-powered car be plugged into the electrical grid and used to store excess power until such a time as there is sufficient demand for it from the grid. Thus, an electric car can fill both a transportation 
role and an energy storage role. Therefore, it may be advantageous to begin the transition from a diesel-powered vehicle fleet on the island to electric, as part of a broader shift to solar. One resource that may be useful in considering this issue is a study that ECLAC published in 2017 which provides a roadmap to describe how the public sector-owned fleet can be transitioned to electric, hybrid, or plug-in hybrid vehicle (Aguilar, Hidalgo, and Peralta, 2017).

Given the context outlined above, one consideration in choosing between rooftop and utility-scale solar should be the relative disaster-resilience of the two options. Indeed, rooftop solar ought to be considered as a more hurricane-resistant option in comparison to utility-scale infrastructure because utility-scale systems are dependent on aerial power transmission and distribution lines, and these have repeatedly proven to be a weak link in this and previous hurricanes ${ }^{19}$. This vulnerability is both because power lines and utility poles are likely to be affected by wind and wind-blown debris, and because it is time-consuming and expensive to dispatch repair crews and material to storm-affected islands. While rooftop solar panels (and utility-scale panels alike) are potentially vulnerable to being blown away in a storm, this problem should be minimized if they are correctly installed and the roofs that they are installed upon are certified to be up to code.

Because telecommunications services in these communities are likely to be transitioning to fully wireless infrastructure, the potential to use roof-top solar and home-based batteries means that it is now a practical option for small islands do away with expensive, unsightly, and vulnerable aerial cable system altogether. While the potential for redundancy and load-balancing may provide some cause to retain aerial network in areas of denser population, certainly in outlying areas and in the very smallest communities, it is recommended to simply assure that every household is equipped with solar panels and a battery backup system, with the understanding that the provision of electrical power to that location will henceforth be the responsibility of the homeowner.

\section{Infrastructure: Roads, Airports, Bridges, Docks and Seawalls}

As highlighted in other subsectors, infrastructure developments should be designed and built according to the approved codes and standards. Local authorities should work towards increasing the enforcement of the relater normative during the design and construction processes. In addition, the selection of building materials should be done more carefully. These materials are very important to support the application of construction codes in The Bahamas and can affect the ability of constructions to withstand hurricanes. Therefore, the use of resistant materials and their standardization are highly encouraged.

As seen in the field visits to the affected areas, roads, especially those close to the shoreline, evidenced an excessive exposure and vulnerability to natural the lash of Hurricane Irma. This is particularly the case on the road from Spring Point Airport to Salina Point. The current situation of the road triggers a risk factor to an important infrastructure asset that interconnects Salina Point with the rest of Acklins Islands. Resilient design such as an elevation is required in these critical points in order to mitigate the impacts of hurricanes and similar natural hazards (Image 18). 
Image 18- Road elevation

The Bahamas

Florida Higway A1A, Flagler Beach

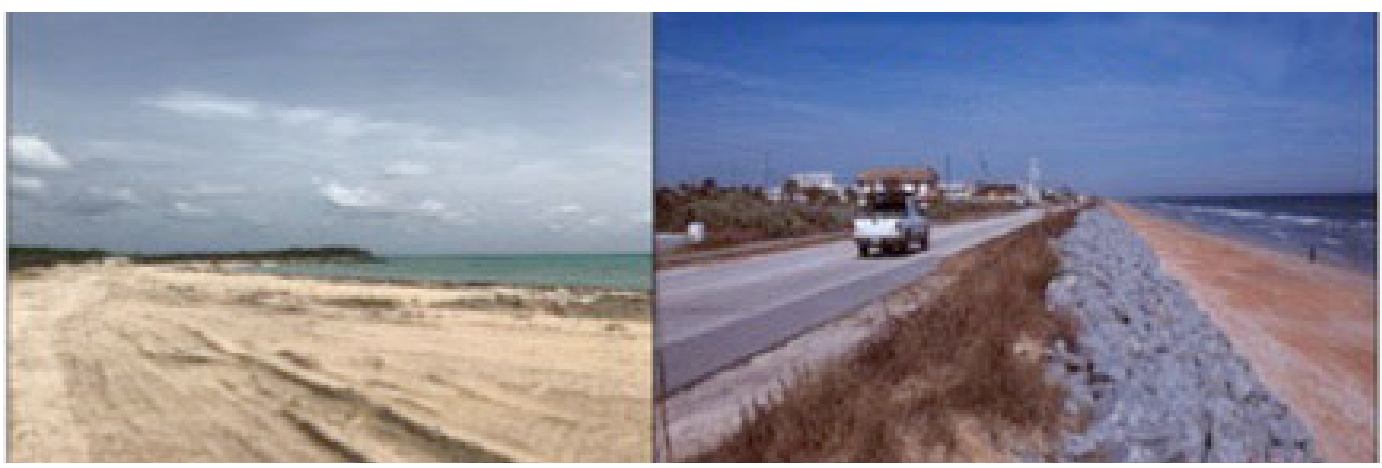

Source: The assessment team, 2017: Pilebuck, 2017

Other examples of robust and resilient design failures and successes were assessed in Ragged Island. There, the storm surge completely devastated the airport terminal. This situation contrasts with the robust design of the US Coast Guard Aviation Facility in Great Inagua (Image 18). By using resilient designs and adequate construction materials the probability of damage of these important and strategic assets can be considerably reduced.

Resilient design should be the focus for stakeholders in the archipelago. Fortunately, there is some improvement in this regard. The best example is the robust design in Great Inagua's Matthew Town Dock currently under construction. This structure withstood the winds and storm surge effects of Hurricane Irma.

Seawalls are also important assets in the infrastructure sector. As a result of Hurricane Irma, several areas of the shoreline seawall in Acklins and Great Inagua were impacted, damaging other structures and properties in the community. Some of these areas were in the process of recovery from the effects of Hurricane Mathew, and because its location is isolated, no resilient design was being deployed. A cost-effective and sustainable solution for this and other similar cases should be incorporated. A seawall could help protect the populated areas, docks, fishing and other commercial and industrial facilities.

Image 19- Airport infrastructure: inadequate vs. resilient design

Ragged Island Airport Terminal

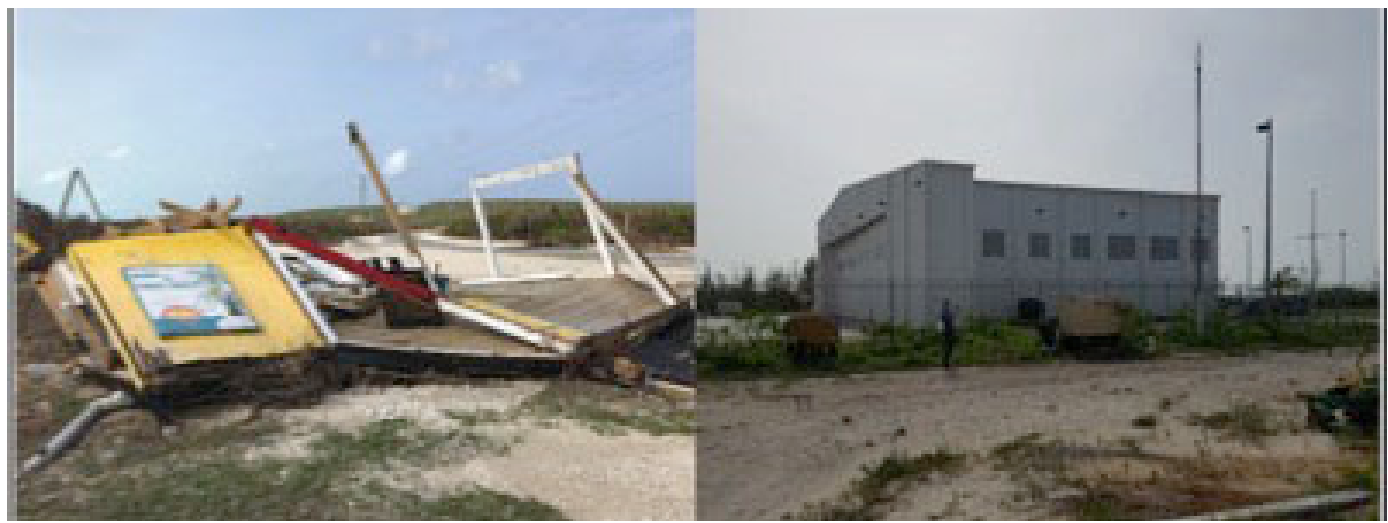

Source: The assessment team, 2017: Pilebuck, 2017 


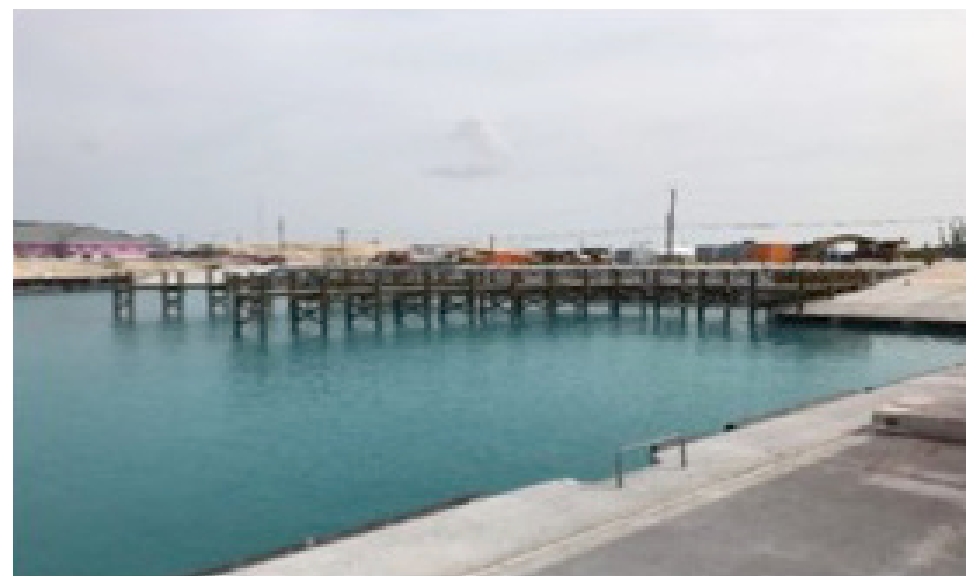

Source: Assessment team, 2017.

\section{Infrastructure: Water}

It is crucial that in islands with distant communities, such as Inagua, the system does not rely exclusively in a central plant. It is recommended to locate contingent infrastructure such as tank capacity and pumps close to them so in the event that the main facility is damaged those communities can reestablish their service.

\section{Productive: Agriculture and Fisheries}

Hurricane Irma should be seen as an opportunity to assess the number of fisherman and vessels operating in the affected areas. Therefore, the design of a plan for the operations of the fisheries subsector is highly encouraged. Similar to other subsectors, it is imperative to ensure that every new infrastructure in the fisheries subsector is built up to code. In addition, since fisheries subsector is a productive activity that supports many families, it is of great importance to avoid the leak of workforce. In some communities, labor will be redirected to the reconstruction effort in detriment of the fishing activity. Therefore, it is important to promptly reconstruct the connected infrastructure to allow for a rapid recovery of the activity. This should not be done at the cost of reconstructing with lower standards.

Likewise, the reconstruction of the agriculture infrastructure should follow standards and codes. New greenhouses should favor structures and materials that are more resistant to wind damage. Finally, an assessment of the damaged fields and an evaluation of the suitability of their locations should be deployed.

\section{Social: Education}

The Ministry of Education should continue to place emphasis on its policy of not utilizing schools as shelters, as this can delay the process of returning schools to their regular schedule. Regarding new infrastructure, all schools being repaired, renovated or built on the family islands should include insect 
screens as a standard. Shorter trees and shrubs should be preferred when the need arises for vegetation on or around campuses.

In Salina Point, Acklins, the foundation for a new school has been laid, but long abandoned. This foundation is on high ground above the town and well out of the way of storm surge. Officials should consider completion of the school at this location, as part of a broader effort to move the town to a safer upland location.

\section{Social: Affected population}

During the field visits, it was possible to notice that, in some cases, there was no particular protocol applied to shelters in relation to the treatment of people with some type of disability. It is advisable to develop a technical standard for the provision of care services for people with disabilities. This regulation should consider adequate standards in relation to infrastructure, space organization, staff and protocols in case of additional emergency and risk. Regarding the latter, aspects related to the ability to prevent danger, minimize risks and emergency responsiveness should be established. Minimum safety measures should be defined; for example:

i) Consider that persons with disabilities may require the accompaniment of a family member;

ii) Prioritize the evacuation of persons with disabilities;

iii) Shelters must be adequate to receive persons with disabilities -including both means of access and appropriately-equipped restroom facilitates; and

iv) Use internal signage for evacuation and identification of shelters.

A review on regional and international best practices on the assistance of persons with disabilities in disaster situations is highly encouraged. For example, Ecuador has developed a set of protocols that could be learned from. 




\section{References}

CDEMA, Caribbean Disaster Emergency Management Agency. Hurricane Irma - Situation Report \# 6. St. Michael. 2017

ECLAC-IDB-PAHO (Inter-American Development Bank and Economic Commission for Latin America and the Caribbean) (2015). "Assessment of the Effects and Impacts Caused by Hurricane Joaquin: The Bahamas".

ECLAC-IDB- PAHO (Inter-American Development Bank and Economic Commission for Latin America and the Caribbean) (2016). "Assessment of the Effects and Impacts Caused by Hurricane Matthew: The Bahamas".

Government of The Bahamas - Bahamas Information Services. Press Release: Early Evacuation Helped Save "A Generation of Ragged Islanders". Nassau - The Bahamas. 2017

NEMA, The National Emergency Management Agency. Aler \# 9. Nassau - The Bahamas. 2017

NHC (National Hurricane Center) (2015). "Tropical Cyclone Report: Hurricane Joaquin". 12 January 2016. [Online] http://wwww.nhc.noaa.gov/data/tcr/AL112015_Joaquin.pdf

NHC (National Hurricane Center) (2015). (2016). "Tropical Cyclone Report: Hurricane Matthew". 7 April 2017. [Online] http://wwww.nhc.noaa.gov/data/tcr/AL112015_Joaquin.pdf

NHC, National Hurricane Center - National Oceanic and Atmospheric Administration. Hurricane Irma Advisor Number 22. Miami - Florida. 2017

NHC, National Hurricane Center - National Oceanic and Atmospheric Administration. Hurricane Irma Advisor Number 22 - Update. Miami - Florida. 2017

NHC, National Hurricane Center - National Oceanic and Atmospheric Administration. Hurricane Irma Advisor Number 26. Miami - Florida. 2017

WTTC (World Travel and Tourism Council) (2017). "Travel and Tourism Economic Impact 2017: Bahamas": [Online] https://www.wttc.org/-/media/files/reports/economic-impact-research/countries-2017/bahamas2017.pdf

Department of Statistics, Ministry of Finance. 2010 Census of Population and Housing Reports. Ministry. The Bahamas 2010.

Ministry of Social Services, Department of Social Services. Report of Shelters in New Providence and Family Islands. Nassau - The Bahamas. October 2017.

NEMA, The National Emergency Management Agency. Bahamas Air Evacuation Report - Hurricane Irma 2017. Nassau - The Bahamas. 2017

Food and Agriculture Organization of the United Nations/Department of Marine Resources Nassau, 2016. The Bahamas, Fisheries and Aquaculture in The Bahamas: A Review 

Copyright ( 2020 United Nations and Inter-American Development Bank. This work is licensed under a Creative Commons IGO 3.0 Attribution-NonCommercial-ShreAlike (CCIGO 3.0 BY-NC-SA) license (http://creativecommons.org/licenses/by-nc-nd/3.0/igo/ legalcode) and may be reproduced with attribution to the IDB and for any non-commercial purpose in its original or in any derivative form, provided that the derivative work is licensed under the same terms as the original. ECLAC and the IDB are not liable for any errors or omissions contained in derivative works and does not guarantee that such derivative works will not infringe the rights of third parties.

Any dispute related to the use of the works of ECLAC and the IDB that cannot be settled amicably shall be submitted to arbitration pursuant to the UNCITRAL rules. The use of IDB's and ECLAC's names for any purpose other than for attribution, and the use of IDB's and ECLAC's logo shall be subject to a separate written license agreement between the IDB and the user and is not authorized as part of this CC-IGO license.

Note that link provided above includes additional terms and conditions of the license.

The opinions expressed in this publication are those of the authors and do not necessarily reflect the views of ECLAC, the Inter-American Development Bank, its Board of Directors, or the countries they represent.

ECLAC Reference Number: LC/TS.2020/30

\section{(c) $(1)$}


Assessment of the Effects and impacts Caused by Hurricane Irma The Bahamas

2017

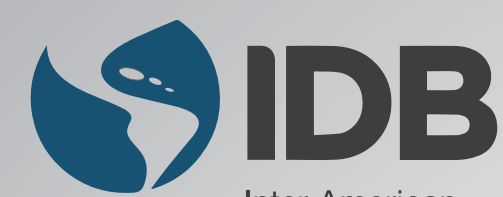

Inter-American

Development Bank

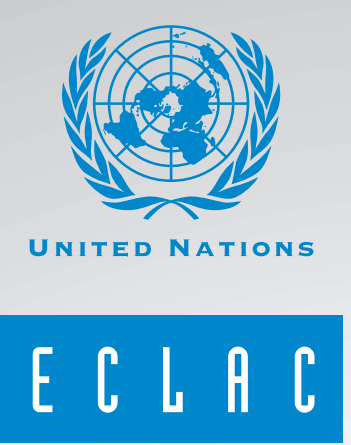

